\title{
OTIMIZAÇÃO DA VIDA ÚTIL DA TILÁPIA CULTIVADA (Oreochromis niloticus), MINIMAMENTE PROCESSADA E ARMAZENADA SOB REFRIGERAÇÃO
}

\author{
MARCILENE CAMILO HEIDMANN SOCCOL
}

Dissertação apresentada à Escola Superior de Agricultura "Luiz de Queiroz", Universidade de São Paulo, para obtenção do título de Mestre em Ciências, Área de Concentração: Ciência e Tecnologia de Alimentos.

P I R A C I C A B A

Estado de São Paulo - Brasil

Dezembro - 2002 


\section{OTIMIZAÇÃO DA VIDA ÚTIL DA TILÁPIA CULTIVADA (Oreochromis niloticus), MINIMAMENTE PROCESSADA E ARMAZENADA SOB REFRIGERAÇÃO}

\section{MARCILENE CAMILO HEIDMANN SOCCOL}

Engenheiro Agrônomo

Orientadora: Prof ${ }^{\mathfrak{a}}$. Dr ${ }^{\mathrm{a}}$. MARÍLIA OETTERER

Dissertação apresentada à Escola Superior de Agricultura "Luiz de Queiroz", Universidade de São Paulo, para obtenção do título de Mestre em Ciências, Área de Concentração: Ciência e Tecnologia de Alimentos.

P I R A C I C A B A

Estado de São Paulo - Brasil

Dezembro - 2002 


\section{Dados Internacionais de Catalogação na Publicação (CIP) DIVISÃO DE BIBLIOTECA E DOCUMENTAÇÃO - ESALQ/USP}

\section{Soccol, Marcilene Camilo Heidmann}

O timiza ção da vida útil da tilá pia cultivada (Oreochromis nilotic us), minimamente processa da e a rmazenada sob refrigeração / Marcilene Camilo Heid mann Soc col. - - Pira cic aba, 2002.

124 p. : il.

Dissertação (mestra do) - - Escola Superior de Agric ultura Luiz de Queiroz, 2002.

Bibliografia.

1. Ácido acético 2. Alimentos de conveniência 3. Alimento processado 4. Amazenamento em a tmosfera modificada 5. Embalagem de alimento 7. Pescado 8. Tilápia I. Título

CDD 664.94028 
Aos meus pais Augustinho e Constância, pela vida, incentivo e carinho Aos meus irmãos, Patrícia e Dione pelo apoio e incentivo

\section{OFEREÇO}




\section{AGRADECIMENTOS}

A Deus, pela minha existência.

À minha orientadora Prof $\stackrel{a}{\text {. Dr }} r^{\underline{a}}$. Marília Oetterer, pela amizade, orientação e incentivo em todas as atividades relacionadas a este trabalho, que contribuíram muito para meu crescimento profissional.

À Escola Superior de Agricultura “Luiz de Queiroz” (ESALQ/USP), em especial ao Departamento de Agroindústria, Alimentos e Nutrição pela oportunidade para a realização deste trabalho.

À Fundação de Apoio á Pesquisa do Estado de São Paulo (FAPESP) pelo apoio financeiro.

A MACPLASTE, através de seu represente Ariel pela doação das bolsas plásticas de EVOH.

Ao Prof. Dr. Claúdio Rosa Gallo pela colaboração nas análises microbiológicas.

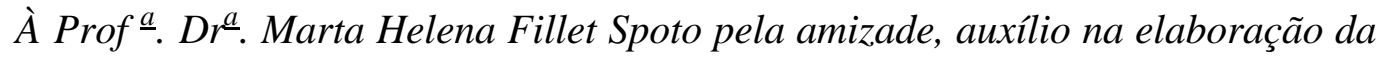
análise sensorial e colaboração na análise de TBARS.

Ao Departamento de Zootecnia, em especial ao Prof. Dr. José Eurico Possebon Cyrino pela permissão do uso de tanques para depuração das tilápias. E aos funcionários, Sérgio e Júnior pelo auxílio no transporte e no processo de depuração dos peixes.

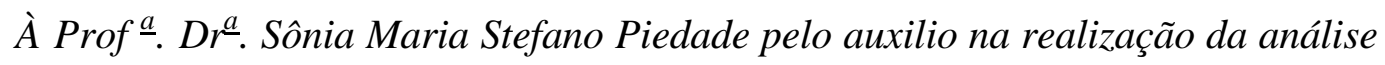
estatística.

À bolsista de Iniciação Científica (CNPq), Denise Oliveira Biato pela amizade e colaboração na realização das análises físico-químicas e sensoriais. 
Aos funcionários do Departamento de Agroindústria, Alimentos e Nutrição, do Laboratório de Pescado, Ivani Marchetto Moreno, Juliana Antunes Galvão e Roberta Rizzo Benato pela amizade e auxílio técnico.

As bibliotecárias Midiam Gustinelli e Beatriz Helena Giongo pelo auxílio técnico no decorrer do curso.

A todos os participantes da análise sensorial.

E a todas as pessoas que direta ou indiretamente colaboraram para a realização deste trabalho. 


\section{SUMÁRIO}

Página

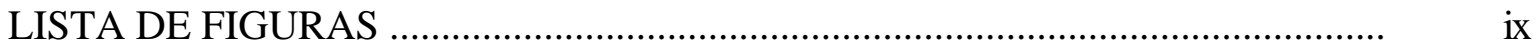

LISTA DE TABELAS ............................................................................ xi

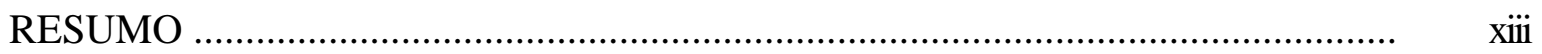

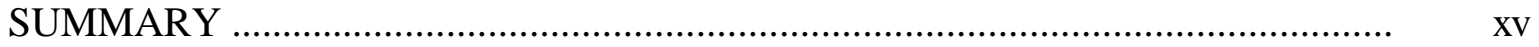

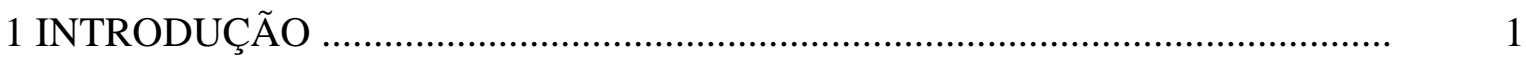

2 REVISÃO DE LITERATURA .................................................................. 3

$2.1 \mathrm{O}$ pescado e o ambiente aquático ...................................................................... 3

2.2 Depuração do pescado e qualidade da carne ................................................ 5

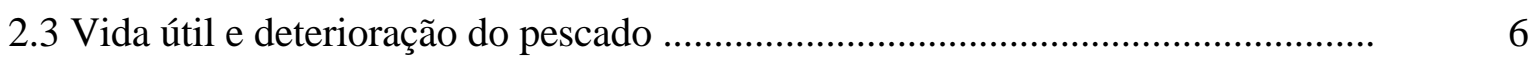

2.4 Embalagens e processos combinados .......................................................... 8

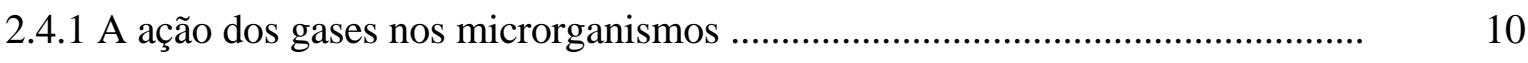

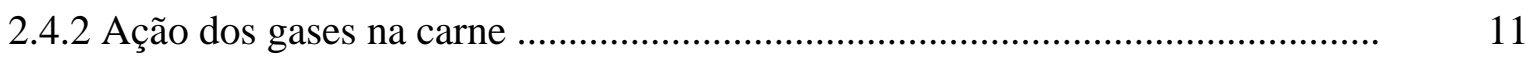

2.4.3 Proporção dos gases e a relação com tempo e temperatura ................................. 13

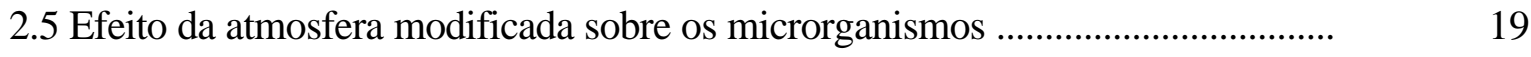

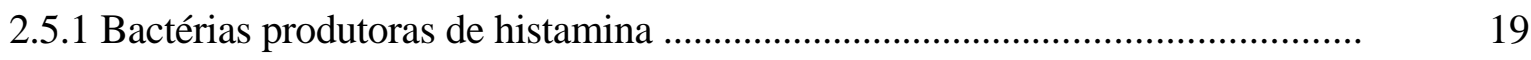

2.5.2 Pseudomonas, Lactobacillus, Alteromonas, Micrococcus, Moraxella e Achromobacter .................................................................................... 20

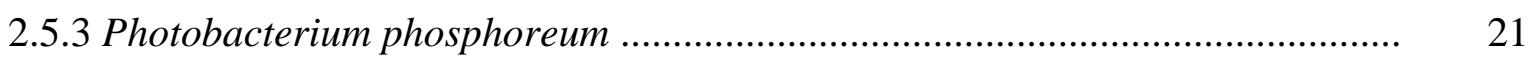

2.5.4 Shewanella, Vibrio, Brochothrix, Yersinia e Bacillus cereus ......................... 22

2.5.5 Aeromonas, Listeria e Escherichia coli .................................................... 23

2.5.6 Clostridium botulinum ......................................................................... 25

2.6 Utilização de ácidos orgânicos na conservação de alimentos ............................... 27

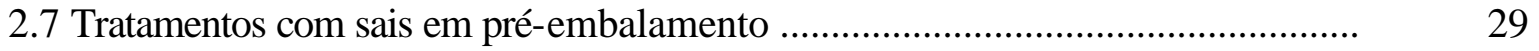




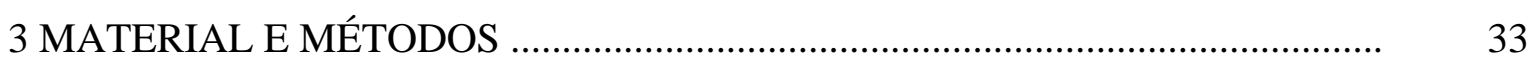

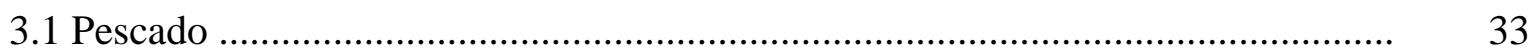

3.2 Metodologia de obtenção e análise dos produtos de pescado minimamente

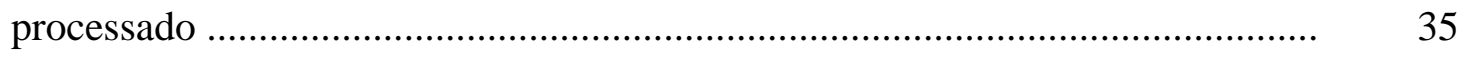

3.3 Tratamento químico dos filés ........................................................................

3.4 Montagem dos produtos nas embalagens ......................................................... 36

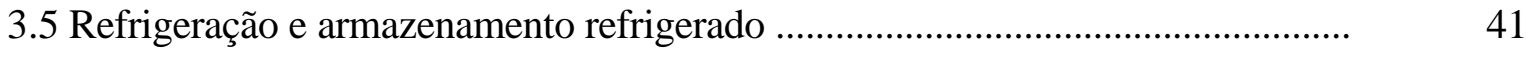

3.6 Análises microbiológicas ................................................................................

3.6.1 Clostridium sulfito-redutores ....................................................................... 41

3.6.2 Coliformes totais e Escherichia coli ...............................................................

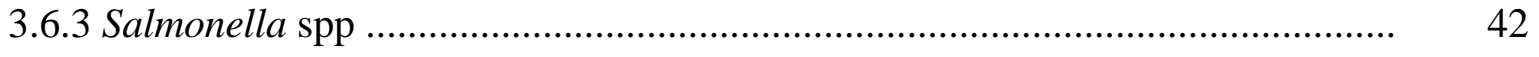

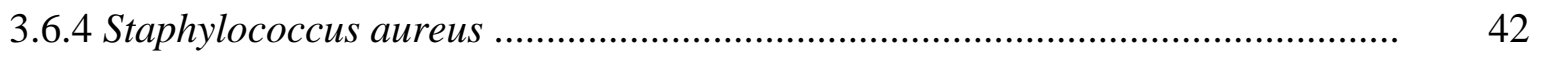

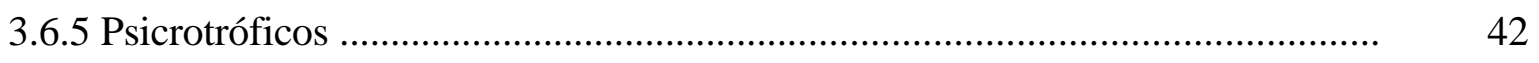

3.6.6 Coliformes totais e Escherichia coli em água ................................................... 43

3.7 Análises físico-químicas ..................................................................................

3.7.1 Composição centesimal ....................................................................................

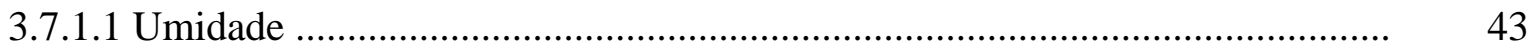

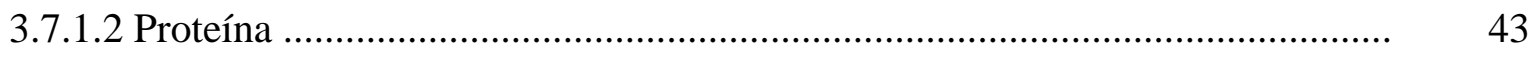

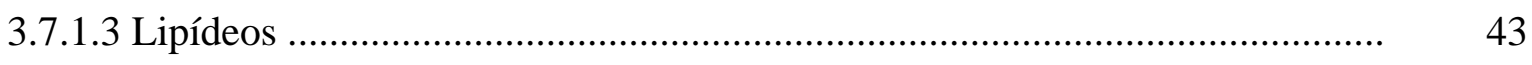

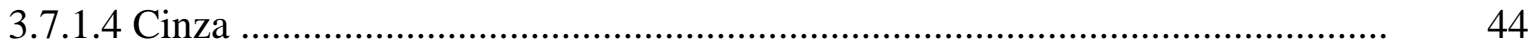

3.7.2 Nitrogênio não protéico (NNP) …………………………………………....

3.7.3 Bases nitrogenadas voláteis totais (BNVT) .........................................................

3.7.4 Determinação da reação do ácido tiobarbitúrico (TBARS) ……………………...

3.7.5 Determinação de $\mathrm{pH}$....................................................................................

3.7.6 Determinação de $\mathrm{pH}$ da água ...........................................................................

3.7.7 Determinação da condutividade elétrica da água .................................................

3.7.8 Determinação de aminoácidos totais ................................................................

3.7.9 Determinação de ácidos graxos ..................................................................... 45

3.8 Análise sensorial.....................................................................................

3.9 Acompanhamento do processamento e análise estatística ...................................... $\quad 45$ 
4 RESULTADOS E DISCUSSÃO .....................................................................

4.1 Análises físico-químicas .............................................................................

4.1.1 Composição centesimal ............................................................................

4.1.1.1 Umidade ............................................................................................ 48

4.1.1.2 Proteína ....................................................................................

4.1.1.3 Lipídeos ............................................................................................ 51

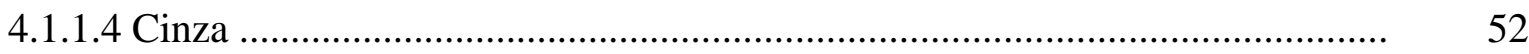

4.1.2 Nitrogênio não protéico - NNP .................................................................... 53

4.1.3 Bases nitrogenadas voláteis totais - BNVT ....................................................... 56

4.1.4 Reações do ácido tiobarbitúrico -TBARS .......................................................... 60

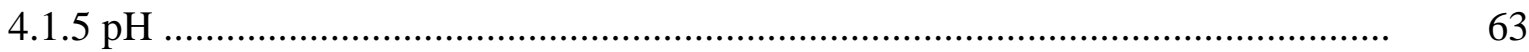

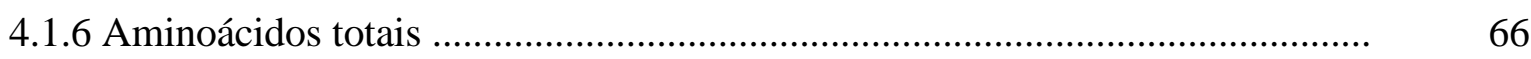

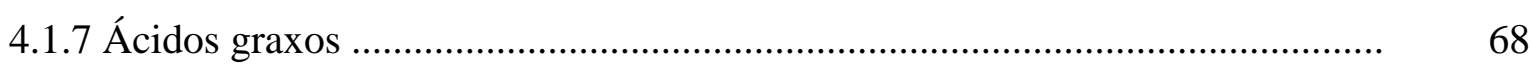

4.2 Análises microbiológicas ..................................................................................

4.2.1 Análise da água de cultivo .........................................................................

4.2.2 Avaliação da qualidade da água de depuração de tilápias ....................................

4.2.3 Coliformes totais e E. coli ........................................................................

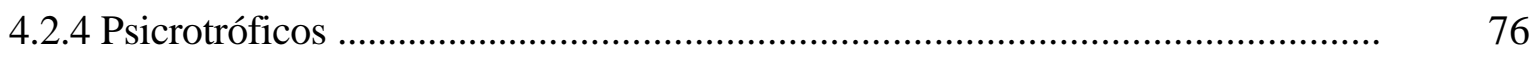

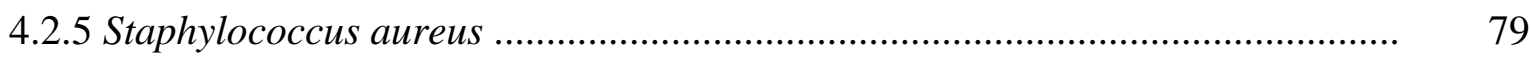

4.2.6 Salmonella spp e Clostridium sulfito-redutores ............................................... $\quad 80$

4.3 Análise sensorial ...........................................................................................

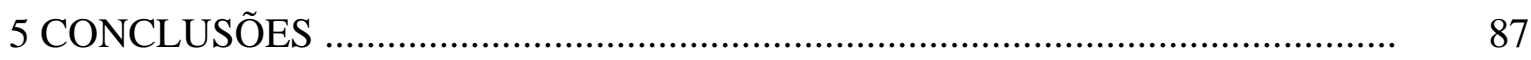

REFERÊNCIAS BIBLIOGRÁFICAS _.................................................................. 89 


\section{LISTA DE FIGURAS}

Página

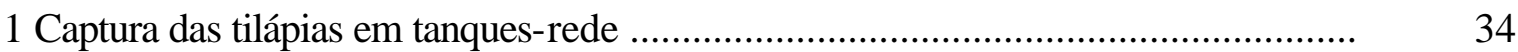

2 Transferência das tilápias para a depuração em tanque com água corrente ............. 34

3 Fluxograma de obtenção e análise do pescado minimamente processado ...............

4 Tilápias dispostas em caixas com gelo (a); retirada da pele (b); filetagem (c) e (d); filés dispostos em bandejas com gelo (e); filés imersos em solução de ácido acético a 1\% (f) ................................................................................... 36

5 Selamento térmico da embalagem sob ar atmosférico (controle) (a); evacuação do ar na embalagem (b); injeção da mistura gasosa na embalagem (c)

6 Filés de tilápia in natura, refrigerados e embalados em bandejas de poliestireno e filme plástico de EVOH .......................................................................................... 38

7 Filés de tilápia in natura, refrigerados e embalados sob atmosfera modificada ..... 38

8 Filés de tilápia in natura, refrigerados e embalados a vácuo ....................................

9 Filés de tilápia in natura, acidificados, refrigerados e embalados em bandeja de poliestireno e filme plástico de EVOH ……………………………………….....

10 Filés de tilápia in natura, acidificados, refrigerados e embalados sob atmosfera

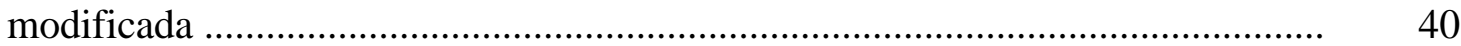

11 Filés de tilápia in natura, acidificados, refrigerados e embalados a vácuo ............ 40

12 Ficha de avaliação sensorial das amostras de filés de tilápia ...................................

13 Disposição das amostras em cabines sensoriais .......................................................

14 Umidade em filés de tilápia mantidos sob refrigeração a $1 \pm 1^{\circ} \mathrm{C}$, durante

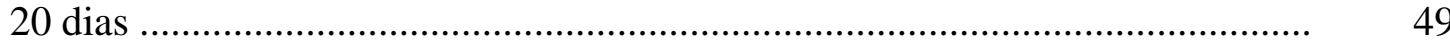

15 Proteína em filés de tilápia mantidos sob refrigeração a $1 \pm 1^{\circ} \mathrm{C}$, durante 20 dias 
16 Lipídeos em filés de tilápia mantidos sob refrigeração a $1 \pm 1^{\circ} \mathrm{C}$, durante 20 dias 52

17 Cinza em filés de tilápia mantidos sob refrigeração a $1 \pm 1^{\circ} \mathrm{C}$, durante 20 dias .... 53

18 Nitrogênio não protéico em filés de tilápia mantidos sob refrigeração a $1 \pm 1^{\circ} \mathrm{C}$,

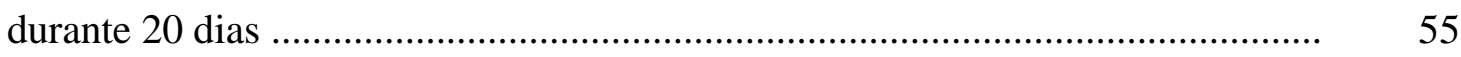

19 Bases nitrogenadas voláteis totais em filés de tilápia mantidos sob refrigeração a $1 \pm 1^{\circ} \mathrm{C}$, durante 20 dias ..................................................................... 58

20 Ácido tiobarbitúrico em filés de tilápia mantidos sob refrigeração a $1 \pm 1^{\circ} \mathrm{C}$,

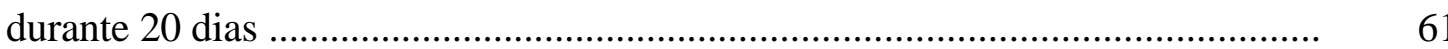

21 Valores de $\mathrm{pH}$ em filés de tilápia mantidos sob refrigeração a $1 \pm 1^{\circ} \mathrm{C}$, durante 20 dias

22 Bactérias psicrotróficas (log UFC/g) em filés de tilápia mantidos sob refrigeração a $1 \pm 1{ }^{\circ} \mathrm{C}$, durante 20 dias

23 Cor em filés de tilápia mantidos sob refrigeração a $1 \pm 1^{\circ} \mathrm{C}$, durante 20 dias .......

24 Aroma em filés de tilápia mantidos sob refrigeração a $1 \pm 1^{\circ} \mathrm{C}$, durante 20 dias ..

25 Textura em filés de tilápia mantidos sob refrigeração a $1 \pm 1^{\circ} \mathrm{C}$, durante 20 dias

26 Aparência em filés de tilápia mantidos sob refrigeração a $1 \pm 1^{\circ} \mathrm{C}$, durante 20 dias 


\section{LISTA DE TABELAS}

Página

1 Umidade $(\mathrm{g} / 100 \mathrm{~g})$ em filés de tilápia mantidos sob refrigeração a $1 \pm 1^{\circ} \mathrm{C}$,

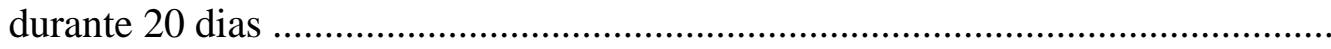

2 Proteína $(\mathrm{g} / 100 \mathrm{~g})$ em filés de tilápia mantidos sob refrigeração a $1 \pm 1{ }^{\circ} \mathrm{C}$, durante 20 dias

3 Lipídeos $(\mathrm{g} / 100 \mathrm{~g})$ em filés de tilápia mantidos sob refrigeração a $1 \pm 1{ }^{\circ} \mathrm{C}$, durante 20 dias

4 Cinza $(\mathrm{g} / 100 \mathrm{~g})$ em filés de tilápia mantidos sob refrigeração a $1 \pm 1{ }^{\circ} \mathrm{C}$, durante 20 dias

5 Nitrogênio não protéico $(\mathrm{mg} / 100 \mathrm{~g})$ em filés de tilápia mantidos sob refrigeração a $1 \pm 1^{\circ} \mathrm{C}$, durante 20 dias

6 Bases nitrogenadas voláteis totais $(\mathrm{mg} / 100 \mathrm{~g})$ em filés de tilápia mantidos sob refrigeração a $1 \pm 1^{\circ} \mathrm{C}$, durante 20 dias

7 Ácido tiobarbitúrico (mg MA/kg) em filés de tilápia mantidos sob refrigeração a $1 \pm 1^{\circ} \mathrm{C}$, durante 20 dias

8 Valores de $\mathrm{pH}$ em filés de tilápia mantidos sob refrigeração a $1 \pm 1{ }^{\circ} \mathrm{C}$, durante 20 dias

9 Aminoácidos totais $(\mathrm{g} / 100 \mathrm{~g}$ em matéria seca) em filés de tilápia mantidos sob refrigeração a $1 \pm 1^{\circ} \mathrm{C}$, durante 20 dias

10 Ácidos graxos (g/100g em matéria seca) em filés de tilápia mantidos sob refrigeração a $1 \pm 1^{\circ} \mathrm{C}$, durante 20 dias 
$12 \mathrm{NMP} / 100 \mathrm{~mL}$ de coliformes totais, E. coli e características físico-químicas da água de depuração das tilápias

$13 \mathrm{NMP} / \mathrm{g}$ de coliformes totais em filés de tilápia mantidos sob refrigeração a $1 \pm 1^{\circ} \mathrm{C}$, durante 20 dias

14 Bactérias psicrotróficas (UFC/g) em filés de tilápia mantidos sob refrigeração a $1 \pm 1^{\circ} \mathrm{C}$, durante 20 dias

15 Staphylococcus aureus em filés de tilápia mantidos sob refrigeração a $1 \pm 1{ }^{\circ} \mathrm{C}$, durante 20 dias

16 Cor, aroma, textura e aparência em filés de tilápia mantidos sob refrigeração a $1 \pm 1^{\circ} \mathrm{C}$, durante 20 dias - notas (médias) atribuídas pela equipe sensorial ........... 


\title{
OTIMIZAÇÃO DA VIDA ÚTIL DA TILÁPIA CULTIVADA (Oreochromis niloticus), MINIMAMENTE PROCESSADA E ARMAZENADA SOB REFRIGERAÇÃO
}

\author{
Autora: MARCILENE CAMILO HEIDMANN SOCCOL \\ Orientadora: Prof ${ }^{\mathrm{a}}$. Dr ${ }^{\mathrm{a}}$. MARÍLIA OETTERER
}

\section{RESUMO}

A efetiva consolidação da piscicultura depende do escoamento da produção, que por sua vez depende da demanda. Para que o consumo de pescado no Brasil seja ampliado, é necessário que haja oferta de produtos com a qualidade exigida pelo consumidor. Esta pesquisa teve como objetivo a obtenção de um novo produto, tipo alimento de conveniência - tilápia minimamente processada, estabelecendo a vida útil deste, por monitoramento dos componentes físico-químicos e avaliação sensorial e microbiológica. Foram utilizados peixes provenientes de áreas de cultivo do Estado de São Paulo, da região de Jaú, da espécie tilápia do Nilo, Oreochromis niloticus, os quais foram submetidos à depuração, eviscerados, filetados, acondicionados em bandejas de poliestireno e recobertos com filmes plásticos de etileno-álcool-vinílico - EVOH (controle); também foi feito o embalamento sob atmosfera modificada - EAM $\left(60 \% \mathrm{CO}_{2}+40 \% \mathrm{O}_{2}\right)$ e a vácuo. Parte dos peixes foi submetida ao tratamento químico, por imersão em ácido acético a 1\%. As amostras embaladas foram mantidas sob refrigeração, na faixa de $1 \pm 1^{\circ} \mathrm{C}$, quando foram submetidas às análises, no $1^{\circ}$ dia de experimento e aos 7, 13 e 20 dias de armazenamento refrigerado. Os tratamentos aplicados não apresentaram diferenças significativas para composição centesimal, 
nitrogênio não protéico - NNP, bases nitrogenadas voláteis totais - BNVT e pH. A EAM associada ou não ao ácido acético apresentou valores mais elevados de TBA (ácido tiobarbitúrico), sendo detectada a presença de ranço pelos provadores, integrantes da equipe de análise sensorial. Os filés tratados com ácido acético apresentaram-se descoloridos e com textura menos firme, em relação aos demais tratamentos. Durante o período de armazenamento não detectou-se a presença de Salmonella, Clostridium sulfito-redutores e E. coli. Os tratamentos embalados em EAM e a vácuo, associados ou não ao ácido acético, inibiram o desenvolvimento de $S$. aureus, coliformes totais e psicrotróficos proporcionando uma vida útil de 20 dias. $\mathrm{O}$ embalamento a vácuo associado ao ácido acético foi o tratamento que manteve as características físicoquímicas, microbiológicas e sensoriais mais estáveis até o término do experimento. 


\title{
OPTIMIZING THE SHELF-LIFE OF MINIMALLY PROCESSED AQUACULTURED TILAPIA (Oreochromis niloticus) STORED UNDER REFRIGERATION
}

\author{
Author: MARCILENE CAMILO HEIDMANN SOCCOL \\ Adviser: Prof ${ }^{\mathrm{a}}$. Dr ${ }^{\mathrm{a}}$. MARÍLIA OETTERER
}

\section{SUMMARY}

The effective aquaculture consolidation depends on the production sale, which in the other hand, depends on the demand. In order to increase Brazilian fish consumption, it is necessary to offer products with quality demanded by the consumers. The purpose of this research was to obtain a new convenience product - minimally processed tilapia. The shelf-life of the product were determining by monitoring physical-chemical components, sensory and microbiological analysis. With this intent, aquacultured Nile tilapia (Oreochromis niloticus) raised in farms located in the Jau region, Sao Paulo State, was depurated, gutted, filleted, packed in polyestirene trays and covered with ethylenevinyl-alcohol $(\mathrm{EVOH})$ plastic films (control). It was also made packing with modified atmosphere (MAP) $60 \% \mathrm{CO}_{2}+40 \% \mathrm{O}_{2}$ and vacuum packing. Part of the fish was chemically treated by immersing in a $1 \%$ acetic acid solution. The packed samples were storage under a temperature which ranged from $1 \pm 1^{\circ} \mathrm{C}$ and had been analyzed at the $1^{\text {st }}$ day of experiment and to the $7^{\text {th }}, 13^{\text {th }}$ and $20^{\text {th }}$ days. No significant differences were verified among treatments for the centesimal composition, non-protein nitrogen (NPN), total volatile bases nitrogen (TVBN) and $\mathrm{pH}$ as well. The use of the MAP, whether associated with acetic acid or not, promoted the TBA (thiobarbituric acid) increasing. It 
was detected rancidity the team responsible for the sensory evaluation. The fillets treated with acetic acid were fainted colors and showed less firm texture, when compared to the non-treated ones. Salmonella, Clostridium sulfite-reducing and E. coli were not detected during the storage period. Treatments using MAP and vacuum packing, whether associated with acetic acid or not, inhibited the development of S. aureus, total coliforms and psychrotrophic, maintaining the shelf life to 20 days. However, the treatment combining vacuum packing and acetic acid maintained the physical-chemical, microbiological and sensory characteristics stabler until the end of the experiment. 


\section{INTRODUÇÃO}

A produção de pescado no Brasil vem crescendo sob o influxo da expansão da piscicultura de água doce e com o potencial de águas interiores. Não se deve estimular a produção do pescado, somente devido ao fato deste alimento se constituir em excelente fonte alimentar, mas também, em fonte de divisas para o país, devido à possibilidade de ser exportado (Oetterer, 1991).

A tilápia do Nilo (Oreochromis niloticus) foi introduzida no Brasil em 1971, e é hoje popular no Nordeste onde são capturadas, anualmente, cerca 4500 t nos açudes (Lovshin \& Cyrino, 1998). A produção de tilápias em cultivos semi-intensivos e intensivos foi de 35000 t, em 1998, sendo assim, a espécie de pescado de água doce mais cultivada no Brasil (BRASIL, 2002a).

O potencial piscícola da tilápia para pequenos criadores se deve ao fato desta espécie ser resistente ao manuseio e transporte, de arraçoamento fácil e econômico, crescimento rápido e resistente a baixas concentrações de oxigênio dissolvido, além de apresentar carne de sabor apreciado e com poucas espinhas (Freitas \& Gurgel, 1984).

Segundo Lovshin \& Cyrino (1998) o Brasil tem potencial para se tornar o maior produtor de pescado cultivado do mundo. Os autores justificaram esta afirmativa, citando a água disponível para cultivo, a disponibilidade de grãos para produção de rações, o clima tropical e o fato de haver no Brasil a maior e mais diversificada fauna de água doce do mundo, com poucas espécies testadas quanto à viabilidade para o cultivo. A forma dominante de cultivo deverá ser o intensivo, em tanque-rede, que permite a utilização de grande quantidade de água para liberação de efluentes e pode atender às unidades processadoras e supermercados.

Objetivando oferecer subsídios para agilizar a transferência da tecnologia gerada 
na universidade ao setor produtivo, Oetterer (1999) apresentou as possibilidades para processamento do pescado cultivado, nas formas de refrigerado, congelado, defumado/refrigerado e minced, com os respectivos custos fixos e variáveis, bem como o fluxo e layout para implantação de usinas beneficiadoras.

Ao se imaginar um produto beneficiado de pescado para chegar ao consumidor e ser bem recebido por este, deve-se tentar contornar os problemas ligados à falta de higiene e qualidade na comercialização in natura, que ocorrem com o pescado marinho; assim, o pescado refrigerado pode ser definido como um produto minimamente processado, com uma vida útil aproximada de 12 dias sob refrigeração, não apresentando riscos de ordem higiênica, desde que embalado convenientemente (Oetterer, 1999).

A partir da década de 90, com a globalização, houve uma demanda crescente para o consumo de alimentos frescos, nutritivos e com aparência mais próxima aos naturais, porém sem os efeitos indesejáveis das alterações físico-químicas ou microbiológicas e com a segurança garantida; portanto, é necessário, que se utilize processos combinados, de tal forma que se exponha o mínimo possível o produto a condições adversas, ou seja, produtos minimamente processados (Vitali, 1997).

$\mathrm{O}$ objetivo desta pesquisa foi obter um novo produto, tipo alimento de conveniência - tilápia minimamente processada, estabelecendo a vida útil deste, por monitoramento dos componentes físico-químicos e avaliação microbiológica e sensorial. Para tal, estabeleceu-se uma diretriz para os procedimentos pré e pós captura, como o monitoramento da água de proveniência e os tratamentos com ácidos orgânicos, embalamento sob atmosfera modificada e a vácuo, respectivamente. 


\section{REVISÃO DE LITERATURA}

\subsection{O pescado e o ambiente aquático}

Uma vantagem da aqüicultura de peixes de água doce em relação à marítima é a possibilidade de ser feito o monitoramento da água de criação e assim se poder contar com a água livre de contaminação, por exemplo, Vibrio cholerae, metais pesados, pesticidas e outros contaminantes (Antunes, 1997).

Kitahara et al. (2000) evidenciam que várias espécies de peixes de água doce, procedentes da Amazônia brasileira, dentre elas a tilápia (Tilapia spp), não apresentam níveis de mercúrio total acima dos limites de tolerância brasileiros, ficando entre 0,01 e $0,14 \mathrm{mg} \mathrm{Hg} / \mathrm{kg}$ para as espécies não carnívoras.

Mantovani et al. (2000) analisaram espécies de pescado, carpa (Cyprinus carpio), pacu (Piaractus mesopatamicus) e tilápia (Tilapia spp) procedentes de piscicultores e pesque-pagues das regiões do Vale do Ribeira, Vale do Paraíba e Vale do Paranapanema, no Estado de São Paulo, e encontraram níveis abaixo dos limites estabelecidos como problemáticos pela legislação brasileira para cádmio, chumbo, crômio, cobre, níquel e zinco.

Em tilápias do Nilo (Oreochromis niloticus) capturadas nos açudes do Nordeste, particularmente no açude Araras, em Reriutaba, Ceará, Freitas \& Gurgel (1984) avaliaram o grau de frescor, segundo as normas estabelecidas pela legislação brasileira e estabeleceram 12 dias como limite de vida útil para as tilápias íntegras e 21 dias para as evisceradas, ambas mantidas sob gelo.

Os microrganismos se encontram no intestino, guelras e sob a pele dos peixes. Ward (1994) afirma que os baixos índices de contaminantes encontrados nas guelras e na pele são comumente associados às águas limpas e frias, e os índices mais elevados às 
águas tropicais, subtropicais e áreas poluídas. No intestino de peixes alimentados, o índice de microrgamismos contaminantes é alto.

A flora bacteriana dos peixes de água fria é dominada pelo gênero psicrotrófico Gram-negativo, sendo que os Gram-positivos dominam a flora bacteriana de peixes de águas tropicais (Shewan, 1977).

O pescado fresco é normalmente considerado um alimento seguro, embora possa ser um veículo importante para as intoxicações alimentares de origem bacteriana (Shewan, 1962).

Germano et al. (1998) alertaram para os problemas com o consumo de pescado, quanto ao fato deste alimento poder ser veiculador de microrganismos patogênicos para o ser humano, a maior parte deles fruto da contaminação ambiental, a destacar os do gênero Vibrio. O V. parahaemolyticus tem causado gastrenterite aguda, caracterizada por quadro disentérico, principalmente após o consumo de peixe, camarões e ostras in natura. $\mathrm{O}$ V. cholerae de origem humana atinge as águas do mar, rios e lagos através do despejo de esgotos e pode levar à mortandade da população acometida. Merecem destaque as bactérias do gênero Salmonella, tanto as de origem humana, S. typhi e $S$. paratyphi, quanto as de origem animal, bem como as Shiguella spp, todas encontradas em águas poluídas por esgotos ou excretas de animais. Como consequiência direta da manipulação inadequada, são apontados os Streptococcus sp e o Staphylococcus aureus, ambos de origem humana, encontrados nas mucosas e superfície da pele, e que encontram no pescado o ambiente favorável para sua multiplicação. Outros agentes bacterianos podem contaminar o pescado e causar riscos à saúde, como as cepas psicrotróficas de Bacillus cereus que podem produzir enterotoxina nos alimentos elaborados a base de peixe, sobretudo os com $\mathrm{pH}$ superior a 6,0, acarretando surtos caracterizados por diarréia.

Oetterer (1991) relatou que devido à presença de proteínas de alto valor biológico, associadas à alta atividade de água, o músculo do pescado está propício ao desenvolvimento microbiano, assim como a existência de substâncias nitrogenadas livres que favorecem a deterioração.

Segundo Dodds (1993) o ambiente aquático é frequientemente contaminado com 
esporos de Clostridium botulinum e é esperado que o pescado também o seja. A contaminação do pescado pode ser o resultado da exposição a esporos, antes da captura ou durante o processamento e armazenamento.

$\mathrm{O}$ pescado cultivado em sistema intensivo, geralmente tem controlados os problemas sanitários, se provier de água de boa qualidade; é o caso dos salmões e das trutas nas regiões temperadas, no entanto, se os tanques forem de terra, com pouca movimentação de água, pode ocorrer uma estruturação de cepas não proteolíticas de $C$. botulinum, com conseqüente contaminação em um nível indesejável (International Commission on Microbiological Specifications for Foods - ICMSF, 1997).

\subsection{Depuração do pescado e qualidade da carne}

A deterioração microbiana pode ser melhor controlada em peixes cultivados do que em peixes capturados no mar, pois os primeiros, se mantidos sem alimentação por alguns dias irão apresentar o trato gastrintestinal limpo. A depuração do pescado em água tratada adequadamente reduz a contaminação bacteriana superficial, e poderá conseqüentemente, colaborar para a estabilidade do armazenamento refrigerado (Haard, 1992).

A depuração é um processo que leva à diminuição dos microrganismos e substâncias deletérias. A eficiência desse processo depende do tipo de tanque e tempo de depuração; da temperatura, turbidez, oxigenação, densidade de acondicionamento e salinidade da água; da espécie e condição fisiológica desta; do nível de contaminação inicial e tipo de microrganismo a ser eliminado (José, 1996). Um outro fator importante é a circulação da água do tanque que evita a deposição de produtos fecais eliminados que poderiam recontaminar os peixes, além de resultar na queda dos níveis de oxigênio dissolvido na água (Reilly \& Barile, 1987).

Segundo Oetterer (1999) o período de depuração de peixes recomendado pelos pesquisadores brasileiros é de pelos menos $24 \mathrm{~h}$ sem alimentação, para que as espécies de pescado cultivado que tenham um sabor característico na carne, devido ao tipo de alimentação recebida, possam ter este sabor atenuado.

A depuração de carpas (Cyprinus carpio) acarreta perda de peso do pescado 
devido à diminuição do seu conteúdo gastrintestinal, minimizando a possibilidade de contaminação durante as operações de abate e evisceração. Filés de carpa submetidos à

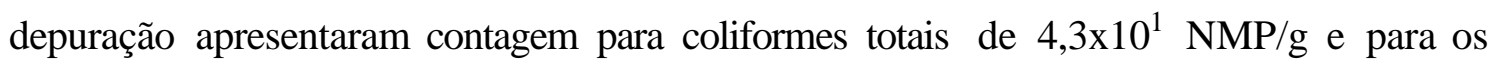
não depurados de 2,3×10 ${ }^{2} \mathrm{NMP} / \mathrm{g}$ (Krolow et al., 2000).

Wesson et al. (1979) estudaram a importância do aroma e textura na aceitabilidade global para uma variedade de produtos comerciais à base de pescado, e concluíram que o aroma foi a característica mais determinante, quando os mesmos apresentavam-se rançosos; quando as amostras apresentavam-se com baixa a moderada rancidez, a textura exercia maior influência na avaliação sensorial.

Sawyer et al. (1988) avaliaram o aroma, textura e a aceitabilidade de filés de "haddock" (Melanogrammus aeglefinus) e bacalhau (Gadus morhua), e concluíram que o aroma foi considerado um critério de qualidade mais importante que a textura. Em outra pesquisa, Hamilton \& Bennett (1983) utilizando diferentes espécies de truta (Salmo spp), também concluíram que o aroma foi o atributo mais importante na determinação da aceitabilidade.

\subsection{Vida útil e deterioração do pescado}

A vida útil de muitos alimentos perecíveis como carnes, ovos e pescado, é limitada pela presença do oxigênio atmosférico, uma vez que nestas condições podem ocorrer reações com o oxigênio, crescimento de microrganismos aeróbios deterioradores e ataque pelos insetos. Cada um destes fatores, ou o conjunto deles resulta na alteração da cor, sabor, odor e a deterioração global da qualidade dos alimentos (Smith et al., 1987).

A vida útil do pescado é determinada pelas reações enzimáticas e pelo número e espécies de microrganismos que determinam a perecibilidade do produto. Outro fator fundamental na vida útil do pescado é a temperatura, que deve ser monitorada nas diversas etapas de obtenção do produto, desde a captura, refrigeração, distribuição, estocagem e temperatura final no varejo (Huss, 1971).

Kirschnik et al. (2000) recomendam o abate da tilápia do Nilo (Oreochromis niloticus) sem estresse, baseados no fato de que a degradação de ATP - Trifosfato de 
Adenosina, medida pela relação ATP/IPM - Monofosfato de Inosina, atinge o valor de 0,893 após $24 \mathrm{~h}$, enquanto que com estresse este mesmo valor ocorre após 10h; o rigormortis pleno em peixes estressados é atingido em $12 \mathrm{~h}$ a $0^{\circ} \mathrm{C}$ e nos não estressados, em $24 h$.

A vida útil da pescadinha (Cynoscion spp) resfriada, armazenada em câmara frigorífica com temperatura entre 6 a $7^{\circ} \mathrm{C}$ e comercializada em mercado de Niterói, RJ foi avaliada aos 4 dias de exposição à venda, por Araújo et al. (2000). Os peixes apresentaram 13,06 mg BNVT/100g (bases nitrogenadas voláteis totais), $\mathrm{pH} \mathrm{6,62} \mathrm{e} \mathrm{1,10}$ mg TMA/100g (trimetilamina), além de serem classificados como de "bom frescor" pela análise sensorial.

A avaliação da peroxidação lipídica foi feita por Luzia et al. (2000) em espécies de pescado, inclusive a tilápia (Oreochromis spp), a fim de verificar a integridade da fração lipídica, recomendada em dietas que buscam os ácidos graxos polinsaturados $\omega$-3. Os autores encontraram valores de TBA (ácido tiobarbitúrico) de 0,235 mg MA/kg (malonaldeído) no verão e $0,117 \mathrm{mg} \mathrm{MA} / \mathrm{kg}$ no inverno, ambos dentro de índices satisfatórios, porém havendo rancidez.

A deterioração natural limita o tempo de vida útil do pescado pós captura. Esta deterioração tem induzido pesquisas, no desenvolvimento de métodos, para retardar o crescimento microbiano, e reduzir a relação de deterioração, através do controle da microbiota.

$\mathrm{O}$ número de bactérias no pescado in natura pode ser diminuído, e a vida útil aumentada, através de uma dvagem de alta pressão com jatos de água ou usando uma solução de cloro cetilpiridio a 0,1\% (Mayer \& Ward, 1991). Também podem ser usados sobre o pescado in natura, o cloro pulverizado, dióxido de cloro ou sorbato de potássio com objetivo de diminuir a contagem bacteriana (Lin et al., 1996; Mayer \& Ward, 1991).

O fator determinante para melhorar a qualidade do pescado capturado é, segundo Braga et al. (2000) proceder a higienização prévia com água tratada; os autores monitoraram a água e os camarões (Xyphopeneaus kroyeri e Penaeus schmitti) avaliando a microbiota associada à superfície destas espécies. 
Kosak \& Toledo (1981) estudaram a combinação de uma solução de cloro (1000 $\mu \mathrm{g} / \mathrm{mL}$ de cloro livre) com embalagem de polietileno e a vácuo, para tainha (Mugil cephalus) armazenada a $-2^{\circ} \mathrm{C}$. Todos os tratamentos apresentaram-se aceitáveis, organolepticamente, até os 14 dias de armazenamento.

Prentice \& Sainz (2000) desenvolveram um produto minimamente processado a base de carpa-capim (Ctenopharyngodon idella) partindo de lavagens dos filés com hipoclorito de sódio e salmoura e embalamento a vácuo, chegando à vida útil de 30 e 60 dias, quando refrigerados a 8 e $2^{\circ} \mathrm{C}$, respectivamente.

\subsection{Embalagens e processos combinados}

A preservação dos alimentos é baseada em métodos combinados, que podem ser aplicados para melhorar os produtos tradicionais, bem como desenvolver novos produtos. Métodos combinados asseguram estabilidade e segurança, resultando em produtos com propriedades sensoriais e nutricionais adequadas (Leistner, 1992).

A maior necessidade por produtos de conveniência, fáceis de preparar, motivada pelo novo estilo de vida e, ainda, a invasão das prateleiras por produtos estrangeiros de alta qualidade e diversificação, vêm modificando o tradicional consumidor de alimentos. E este hoje, passa a se utilizar cada vez mais dos produtos de fácil preparo, higienicamente corretos e vantajosos do ponto vista nutricional (Oetterer, 1999).

A renovação no interesse em aumentar a vida útil do pescado, é devido à demanda crescente do consumo de produtos frescos, que tem conduzido a uma maior diversificação de produtos embalados sob atmosfera modificada, na qual a composição do ar é mudada ou modificada. Esse aumento da vida útil do pescado in natura será muito vantajoso, pois reduzirá o desperdício durante a distribuição e a exposição no varejo, resultando na melhoria da qualidade dos produtos frescos e no abastecimento regular, com preços razoáveis (Lioutas, 1988).

Durante as três últimas décadas houve crescimento da produção de alimentos embalados com gás, no varejo. Este crescimento é resultante dos avanços na indústria de embalagens, que tem levado ao desenvolvimento de polímeros com filmes de alta barreira, e equipamentos de embalagens termomoldadas. As embalagens a gás são uma 
extensão do processo de embalamento a vácuo. A técnica consiste no embalamento dos produtos sob uma atmosfera com vários gases como $\mathrm{CO}_{2}, \mathrm{~N}_{2}$ e $\mathrm{O}_{2}$, sendo o $\mathrm{CO}_{2}$ o mais comumente usado, e possívelmente o mais efetivo, com ou sem a presença de outros gases (Wolfe, 1980).

Há várias formas pelas quais a atmosfera que cerca um produto pode ser modificada, sendo que as mais relevantes para pescado e seus derivados, segundo Silliker \& Wolfe (1980) são as seguintes:

- Embalagens com Atmosfera Modificada - EAM: há substituição do ar da embalagem por um gás ou uma mistura de gases, a qual difere da composição do ar, onde a proporção de cada componente é fixada e a mistura é introduzida, mas nenhum controle adicional é feito durante o período de armazenamento;

- Embalagens a Vácuo: o produto é colocado em uma embalagem com baixa permeabilidade ao oxigênio, o ar é evacuado e a embalagem lacrada. A atmosfera gasosa da embalagem a vácuo é menor $\left(2-5 \% \mathrm{O}_{2}\right)$, e provavelmente é alterada durante o período de armazenamento.

Os três principais gases utilizados, comercialmente, em embalagens sob atmosfera modificada são gás carbônico $\left(\mathrm{CO}_{2}\right)$, nitrogênio $\left(\mathrm{N}_{2}\right)$ e oxigênio $\left(\mathrm{O}_{2}\right)$, cujas

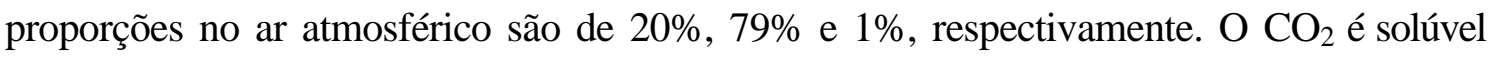
tanto em água como em lipídeos e é o principal responsável pelo efeito bacteriostático visto em embalagens sob atmosfera modificada. $\mathrm{O}$ efeito provocado em microrganismos é a diminuição na taxa de crescimento durante a fase logarítmica (Farber, 1991). Este efeito bacteriostático é influenciado pela concentração de $\mathrm{CO}_{2}$, carga inicial da população bacteriana, temperatura de armazenamento e tipo de produto a ser embalado (Reddy et al., 1992).

Revisões feitas por Wolfe (1980); Daniels et al. (1985); Genigeorgis (1985); Hintlian \& Hotchkiss (1986); Pedrosa-Menabrito \& Regenstein (1988); Stammen et al. (1990); Church \& Parsons (1995); Fernández Álvarez (2000) e Sivertsvik et al. (2002) documentaram a habilidade das EAMs em aumentar o tempo de vida útil de vários produtos perecíveis como carnes, aves e peixes.

Pesquisadores têm estabelecido que o armazenamento de pescado sob atmosfera 
modificada aumenta o tempo de vida útil dos mesmos. Misturas variáveis de gases têm sido utilizadas para produzir a inibição microbiana em sistemas com EAM (Lindsay, 1981). Geralmente as EAMs com alto nível de $\mathrm{CO}_{2}$ melhoram a estabilidade do pescado in natura, resultando em um aumento do tempo de vida útil deste (Baker et al., 1990).

\subsubsection{A ação dos gases nos microrganismos}

Segundo Daniels et al. (1985) há muitas teorias relatando as maneiras de como o $\mathrm{CO}_{2}$ exerce sua influencia sobre as células bacterianas, dentre elas pode-se destacar: - alteração nas funções das membranas celulares, incluindo os efeitos sobre os nutrientes; - inibição direta de enzimas ou diminuição das reações enzimáticas; penetração nas membranas das bactérias conduzindo a mudanças do $\mathrm{pH}$ intracelular e mudanças diretas nas propriedades físico-químicas das proteínas.

$\mathrm{O} \mathrm{N}_{2}$ é um gás insípido, inerte e com baixa solubilidade em água e em Ipídeos. É usado para o deslocamento do $\mathrm{O}_{2}$ em embalagens, diminuindo o ranço oxidativo e inibindo o crescimento de microrganismos aeróbios. Por causa de sua baixa solubilidade, é usado como gás preenchedor, prevenindo assim, o colapso das embalagens que pode acontecer quando produtos acumulam $\mathrm{CO}_{2}$ (Farber, 1991).

$\mathrm{O}_{2} \mathrm{O}_{2}$ geralmente estimula o crescimento de bactérias aeróbias e pode inibir o crescimento de bactérias estritamente anaeróbias, embora haja uma variação muito ampla na sensibilidade de anaeróbios ao $\mathrm{O}_{2}$ (Farber, 1991). A presença de $\mathrm{O}_{2}$ pode causar problemas de ranço oxidativo em peixes com alto teor de lipídeos; por esta razão, geralmente é excluído o uso de atmosferas com $\mathrm{O}_{2}$ para estas espécies, a fim de minimizar esses efeitos.

Em todos os alimentos manufaturados são reconhecidos os problemas de abuso de temperatura, visto que os efeitos bactericida e bacteriostático do $\mathrm{CO}_{2}$ são dependentes da temperatura (Church, 1998; Wolfe, 1980).

$\mathrm{O}$ uso de matérias-primas de alta qualidade higiênico-sanitária constitui um fator muito importante, quando se objetiva assegurar o sucesso do uso de embalagens, com atmosfera modificada. Além da matéria-prima com boa qualidade inicial é necessário que se faça o abate em condições higiênicas, a seleção do material correto da 
embalagem, proporção adequada de gases e manutenção do controle da temperatura (Stammen et al., 1990). A falta de refrigeração, em qualquer período, durante a vida útil de um produto, poderá permitir o crescimento de microrganismos que foram inibidos pelo $\mathrm{CO}_{2}$, durante o período de armazenamento a temperaturas mais baixas. Anaeróbios facultativos e patógenos aeróbios, que são resistentes aos efeitos antimicrobianos do $\mathrm{CO}_{2}$, e incapazes de crescer a baixas temperaturas, podem também crescer quando ocorre a chamada temperatura de abuso.

A ação conservadora não depende apenas da concentração de $\mathrm{CO}_{2}$ na embalagem e da temperatura, mas também das características dos produtos marinhos e de seu tempo de exposição no meio ambiente (Villemure et al., 1986).

Daniels et al. (1985) testaram os efeitos da solubilidade do $\mathrm{CO}_{2}$ no tratamento de filés de bacalhau (Gadus morhua) com ácido carbônico pulverizado a frio. A dissolução do gás ocorrente na fase aquosa foi eliminada e os efeitos diretos do ácido observados. Esses resultados indicaram que o ácido carbônico pulverizado foi tão efetivo quanto a atmosfera controlada com $98 \%$ de $\mathrm{CO}_{2}$. A inibição microbiana em EAM foi devido à dissolução do $\mathrm{CO}_{2}$. As pesquisas indicaram que o íon carbonato promoveu uma dissociação, mudanças na permeabilidade da célula e nos processos metabólicos dos microrganismos (Statham, 1984).

\subsubsection{Ação dos gases na carne}

Em alimentos com alto teor de umidade e/ou gordura, como o pescado, carne bovina e aves, a absorção excessiva de $\mathrm{CO}_{2}$ pode conduzir ao fenômeno conhecido como "colapso da embalagem". O aumento do fenômeno dripping ou exsudação é também causado pela dissolução dos gases na superfície da carne, com redução do pH, e conseqüente redução da capacidade das proteínas de reter água. Como consequiência, as altas concentrações de $\mathrm{CO}_{2}$ podem provocar mudanças organolépticas, como por exemplo, alteração da textura da carne (Parry, 1993).

$\mathrm{O}$ pescado embalado em atmosferas contendo alto nível de $\mathrm{CO}_{2}(>60 \%)$ também pode sofrer dripping (Randell et al., 1995). $\mathrm{O} \mathrm{N}_{2}$ pode ser usado como preenchedor inerte em uma proporção menor do que a de $\mathrm{CO}_{2}$ e o $\mathrm{O}_{2}$ também pode ser acrescentado 
desde que o pescado não apresente alterações na coloração (Cann et al., 1983).

Misturas de gases com $40 \% \mathrm{CO}_{2}+30 \% \mathrm{~N}_{2}+30 \% \mathrm{O}_{2}$ estão sendo recomendadas para pescado com baixo teor de gordura e 40 a $60 \%$ de $\mathrm{CO}_{2}$ em equilíbrio com $\mathrm{N}_{2}$, para pescado com alto teor de gordura (GUIDELINES..., 1985).

Para garantir o máximo de benefícios em pescado in natura armazenado sob refrigeração, Shewan (1950) sugeriu níveis de 30 a $40 \%$ de $\mathrm{CO}_{2}$ e Tarr (1966) estabeleceu níveis, de pelo menos, 40 a 50\% de $\mathrm{CO}_{2}$ na embalagem.

A inclusão do $\mathrm{O}_{2}$ em embalagens com atmosferas modificadas para pescado é questionada por Davis (1995). O autor discute que há evidências de que a inclusão de $\mathrm{O}_{2}$ reduz a exsudação ocorrida nos peixes durante o armazenamento, sugerindo que o $\mathrm{O}_{2}$ pode ser utilizado em embalagens, desde que para peixes magros. Reddy et al. (1992) defendem que a inclusão de $\mathrm{O}_{2}$ combinado com $\mathrm{N}_{2}$ ou $\mathrm{CO}_{2}$ dará uma falsa idéia de prevenção dos riscos de botulismo em pescado embalado in natura podendo oferecer uma falsa sensação de segurança.

$\mathrm{Na}$ presença de $\mathrm{O}_{2}$ podem ocorrer alterações autoxidativas no pescado induzindo a formação de aldeídos de baixo peso molecular, cetonas, álcoois e ácidos carboxílicos. A mistura de gases empregada depende da porcentagem de lipídeos do pescado que varia de 1 a $20 \%$, conforme a espécie. O pescado com alta porcentagem de gordura, como a cavala (Scomber japonicus) e o arenque (Clupea harengus), deve ser embalado em um meio livre de $\mathrm{O}_{2}$, para prevenir problemas de rancificação (Banks et al., 1980).

Segundo Holland (1980) alguns gases se dissolvem na carne, de acordo com sua solubilidade, proporção e temperatura de estocagem. As reações do tecido, no estado post mortem continuam, de modo que o $\mathrm{O}_{2}$ é consumido e o $\mathrm{CO}_{2}$ produzido. Além disso, o material de embalagem pode permitir alguma troca gasosa com a atmosfera externa. Portanto, a composição do espaço livre é resultado do equilíbrio de trocas gasosas que ocorrem, envolvendo a carne e a embalagem. Essa composição gasosa influencia na cor e determina o tipo e a velocidade do crescimento microbiano durante o período de armazenamento.

Daniels et al. (1986) investigaram os efeitos do ácido carbônico sobre o bacalhau (Gadus morhua) embalado com filme semipermeável e armazenado a $1^{\circ} \mathrm{C}$. O ácido 
carbônico foi capaz de aumentar a vida útil de 7 para 21 dias. Porém, o nível de qualidade foi julgado ruim, sensorialmente.

Wolfe (1980) concluiu que há um aumento da solubilidade do $\mathrm{CO}_{2}$ a baixas temperaturas em carne bovina, frango e pescado, e que o mesmo penetra através das células microbianas. A absorção do $\mathrm{CO}_{2}$ através das membranas celulares resulta em uma mudança intracelular do pH que afeta a ação normal enzimática.

Os efeitos da temperatura sobre a solubilidade do $\mathrm{CO}_{2}$ e inibição dos microrganismos em pescado foram avaliados por Ogrydziak \& Brown (1982). Sem levar em consideração o mecanismo sinergístico entre a temperatura e a solubilidade, as evidências demonstraram que o aumento da temperatura diminuiu a solubilidade do $\mathrm{CO}_{2}$ e aumentou o crescimento microbiano, proporcionalmente maior em EAM do que sob ar atmosférico.

\subsubsection{Proporção dos gases e a relação com tempo e temperatura}

Pesquisas realizadas por Coyne (1993a) sobre o efeito do $\mathrm{CO}_{2}$ em bacalhau (Gadus morhua) armazenado a $0^{\circ} \mathrm{C}$ e embalado sob atmosfera modificada $\left(100 \% \mathrm{CO}_{2}\right)$ mostraram que ocorreu aumento na vida útil de 50 a 100\% em relação ao controle.

Coyne (1933b) comparou a qualidade do bacalhau (Gadus morhua) armazenado a 0 e $10^{\circ} \mathrm{C}$, sob ar atmosférico e em várias concentrações de $\mathrm{CO}_{2}$. O bacalhau armazenado em $\mathrm{CO}_{2}$ apresentou aparência e aroma de produto fresco. $\mathrm{O}$ autor observou que as concentrações de $\mathrm{CO}_{2}$ de 40 a $60 \%$ são muito efetivas na preservação do pescado fresco, mantendo-o em ótimas condições.

Estudos conduzidos na Torry Research Station em Aberdeen, na Escócia, visando avaliar a qualidade dos filés de bacalhau (Gadus morhua), constataram aumento na vida útil de 3 a 4 dias, em atmosfera consistindo de $40 \% \mathrm{CO}_{2}+30 \% \mathrm{~N}_{2}+30 \% \mathrm{O}_{2}$, quando comparada com embalagens a vácuo (Cann, 1983).

Woyewoda et al. (1984) observaram que o crescimento bacteriano e a deterioração organoléptica em filés de bacalhau (Gadus morhua) refrigerados a $1^{\circ} \mathrm{C}$, diminuíram ligeiramente, em atmosfera com $60 \%$ de $\mathrm{CO}_{2}$. As pequenas diferenças existentes entre amostras mantidas em EAM e as mantidas sob ar atmosférico 
acentuaram-se com o tempo de armazenamento, evidenciando a qualidade das EAMs.

De acordo com Villemure et al. (1986) o bacalhau (Gadus morhua) eviscerado e filetado, estocado a granel, a $0 \pm 1^{\circ} \mathrm{C}$, em atmosfera composta de $25 \% \mathrm{CO}_{2}+75 \% \mathrm{~N}_{2}$, apresentou qualidade organoléptica aceitável até os 20 dias, e teve vida útil maior que o bacalhau armazenado sob ar atmosférico. $\mathrm{O}$ pH da superfície do pescado, apresentou-se na faixa de 6,6 e 7,5, para os embalados em EAM e sob ar atmosférico, respectivamente.

Einarsson \& Valdimarsson (1991) armazenaram o bacalhau (Gadus morhua) inteiro a granel, sob $100 \%$ de $\mathrm{CO}_{2}$ a $0^{\circ} \mathrm{C}$. Os autores observaram um aumento da vida útil de 4 dias, quando comparado com o bacalhau armazenado sob ar atmosférico.

Brown et al. (1980) submeteram filés de "rockfish" (Sebastes miniatus) e salmão do Pacífico fatiado (Oncorhynchus kisutch) ao embalamento sob atmosferas com 20 e $40 \%$ de $\mathrm{CO}_{2}$ e armazenamento a $4,5^{\circ} \mathrm{C}$. Os autores estabeleceram que a atmosfera com $40 \%$ de $\mathrm{CO}_{2}$, foi a mais benéfica, para ambas as espécies.

Barnett et al. (1982) compararam o salmão do Pacífico (Oncorhynchus kisutch) descabeçado, eviscerado e armazenado em contêineres sob atmosfera com $90 \%$ de $\mathrm{CO}_{2}$ a $0^{\circ} \mathrm{C}$, com o salmão armazenado sob ar atmosférico. Os autores observaram que o salmão armazenado em EAM manteve-se em condições aceitáveis por mais de 21 dias, enquanto que a vida útil do salmão armazenado sob ar atmosférico foi de 12 dias.

Haard \& Lee (1982) armazenaram postas de salmão do Atlântico (Salmo salar) a $3^{\circ} \mathrm{C}$, sob ar atmosférico, EAM e EAC (embalagem sob atmosfera controlada). Os resultados indicaram que as amostras mantidas sob ar atmosférico desenvolveram odor e apresentaram aparência desagradável depois de 10 dias, enquanto que aquelas armazenadas em EAM apresentavam uma mistura de aromas, levemente carbonatados, e aparência desagradável. As amostras armazenadas em EAC mantiveram as características de aroma e textura de peixe fresco. $\mathrm{O}$ desenvolvimento de trimetilemina não ocorreu em nenhuma das amostras mantidas sob ar atmosférico até $6^{\underline{0}}$ dia de armazenamento; as amostras armazenadas em EAM e em EAC apresentaram trimetilamina somente depois de 14 dias e 21 dias, respectivamente.

A vida útil de postas de salmão do Atlântico (Salmo salar) embaladas com $\mathrm{CO}_{2} \mathrm{e}$ ar atmosférico, armazenadas sob refrigeração a $2 \pm 1{ }^{\circ} \mathrm{C}$, durante 3 semanas, foi estudada 
por Pastoriza et al. (1996a). Os autores observaram que as postas de salmão armazenadas sob $\mathrm{CO}_{2}$ apresentaram uma vida útil duas vezes maior que aquelas armazenadas sob ar atmosférico. As postas de salmão foram armazenadas sob $\mathrm{CO}_{2}$, por aproximadamente, 18 dias sem perda de qualidade.

A qualidade do salmão do Atlântico (Salmo salar) filetado e embalado a vácuo; em EAM com $40 \% \mathrm{CO}_{2}+60 \% \mathrm{~N}_{2}$ e $60 \% \mathrm{CO}_{2}+40 \% \mathrm{~N}_{2}$; e sob ar atmosférico e mantidos a $2^{\circ} \mathrm{C}$ durante o transporte a granel, foi avaliada por Randell et al. (1999). Os filés em EAM apresentaram menor crescimento microbiano, e qualidade sensorial superior.

Sivertsvik et al. (1999) avaliaram a qualidade do salmão do Atlântico (Salmo salar) inteiro e eviscerado e embalado em bolsas plásticas com 50 e $100 \%$ de $\mathrm{CO}_{2}$; $60 \% \mathrm{CO}_{2}+40 \% \mathrm{O}_{2}$ e em embalagens tradicionais (poliestireno) durante o transporte sob refrigeração $\left(<1^{\circ} \mathrm{C}\right)$, após 13 dias de armazenamento refrigerado. Os autores observaram que o crescimento microbiano foi mais elevado no salmão embalado tradicionalmente $\mathrm{e}$ a qualidade sensorial foi superior no salmão embalado em EAM.

Lannelongue et al. (1982) e Gupta et al. (1991) relataram que atmosferas com 60 a $100 \%$ de $\mathrm{CO}_{2}$ foram efetivas em retardar o crescimento microbiano em camarões (Penaeus aztecus) e em tainha (Mugil keelarti) quando armazenados sob refrigeração a $4^{\circ} \mathrm{C}$ e $6-7^{\circ} \mathrm{C}$, respectivamente, além de apresentarem baixos níveis de bases nitrogenadas voláteis totais (BNVT) e decréscimo do $\mathrm{pH}$ durante o período de armazenamento.

Passy et al. (1983) avaliaram a vida útil do camarão de água doce (Macrobrachium rosenbergii) embalado em EAM $\left(100 \% \mathrm{CO}_{2}\right)$ e mantido a $4^{\circ} \mathrm{C}$. Os autores observaram que a vida útil do camarão foi aumentada de 2 a 3 dias, armazenado sob gelo, para 8 a 9 dias quando foi utilizada a EAM.

$\mathrm{O}$ armazenamento de camarão (Pandalus platyceros) sob atmosfera controlada com $100 \%$ de $\mathrm{CO}_{2}$ foi pesquisado Matches \& Layrisse (1985). Os autores observaram descolorações moderadas, e ausência de odores indesejáveis, ao passo que a amostra controle, que se constituiu de peixes expostos ao ar atmosférico, apresentou-se inaceitável. A elevada concentração de $\mathrm{CO}_{2}$ colaborou para evitar o aparecimento de manchas negras de natureza enzimática.

$\mathrm{O}$ efeito da EAM com $100 \%$ de $\mathrm{N}_{2}$ em camarões (Pandalus borealis) 
armazenados a $-17^{\circ} \mathrm{C}$, foi estudado por Bak et al. (1999). Os autores observaram que os camarões alcançaram vida útil de 9 meses, resultando em melhor coloração, menor oxidação e apresentando uma carne de textura mais firme em relação ao armazenamento sob ar atmosférico.

Pastoriza et al. (1996b) estudaram a vida útil de postas de merluza (Merluccius merluccius $)$ armazenadas sob refrigeração $\left(2 \pm 1{ }^{\circ} \mathrm{C}\right)$ em diferentes atmosferas $\left(40 \% \mathrm{CO}_{2}+50 \% \mathrm{~N}_{2}+10 \% \mathrm{O}_{2} ; \quad 60 \% \mathrm{CO}_{2}+30 \% \mathrm{~N}_{2}+10 \% \mathrm{O}_{2} ; \quad 40 \% \mathrm{CO}_{2}+30 \% \mathrm{~N}_{2}+30 \% \mathrm{O}_{2}\right.$; $60 \% \mathrm{CO}_{2}+10 \% \mathrm{~N}_{2}+30 \% \mathrm{O}_{2}$ ), tendo o ar atmosférico como controle. Os autores observaram que as postas de merluza podem ser armazenadas em embalagens sob atmosfera modificada e refrigeradas até 21 dias, sem perda de qualidade.

A vida útil de postas de merluza (Merluccius capensis) embaladas a vácuo (400 MPa) e mantidas sob refrigeração (2 a 3 ${ }^{\circ} \mathrm{C}$ ), foi avaliada por Hurtado et al. (2000). A merluza foi aceita sensorialmente até 43 dias de armazenamento. Foram encontrados baixos níveis de trimetilamina, e leve aumento do drip, depois de 15 dias de armazenamento.

Ordóñez et al. (2000) armazenaram sob refrigeração a $2 \pm 1{ }^{\circ} \mathrm{C}$, postas de merluza (Merluccius merluccius) sob atmosferas contendo 20 e $40 \%$ de $\mathrm{CO}_{2}$ e sob ar atmosférico. Os autores observaram que a vida útil aumentou para 4 e 11 dias nos produtos sob 20 e $40 \%$ de $\mathrm{CO}_{2}$, respectivamente, sendo a última a mais efetiva.

A merluza inteira e eviscerada foi armazenada em caixas com gelo $\left(0 \pm 1^{\circ} \mathrm{C}\right)$ sob atmosfera controlada (AC) com diferentes misturas $\left(60 \% \mathrm{CO}_{2}+15 \% \mathrm{O}_{2}+25 \% \mathrm{~N}_{2}\right.$; $40 \% \mathrm{CO}_{2}+40 \% \mathrm{O}_{2}+20 \% \mathrm{~N}_{2} ; 60 \% \mathrm{CO}_{2}+40 \% \mathrm{O}_{2}$ e $40 \% \mathrm{CO}_{2}+60 \% \mathrm{O}_{2}$ ), durante 33 dias. RuizCapillas \& Moral (2001) observaram por meio de análises físico-químicas e sensoriais, que a $\mathrm{AC}$ com $60 \% \mathrm{CO}_{2}+40 \% \mathrm{O}_{2}$, foi a mais efetiva em relação à demais misturas, apresentando uma melhor aceitação sensorial.

As mudanças químicas, físicas e microbiológicas do "catfish" Europeu (Silurus glanis) cultivado foram avaliadas durante o período de armazenamento por Manthey et al. (1988). O limite de aceitabilidade foi estabelecido para 20 dias. Aos 27 dias de armazenamento os filés apresentaram contagem total de bactérias anaeróbias de $10^{8} \mathrm{UFC} / \mathrm{cm}^{2}$ sob a superfície da pele e $10^{5} \mathrm{UFC} / \mathrm{g}$ de músculo. Os níveis de amônia 
aumentaram de 11,5 para 18,7 mg/100g de músculo, os valores de TBA foram de 0,73 a $1,98 \mathrm{mg}$ de MA $/ \mathrm{kg}$, depois de 27 dias. Os teores de trimetilamina foram muitos baixos, e a dimetilamina não foi detectada.

A contagem bacteriana e o $\mathrm{pH}$ superficial de filés de "catfish" (Ictalurus punctatus) embalados em atmosfera com $90 \% \mathrm{CO}_{2}+7,5 \% \mathrm{~N}_{2}+2,5 \% \mathrm{O}_{2}$ e sob ar atmosférico, armazenados a 0 e $10^{\circ} \mathrm{C}$ foram avaliados por Silva et al. (1993). Os autores observaram que $\mathrm{o} \mathrm{pH}$ não foi alterado pela temperatura, mas pelo tempo de armazenamento. Não ocorreram mudanças no $\mathrm{pH}$ no tratamento sob ar atmosférico, mas em EAM, ocorreu decréscimo de $\mathrm{pH}$ até o $12^{\underline{0}}$ dia de armazenamento. Outro efeito benéfico da EAM foi a baixa contagem bacteriana.

Hansen \& Jorgensen (1965) avaliaram a vida útil da truta (Salmo irideus) embalada individualmente a vácuo, em embalagens de poliamida e polietileno e armazenada sob gelo. Os autores observaram que a truta embalada em filme de polietileno apresentou uma alta oxidação da gordura, no final da segunda semana de armazenamento, enquanto que a embalada em poliamida não apresentou oxidação depois de três semanas. A contagem de microrganismos aeróbios foi mais alta na truta embalada em filme de polietileno.

Barnett et al. (1987) submeteram a truta (Salmo gairdneri) ao armazenamento sob atmosfera com $80 \% \mathrm{CO}_{2}+20 \% \mathrm{~N}_{2}$. Os autores observaram que a truta armazenada em EAM, a $1,7^{\circ} \mathrm{C}$, manteve-se com boa qualidade até os 14 dias, sendo considerada aceitável até os 25 dias de armazenamento, enquanto que a truta armazenada sob ar atmosférico apresentou-se deteriorada aos 12 dias de armazenamento.

Randell et al. (1997) avaliaram a qualidade da truta (Salmo gairdneri) e do arenque (Clupea harengus) em embalagens com filme de poliestireno, a vácuo e em EAM $\left(35 \% \mathrm{CO}_{2}+32,5 \% \mathrm{O}_{2}+32,5 \% \mathrm{~N}_{2} ; 35 \% \mathrm{CO}_{2}+65 \% \mathrm{O}_{2} ; 40 \% \mathrm{CO}_{2}+60 \% \mathrm{~N}_{2}\right)$ armazenados a $2^{\circ} \mathrm{C}$. Os autores observaram que as bactérias mesófilas cresceram mais em filés embalados em filme de poliestireno, e o número de coliformes foi maior em filés embalados a vácuo do que em EAM. Os filés armazenados a vácuo alteraram-se mais rapidamente que em EAM. A qualidade sensorial da truta e do arenque nos três tipos de embalagens foi semelhante. 
A atmosfera modificada com $80 \%$ de $\mathrm{CO}_{2}$ foi efetiva em aumentar a vida útil dos filés de "rockfish" (Sebastes spp) armazenados a $1,7 \pm 1^{\circ} \mathrm{C}$. Parkin et al. (1981) observaram baixos níveis de trimetilamina e decréscimo do $\mathrm{pH}$, provavelmente devido à absorção do $\mathrm{CO}_{2}$ pelos filés, além destes se apresentarem sensorialmente aceitáveis até o décimo terceiro dia de armazenamento.

A qualidade da lagosta cozida (Pacifastacus leniusculus) embalada em EAM com $80 \%$ de $\mathrm{CO}_{2}$ e $20 \%$ de ar atmosférico e armazenada a $4^{\circ} \mathrm{C}$, foi avaliada por Wang \& Brown (1983). Os autores observaram que depois de 28 dias de armazenamento, as concentrações de amônia, trimetilamina e a contagem de mesófilos foram mais baixas na lagosta armazenada em EAM do que sob ar atmosférico. Os provadores não encontraram diferenças significativas entre os odores, das amostras armazenadas em EAM e da lagosta fresca, até os 21 dias de armazenamento.

Huang et al. (1993) embalaram a pescada (Cynoscion regalis) em vários tipos de embalagens e a armazenaram sob gelo, durante 3 semanas. Os resultados mostraram que a embalagem a vácuo tipo skin evitou a hidrólise lipídica do pescado e a rancidez, quando comparada a embalagem tradicional, tipo overwrapping. A aceitabilidade microbiológica foi limitada para 14 dias e 17 dias, respectivamente, para a embalagem tipo overwrapping e embalagem a vácuo tipo skin.

Dhananjaya \& Stroud (1994) armazenaram o "haddock" (Melanogrammus aeglefinus,) e o arenque (Clupea harengus) inteiros e em filés, em diferentes atmosferas $\left(40 \% \mathrm{CO}_{2}+30 \% \mathrm{O}_{2}+30 \% \mathrm{~N}_{2} ; 60 \% \mathrm{CO}_{2}+20 \% \mathrm{O}_{2}+20 \% \mathrm{~N}_{2} ; 40 \% \mathrm{CO}_{2}+60 \% \mathrm{~N}_{2}\right)$ a 0,5 e $10^{\circ} \mathrm{C}$. Os resultados indicaram que a atmosfera com $60 \% \mathrm{CO}_{2}+20 \% \mathrm{O}_{2}+20 \% \mathrm{~N}_{2}$ foi a mais efetiva na manutenção dos componentes químicos e na qualidade sensorial, para o "haddock" e o arenque armazenados inteiros, a temperatura de $0^{\circ} \mathrm{C}$, prolongando a vida útil em 5 dias.

$\mathrm{O}$ efeito de atmosferas modificadas $\left(75 \% \mathrm{CO}_{2}+25 \% \mathrm{~N}_{2} ; \quad 50 \% \mathrm{CO}_{2}+50 \% \mathrm{~N}_{2}\right.$; $25 \% \mathrm{CO}_{2}+75 \% \mathrm{~N}_{2}$ ) sobre a vida útil de filés de tilápia (Tilapia $\mathrm{spp}$ ), embalados em filmes com alta barreira e armazenadas a $4^{\circ} \mathrm{C}$, foi avaliado por Reddy et al. (1994; 1995). Os autores observaram que os filés de tilápia, embalados com $75 \% \mathrm{CO}_{2}+25 \% \mathrm{~N}_{2}$ tiveram vida útil de 25 dias, apresentando características sensoriais aceitáveis. 
A qualidade sensorial, física, bioquímica e microbiana de filés de cavala (Scomber scombrus), armazenados a $-2^{\circ} \mathrm{C}$, em embalagens sob atmosfera modificada $\left(100 \% \mathrm{CO}_{2}\right)$ foram avaliadas por Hong et al. (1996). O armazenamento em EAM aumentou a vida útil para 21 dias, com um ligeiro aumento de bases nitrogenadas voláteis totais (BNVT) e trimetilamina (TMA). Também foi detectado número $<10$ $\mathrm{UFC/g}$ para coliformes, leveduras e bolores.

López-Gálvez et al. (1995; 1998) avaliaram através de parâmetros físicoquímicos e microbiológicos, postas de atum (Thunnus alalunga) e filés de solha (Solea solea), armazenados a $2^{\circ} \mathrm{C}$ sob diferentes atmosferas $\left(20 \% \mathrm{CO}_{2}+80 \%\right.$ ar atmosférico; $40 \% \mathrm{CO}_{2}+60 \%$ ar atmosférico e $40 \% \mathrm{CO}_{2}+60 \% \mathrm{O}_{2}$ ). Resultados sensoriais mostraram que a vida útil das postas de atum aumentou de 4 para 8 dias com 20 e $40 \%$ de $\mathrm{CO}_{2}$, respectivamente. A atmosfera com $40 \% \mathrm{CO}_{2}+60 \%$ ar atmosférico foi a mais efetiva, para as postas de atum; para os filés de solha, a atmosfera com $40 \% \mathrm{CO}_{2}+60 \% \mathrm{O}_{2}$, permitiu vida útil de uma semana.

Ozogul et al. (2000) compararam a qualidade do arenque (Clupea harengus) armazenado a granel sob gelo, submetido ao embalamento a vácuo e em EAM, mantido sob refrigeração a $2 \pm 2{ }^{\circ} \mathrm{C}$. Os autores observaram que a vida útil do arenque sob EAM foi prolongada em 10 dias e em 8 dias para a embalagem a vácuo, quando comparada com o arenque armazenado sob gelo.

\subsection{Efeito da atmosfera modificada sobre os microrganismos}

\subsubsection{Bactérias produtoras de histamina}

Algumas bactérias produzem histidina descarboxilase, uma enzima necessária para a produção de histamina a partir de L-histidina (Taylor, 1988). A intoxicação por histamina ocorre devido à ingestão de peixe deteriorado, especialmente atum, cavala, bonito, mahi-mahi, anchova, sardinha, arenque e solha. Esses peixes têm altos níveis do precursor e podem ser contaminados com a bactéria entérica (Stammen et al., 1990).

Watts \& Brown (1982) investigaram a formação de histamina em cavala do Pacífico (Scomber japonicus), armazenada a temperatura ambiente $\left(20^{\circ} \mathrm{C}\right) \mathrm{com} 80 \%$ de 
$\mathrm{CO}_{2}$. Os resultados indicaram que a atmosfera com $\mathrm{CO}_{2}$ não estimulou a formação de histamina; os níveis de histamina permaneceram baixos, tanto em atmosfera com $\mathrm{CO}_{2}$ quanto sob ar atmosférico. Cann et al. (1983) relataram situação semelhante em arenque (Clupea harengus) mantido em EAM. As baixas temperaturas e a sanitização efetiva podem controlar a formação bacteriana da histamina (Taylor, 1988).

Alguns Lactobacillus podem descarboxilar a histidina, e fermentar o pescado, que passa a ser fonte de intoxicação por histamina (Taylor, 1988).

Molin et al. (1983) armazenaram filés de arenque (Clupea harengus) sob ar atmosférico, $\mathrm{N}_{2}$ e $\mathrm{CO}_{2}$ a temperatura de $2^{\circ} \mathrm{C}$. Os autores isolaram somente Lactobacillus spp nos filés armazenados sob $\mathrm{CO}_{2}$, depois de 28 dias. Enquanto que nos filés armazenados sob $\mathrm{N}_{2}$ foram encontrados enterobacterias, Vibrio e Lactobacillus.

Wei et al. (1990) embalaram a vácuo e sob ar atmosférico amostras de atum (Thunnus albacares) inoculadas com Klebsiella oxytoca, Morganella morganii e Hafnia alvei. Os autores observaram em todas as amostras armazenadas a $10^{\circ} \mathrm{C}$, um significativo crescimento bacteriano e alto nível de histamina (> $200 \mathrm{mg} / 100 \mathrm{~g}$ ) após 15 dias de armazenamento. A embalagem a vácuo não apresentou qualquer efeito benéfico no controle do crescimento bacteriano e na produção de histamina, tanto a $10^{\circ} \mathrm{C}$ quanto à $2^{\circ} \mathrm{C}$.

\subsubsection{Pseudomonas, Lactobacillus, Alteromonas, Micrococcus, Moraxella e Achromobacter}

Em EAMs, a inibição de Gram-negativos, na forma de bastonete, como Pseudomonas, coincide com o crescimento de Gram-positivos, organismos produtores de ácido lático, como os Lactobacillus; o $\mathrm{CO}_{2}$ em concentração suficiente pode inibir o crescimento destes organismos (Hintlian \& Hotchkiss, 1987).

Lannelongue \& Finne (1986) isolaram Micrococcus varians, Pseudomonas florescens, Vibrio e Moraxella em "black drum" (Pogonias cromis), e os incubaram em meio sólido, mantidos a temperatura variando de 4 a $25^{\circ} \mathrm{C}$, sob ar atmosférico e em atmosferas com 25 e $100 \%$ de $\mathrm{CO}_{2}$. Com $25 \%$ de $\mathrm{CO}_{2}$ e $4^{\circ} \mathrm{C}$, todos os microrganismos 
cresceram, o Vibrio sp foi o mais sensível ao $\mathrm{CO}_{2}$ e o Micrococcus variens, o mais resistente.

King \& Nagel (1967) avaliaram vários fatores de crescimento da cultura pura de Pseudomonas aeruginosa, e estabeleceram uma relação linear positiva entre o tempo de geração e o nível de $\mathrm{CO}_{2}$. Essa relação também foi confirmada por Blickstad et al. (1981) que concluíram que o efeito bacteriostático e a conservação aumentaram com o aumento da concentração de $\mathrm{CO}_{2}$.

Banks et al. (1980) estudaram o efeito do $\mathrm{CO}_{2}$ em truta do Golfo (Cynoscion nebulosus) e na corvina (Micropogon undulatus) armazenadas a $4^{\circ} \mathrm{C}$. Os autores observaram que o $\mathrm{CO}_{2}$ inibiu o crescimento de bactérias deteriorativas, como Pseudomonas, e estimulou o crescimento de Lactobacillus.

O efeito residual da EAM com $80 \%$ de $\mathrm{CO}_{2}$ foi avaliado por Wang \& Ogrydziak (1986), em filés de "rockfish" (Sebastes spp) armazenados a $4^{\circ} \mathrm{C}$ em EAM e transferidos para o ar atmosférico. Os resultados indicaram que o efeito residual não correu devido à retenção de $\mathrm{CO}_{2}$ na superfície dos filés, mas provavelmente devido à ecologia microbiana do sistema. No armazenamento em EAM predominaram Lactobacillus spp e Alteromonas spp, mas depois de 6 dias armazenados sob ar atmosférico ocorreu um decréscimo dessas bactérias e um crescimento de Pseudomonas spp.

Enfors \& Molin (1981) estabeleceram que o aumento da inibição de P. fragi em arenque (Clupea harengus) a baixas temperaturas ocorre devido ao aumento da solubilidade do $\mathrm{CO}_{2}$. Haines (1933) relatou que concentrações tão baixas quanto 10 a $20 \%$ de $\mathrm{CO}_{2}$ são suficientes para inibir o crescimento de Pseudomonas e Achromobacter.

\subsubsection{Photobacterium phosphoreum}

Segundo Dalgaard et al. $(1993 ; 1995 ; 1998)$ o Photobacterium phosphoreum é a bactéria de maior incidência nas embalagens a vácuo e em EAM, com misturas de $\mathrm{CO}_{2} \mathrm{e}$ $\mathrm{N}_{2}$, em filés de bacalhau (Gadus morhua) armazenados a $0^{\circ} \mathrm{C}$.

Debevere \& Boskou (1996) avaliaram o comportamento da microbiota do bacalhau (Gadus morhua) sob diferentes atmosferas $\left(60 \% \mathrm{CO}_{2}+10 \% \mathrm{O}_{2}+30 \% \mathrm{~N}_{2}\right.$; 
$60 \% \mathrm{CO}_{2}+20 \% \mathrm{O}_{2}+20 \% \mathrm{~N}_{2} ; 60 \% \mathrm{CO}_{2}+30 \% \mathrm{O}_{2}+10 \% \mathrm{~N}_{2} ; 60 \% \mathrm{CO}_{2}+40 \% \mathrm{O}_{2}$ ) e armazenado a $6{ }^{\circ} \mathrm{C}$. Os autores observaram que a EAM contendo $60 \% \mathrm{CO}_{2}+40 \% \mathrm{O}_{2}$ manteve um efeito inibitório na atividade de trimetilamina e no crescimento da microbiota, reduzindo as células de $P$. phosphoreum.

Dalgaard et al. (1997), na Dinamarca, estudaram o crescimento de $P$. phosphoreum em 20 experimentos com pescado in natura armazenados em EAM a $0^{\circ} \mathrm{C}$. Os autores observaram o crescimento de $P$. phosphoreum em altos níveis (> $10^{7} \mathrm{UFC} / \mathrm{g}$ ) em todas as espécies marinhas, mas não detectaram a presença do microrganismo em pescado de água doce.

Filés de bacalhau (Gadus morhua) mantidos sob ar atmosférico a $0^{\circ} \mathrm{C}$, durante 1 a 8 dias, antes de serem mantidos em EAM e congelados a -20 e $-30^{\circ} \mathrm{C}$, durante 6 semanas, foram avaliados por Boknaes et al. $(2000 ; 2001)$. Foi detectado a presença de $P$. phosphoreum em níveis de 2,3 e 5,8 log UFC/g, depois de 1 e 8 dias, respectivamente. $\mathrm{O}$ armazenamento a -20 e $-30^{\circ} \mathrm{C}$ reduziu a contagem de $P$. phosphoreum, para valores abaixo do limite de detecção. Somente os filés mantidos por 8 dias a $0^{\circ} \mathrm{C}$, e posteriormente a $-30^{\circ} \mathrm{C}$ apresentaram, após descongelamento, um crescimento significativo de $P$. phosphoreum e aumento nos níveis de trimetilamina.

\subsubsection{Shewanella, Vibrio, Brochothrix, Yersinia e Bacillus cereus}

Boskou \& Debevere (1998) estudaram in vitro a influencia de fatores intrínsecos e extrínsecos na ação deterioradora da Shewanella putrefaciens, isolada do bacalhau (Gadus morhua) em EAM com $60 \% \mathrm{CO}_{2}+30 \% \mathrm{O}_{2}+10 \% \mathrm{~N}_{2}$. Os autores observaram que o aumento dos níveis de $\mathrm{CO}_{2}(\geq 50 \%)$ inibiu o crescimento de $S$. putrefaciens, e conseqüientemente diminuiu a produção de trimetilamina.

Em outra pesquisa, foram isoladas 2 espécies de Shewanella spp em filés de bacalhau (Gadus morhua) embalados em atmosfera contendo $60 \% \mathrm{CO}_{2}+30 \% \mathrm{O}_{2}+10 \% \mathrm{~N}_{2}$. Boskou \& Debevere (1997) utilizaram um meio sólido com extrato do peixe, procederam ao embalamento e incubação a $7^{\circ} \mathrm{C}$ durante 7 dias. Os autores concluíram que para as altas concentrações de $\mathrm{CO}_{2}$ devem ser incluídas também concentrações significativas de $\mathrm{O}_{2}$, objetivando a redução da atividade de Shewanella spp e a produção 
de óxido de trimetilamina (OTM). Os autores sugerem a combinação de 60 a $70 \%$ de $\mathrm{CO}_{2}$ e 30 a $40 \%$ de $\mathrm{O}_{2}$ para prevenir a produção de trimetilamina pela Shewanella spp.

Em atmosferas com $50 \%$ de $\mathrm{CO}_{2}$, a $S$. putrefaciens tem sido relatada como dominante da flora de bacalhau (Gadus morhua) juntamente com Lactobacillus spp (Stenström, 1985).

Hackney \& Dicharry (1988) demonstraram que a presença de Vibrio spp em pescado marinho é sazonal (meses quentes), porque este gênero é sensível ao calor. Conseqüentemente, os surtos se devem à ingestão de moluscos in natura, ou a contaminação durante o preparo. Lee (1981) relatou que não houve crescimento do $V$. parahaemolyticus em pescado embalado em EAM, com $60 \%$ de $\mathrm{CO}_{2}$, e armazenado em temperatura e $\mathrm{pH}$ considerados ótimos.

Eklund \& Jarmund (1983) estudaram o crescimento de vários microrganismos em caldo triptona de soja, armazenados em embalagens a vácuo, $\mathrm{CO}_{2}, \mathrm{~N}_{2}$ e sob ar atmosférico, a temperaturas de 2,6 e $20^{\circ} \mathrm{C}$. Os autores observaram que somente a combinação do $\mathrm{CO}_{2}$, com a temperatura de $2^{\circ} \mathrm{C}$, promoveu a completa inibição de Brochothrix thermosphacta e Yersinia enterocolitica.

Muitos estudos indicam que o Bacillus cereus é muito sensível aos efeitos antimicrobianos do $\mathrm{CO}_{2}$. Enfors \& Molin (1978) e Molin (1983) estabeleceram que de 11 microrganismos testados, o $B$. cereus foi o mais sensível à inibição, em filés de arenque (Clupea harengus) armazenados sob $100 \%$ de $\mathrm{CO}_{2} . \mathrm{O}$ crescimento a $25^{\circ} \mathrm{C}$, foi inibido com 83 e $67 \%$ de $\mathrm{CO}_{2}$, no caso de microrganismos aeróbios e anaeróbios, respectivamente.

\subsubsection{Aeromonas, Listeria e Escherichia coli}

Davis \& Slade (1995) estudaram o crescimento e a sobrevivência de Aeromonas spp e Y. enterolitica em bacalhau (Gadus morhua) embalado em $60 \% \mathrm{CO}_{2}+40 \% \mathrm{~N}_{2}$ e $40 \% \mathrm{CO}_{2}+30 \% \mathrm{~N}_{2}+30 \% \mathrm{O}_{2}$ e em truta (Oncorhyncus mykiss) embalada em $60 \% \mathrm{CO}_{2}+40 \% \mathrm{~N}_{2}$ e $80 \% \mathrm{CO}_{2}+20 \% \mathrm{~N}_{2}$ armazenados a 0,5 e $12^{\circ} \mathrm{C}$. Os autores observaram que a redução no crescimento destes microrganismos foi maior na atmosfera com a concentração mais alta de $\mathrm{CO}_{2}$ e na temperatura de $0^{\circ} \mathrm{C}$. 
Lyver et al. (1998b) estudaram as alterações em nuggets preparados a partir de surimi e inoculados com $10^{3}$ esporos de L. monocytogenes. Todos os produtos foram embalados sob ar atmosférico, juntamente com absorvente de oxigênio e mantidos por 28 dias a temperatura de 4 a $12^{\circ} \mathrm{C}$. Os autores relataram que as contagens de Bacillus spp e de bactérias ácido láticas, em nuggets, aumentaram para $10^{2}$ e $10^{7} \mathrm{UFC} / \mathrm{g}$ respectivamente, entretanto, somente o Bacillus spp alcançou $10^{4} \mathrm{UFC} / \mathrm{g}$ no $28^{\circ}$ dia em nuggets submetidos à cocção. Quanto aos nuggets embalados com $100 \%$ de $\mathrm{CO}_{2}$, com ou sem absorvente, a contagem de L. monocytogenes aumentou para $10^{7} \mathrm{UFC} / \mathrm{g}$, depois de armazenado por 28 dias, em ambas as temperaturas.

O aumento da população de L. monocytogenes com o armazenamento foi observado por Harrison et al. (1991), em camarão (Pandalus platyceros) embalado a vácuo e em EAM mantidos até 21 dias, sob refrigeração a $0^{\circ} \mathrm{C}$.

Leung et al. (1992) estudaram o desenvolvimento de L. monocytogenes e Aeromonas hydrophila em filés de "catfish" (Ictalurus punctatus) em embalagem a vácuo, tipo skin e em embalagem tradicional, tipo overwrapping, armazenados durante 16 dias sob refrigeração a $4^{\circ} \mathrm{C}$. Os autores observaram que não houve aumento da população de L. monocytogenes, mas o crescimento da população de A. hydrophila foi mais rápido nos produtos sob embalagem tradicional, tipo overwrapping.

Mokhele et al. (1983) observaram o crescimento de microrganismos em "rockfish" (Sebastes spp) embalado em EAM com $80 \%$ de $\mathrm{CO}_{2}$ e armazenado a $4^{\circ} \mathrm{C}$. Os autores encontraram somente Lactobacillus sp e Aeromonas sp em EAM; no armazenamento sob ar atmosférico observaram uma grande diversidade de bactérias.

De acordo com Dorsa et al. (1993) a temperatura de $6^{\circ} \mathrm{C}$ inibiu o crescimento de L. monocytogenes, mas a de abuso $\left(12^{\circ} \mathrm{C}\right)$, por um curto período de tempo, induziu um rápido crescimento do microrganismo sobre a carne de lagosta (Procambarus claekii).

Church (1998) não observou a inibição de L. monocytogenes em bacalhau (Gadus morhua) embalado em EAM composta de $40 \% \mathrm{CO}_{2}+30 \% \mathrm{~N}_{2}+30 \% \mathrm{O}_{2}$ e $60 \% \mathrm{CO}_{2}+40 \% \mathrm{~N}_{2}$. 


\subsubsection{Clostridium botulinum}

Muitos pesquisadores têm se preocupado com o aumento do potencial de crescimento do Clostridium botulinum em EAMs. A preocupação é bem fundamentada pela importância patogênica deste microrganismo. O Clostridium spp é o agente causal de doenças gastrintestinais e o responsável pela produção de uma neurotoxina que causa paralisia facial (Hintlian \& Hotchkiss, 1986).

Filés de salmão do Pacífico (Oncorhynchus tshawytscha) inoculados por Stier et al. (1981) com C. botulinum tipos A, B e E e embalados sob ar atmosférico e em EAMs contendo $60 \% \mathrm{CO}_{2}+25 \% \mathrm{O}_{2}+15 \% \mathrm{~N}_{2}$, mantidos a $4,4^{\circ} \mathrm{C}$ e armazenados por 57 dias, não apresentaram toxina. Os autores concluíram que as EAMs não intensificaram o crescimento de $C$. botulinum a $4,4^{\circ} \mathrm{C}$ e que a deterioração precedeu ou coincidiu com a produção de toxina a $22,2^{\circ} \mathrm{C}$.

Post et al. (1985) estudaram a produção de toxina pelo C. botulinum tipo $\mathrm{E}$ em bacalhau (Gadus morhua), merluza (Merluccius bilinearis) e linguado (Limanda ferrugina), embalados em filme permeável sob ar atmosférico, a vácuo e em embalagens com $\mathrm{N}_{2}$ e $\mathrm{CO}_{2}$, mantidos a 8,12 e $26^{\circ} \mathrm{C}$. Os autores observaram que o linguado deteriorou-se rapidamente, e foi rejeitado sensorialmente antes da produção de toxina, nas amostras armazenadas a vácuo e em EAM, a 12 e $8^{\circ} \mathrm{C}$. Enquanto que no bacalhau e na merluza, a presença da toxina antecedeu ou ocorreu simultaneamente à rejeição sensorial.

Garcia et al. (1987) inocularam filés de salmão do Pacífico (Oncorhynchus tshawytscha) com esporos de 13 cepas não proteolíticas de $C$. botulinum tipo $\mathrm{B}, \mathrm{E}$ e $\mathrm{F}$ incubadas a $4,8,12$ e $30^{\circ} \mathrm{C}$, em EAM $\left(100 \% \mathrm{CO}_{2} ; 70 \% \mathrm{CO}_{2}+30 \%\right.$ ar atmosférico) e a vácuo. Os autores observaram que somente os filés armazenados a $4^{\circ} \mathrm{C}$ não apresentaram toxina até o $60^{\circ}$ dia de armazenamento.

A superfície de moluscos (mytilus sp) foi inoculada com uma mistura de esporos de C. botulinum dos tipos A, B, E e F, e embalados a vácuo a 4,10 e $27^{\circ} \mathrm{C}$. O desenvolvimento de toxina ocorreu somente a $27^{\circ} \mathrm{C}$, depois de 45 horas (Fletcher et al., 1988). 
Lerke \& Farber (1971) embalaram o camarão (Pandalus platyceros) e carne de caranguejo (Geryon quinquedens) sob vácuo, previamente inoculados com aproximadamente 300 esporos/g de C. botulinum, tipo E, e os armazenaram a 10 e $4,4^{\circ} \mathrm{C}$. Os autores observaram que os produtos já se apresentavam deteriorados aos $14 \mathrm{e}$ 27 dias, respectivamente, antes da produção de toxina.

Baker et al. (1990) inocularam esporos de C. botulinum, tipo E, em concentrações de $10^{-2}$ a $10^{4}$ esporos/amostra, em "rockfish" (Sebastes paucispinis), salmão do Pacífico (Oncorhynchus tshawytscha) e solha (Microstomus pacificus). Os produtos sob vácuo e EAM com $100 \%$ de $\mathrm{CO}_{2}$ foram armazenados entre 4 e $30^{\circ} \mathrm{C}$ durante 60 dias. Para todos os tratamantos aplicados os resultados demonstraram a habilidade de poucos esporos, crescerem individualmente, ou em conjunto a temperatura de 8 a $30^{\circ} \mathrm{C}$.

As alterações de cor e pH foram avaliados por Silva \& White (1994), em filés de "catfish" (Ictalurus punctatus) armazenados sob atmosferas com 25\% de $\mathrm{CO}_{2}, 80 \%$ de $\mathrm{CO}_{2}$ e em ar atmosférico a 2 e $8^{\circ} \mathrm{C}$, durante 4 semanas. Os autores observaram que o $\mathrm{pH}$ decresceu, no tratamento com $80 \%$ de $\mathrm{CO}_{2}$. O C. botulinum não foi encontrado em qualquer tipo de embalagem, temperatura e período de armazenamento. O melhor tratamento foi o que recebeu $80 \%$ de $\mathrm{CO}_{2}$ e armazenamento a $2^{\circ} \mathrm{C}$.

Reddy et al. (1997a) avaliaram o potencial de produção de toxina do $C$. botulinum tipo E em filés de "catfish" (Ictalurus punctatus) embalados em bolsa com filme de alta barreira e armazenados a 4 e $16^{\circ} \mathrm{C}$. Os autores observaram que o desenvolvimento de toxina coincidiu com a rejeição sensorial a $16^{\circ} \mathrm{C}$. A $4^{\circ} \mathrm{C}$, os filés apresentaram desenvolvimento de toxina depois de 37 dias da rejeição sensorial.

O potencial de produção de toxina do C. botulinum tipo E foi avaliado por Reddy et al. (1996; 1997b), em filés de tilápia (Tilapia spp) e de salmão do Atlântico (Salmo spp) cultivados e embalados em bolsa com filme de alta barreira sob $100 \%$ de ar atmosférico, em EAM com $75 \% \mathrm{CO}_{2}+25 \% \mathrm{~N}_{2}$ e a vácuo, armazenados a 4,8 e $16^{\circ} \mathrm{C}$. Os autores observaram que a vida útil dos filés embalados diminuiu com o aumento da temperatura de $4^{\circ} \mathrm{C}$ para $16^{\circ} \mathrm{C}$. A $16^{\circ} \mathrm{C}$, o desenvolvimento de toxina precedeu a rejeição sensorial para os filés embalados em EAM. Já a $8^{\circ} \mathrm{C}$, o desenvolvimento de toxina 
coincidiu com a rejeição sensorial em todas as atmosferas. A $4^{\circ} \mathrm{C}$, a rejeição sensorial precedeu o desenvolvimento de toxina.

Cai et al. (1997) inocularam o "catfish" (Ictalurus punctatus) com uma mistura de 4 cepas de $C$. botulinum tipo E, embalaram em filme permeável ao $\mathrm{O}_{2}$ e em EAM, com $80 \% \mathrm{CO}_{2}+20 \% \mathrm{~N}_{2}$, e armazenaram a $4^{\circ} \mathrm{C}$. A produção de toxina foi detectada após 9 e 18 dias, nas embalagens com filme permeável ao $\mathrm{O}_{2}$ e em EAM, respectivamente. Em todas as embalagens a deterioração precedeu a produção de toxina.

Lyver et al. (1998a) estudaram as alterações em nuggets preparados com surimi, cozidos e esterilizados, inoculados com $10^{4}$ esporos de C. botulinum tipo E. Todos os produtos foram embalados sob ar atmosférico, juntamente com absorvente de oxigênio e mantidos a 4,12 e $25^{\circ} \mathrm{C}$, durante 28 dias. Os autores não detectaram a presença de toxina em nenhum produto, devido à presença de Bacillus spp.

\subsection{Utilização de ácidos orgânicos na conservação de alimentos}

Algumas investigações têm sido feitas para a possibilidade de combinar EAMs com conservantes em pescado in natura, com a finalidade de oferecer produtos de melhor qualidade e maior vida útil.

Os ácidos acético e lático, produzidos microbiologicamente, são conhecidos pelos efeitos bactericida e bacteriostático, e são encontrados em alguns produtos fermentados como iogurte, chucrute, picles, salames e outros. O consenso de que esses ácidos têm baixa toxicidade ao organismo humano incentiva o seu uso como agente da redução da contaminação microbiológica em carnes (Adams \& Hall, 1988).

Devido à baixa solubilidade, ao sabor e àbaixa toxicidade ao organismo humano, os ácidos orgânicos de cadeia curta como o acético, benzóico, cítrico, propiônico, sórbico e lático, são os mais comumente usados em alimentos. O ácido acético e seus sais são bastante eficientes e largamente utilizados como acidulantes e conservadores de alimentos. Sua ação conservadora é atribuída à queda de $\mathrm{pH}$ provocada no meio, e sua atividade antimicrobiana inicia-se em concentrações superiores a $0,5 \%$. A presença de 1 a $2 \%$ de ácido não dissociado na carne, pescado e vegetais é geralmente suficiente para a inibição bacteriana, desde que boas condições de higiene sejam mantidas (Pardi et al., 
1994). Os ácidos orgânicos são classificados como conservadores ou como acidulantes pela legislação brasileira conforme o Decreto $\mathrm{n}^{\mathrm{0}} 55871$ de 23/06/1965; são definidos como substâncias que são adicionadas aos alimentos com vistas a impedir ou retardar a ação microbiana ou enzimática, protegendo o alimento contra a deterioração (BRASIL, 2001b).

De acordo com Luck (1981) sobre um substrato acidificado a pH 3,0, a atividade antimicrobiana do ácido acético é 10 a 100 vezes superior à de qualquer outro ácido. Atribui-se esta diferença ao fato de o ácido acético não dissociado penetrar mais intensamente na célula devido à sua lipossolubilidade. A atividade do ácido acético é duplicada na faixa de $\mathrm{pH}$ 5,0 e 6,0.

As moléculas não dissociadas do ácido acético podem penetrar na membrana celular, dissociar-se no citoplasma e eventualmente alterar o pH intracelular e o potencial eletroquímico da membrana (Kabara \& Eklund, 1991). A presença do ácido acético na fase logarítmica do crescimento bacteriano pode resultar na morte dos microrganismos (Smulders \& Woolthuis, 1985; Van Netten et al., 1984).

Debevere \& Voets (1972) estudaram as alterações ocorridas em filés de bacalhau (Gadus morhua) pré-embalados, no que se refere ao uso de diferentes concentrações de ácido cítrico e sorbato de potássio. A concentração de $0,4 \%$ de sorbato de potássio presente nos filés de bacalhau foi suficiente para inibir completamente a produção de trimetilamina. O sorbato de potássio, juntamente com a utilização de filme de baixa permeabilidade ao $\mathrm{O}_{2}$, apresentou os melhores resultados.

Misturas de conservantes, como EDTA (1\%), ácido propiônico (0,7 e 1\%) ácido ascórbico (1\%) e $\mathrm{CO}_{2}$ (90\%) foram utilizadas por Windsor \& Thoma (1974), em espadilha (Clupea sprattus) que foram armazenadas, a $11 \pm 1^{\circ} \mathrm{C}$, durante 30 dias. Os resultados indicaram que a mistura mais efetiva foi a constituída de ácido propiônico e $\mathrm{CO}_{2}$.

Mitsuda et al. (1980) relataram os efeitos dos ácidos fórmico, succínico, acético, málico, cítrico, propiônico e lático, em concentração de $1 \%$ na alteração da cor de postas de choco (Seriola aurevettata). Todos os ácidos foram muito efetivos, exceto o ácido fórmico que não preveniu a alteração da cor, durante o armazenamento; o ácido 
succínico foi especialmente mais favorável na retenção da cor. $\mathrm{O}$ efeito favorável foi observado na seguinte ordem: ácido succínico > málico > acético > cítrico > propiônico e lático. Em relação à firmeza, os ácidos fórmico, succínico, málico, lático, cítrico e propiônico promoveram o amolecimento indesejável das postas, durante o armazenamento; o ácido acético permitiu a manutenção da textura firme do músculo, semelhante ao controle.

A ação do ácido lático a $10 \%$, lactato de sódio a $2 \%$ e do lactato de sódio com cloreto de sódio a $2 \%$ em filés de tilápia do Nilo (Oreochromis niloticus) refrigerados de 4 a $10^{\circ} \mathrm{C}$, foi estudada por Lima et al. (1998). O ácido lático a $10 \%$ teve uma boa ação sobre a microbiota dos filés e ampliou a vida útil dos mesmos, para 8 dias.

Mujica (2000) avaliou a eficiência do tratamento dos filés de cação (Prionace glauca) com ácido acético, em relação à redução dos teores de uréia e aumento da vida útil, tanto no armazenamento sob refrigeração $\left(0^{\circ} \mathrm{C}\right)$ como em temperatura de abuso $\left(10^{\circ} \mathrm{C}\right) . \mathrm{O}$ tratamento dos filés de cação com ácido acético a $1 \%$ durante 3 horas a $5^{\circ} \mathrm{C}$, mostrou-se eficiente na redução dos teores de uréia e a vida útil foi de aproximadamente, 3 e 12 dias, para o armazenamento a 10 e $0^{\circ} \mathrm{C}$, respectivamente.

Boskou \& Debevere (2000) estudaram o efeito do ácido acético a 10\% sobre filés de bacalhau (Gadus morhua) embalados em EAM, com $50 \% \mathrm{CO}_{2}+45 \% \mathrm{O}_{2}+5 \% \mathrm{~N}_{2}$, e armazenados a $7^{\circ} \mathrm{C}$, durante 12 dias. Os autores observaram a redução de microrganismos aeróbios, bactérias produtoras de $\mathrm{H}_{2} \mathrm{~S}$ e enterobactérias, e consequientemente, a inibição de trimetilamina (TMA) e bases nitrogenadas voláteis totais (BNVT).

\subsection{Tratamento com sais em pré-embalamento}

Williams et al. (1995) submeteram filés de "catfish" (Ictalurus nebulosus) in natura a soluções 0,1 e $2 \%$ de lactato de sódio, ajustaram o pH para 5,5, embalaram os filés a vácuo e os armazenaram a $1,11 \pm 1{ }^{\circ} \mathrm{C}$. A vida útil dos filés tratados com $2 \%$ de lactato de sódio foi aumentada de 4 para 7 dias.

De acordo com Shaw et al. (1983), a adição de sorbato de potássio em pescado in natura inibiu o crescimento de microrganismos deterioradores como Pseudomonas 
fluorescens, Pseudomonas fragi e a produção de trimetilamina por Alteromonas putrefaciens. Os autores observaram também o efeito do sorbato de potássio na inibição de patógenos como Clostridium botulinum e Staphylococcus aureus.

Regenstein (1982) estabeleceu que um efetivo controle no crescimento microbiano em pescado marinho in natura, pode ser observado quando o sorbato de potássio é usado em combinação com armazenamento sob atmosfera modificada.

Sharp et al. (1986) examinaram a vida útil de filés de truta salmonada (Coreogonus clupeaformis) tratados com 2,5 e 5\% de sorbato de potássio e embalados em bolsa com baixa, intermediária e alta barreira, sob atmosfera modificada com $100 \%$ de $\mathrm{CO}_{2}$, e mantidas sob refrigeração abaixo de $3^{\circ} \mathrm{C}$. Os autores observaram que o tratamento com 5\% de sorbato de potássio aumentou a vida útil, ultrapassando 14 dias de armazenamento. Em relação à permeabilidade dos filmes, não houve diferença significativa.

$\mathrm{O}$ uso de atmosferas modificadas, com 50 a $100 \%$ de $\mathrm{CO}_{2}$, e embalagens a vácuo, incorporando o tratamento com sorbato de potássio, tem tido sucesso no aumento da vida útil do "morwong" (Nemadactylus macropterus) e moluscos (Pecten alba) (Bremner \& Statham, 1983; Statham, 1984; Statham et d., 1985). A combinação desses dois tratamentos leva ao efeito sinergístico. Quando usado conjuntamente com atmosfera contendo $60 \%$ de $\mathrm{CO}_{2}$, o sorbato de potássio vaporizado ou incorporado ao gelo, foi efetivo em aumentar a vida útil da merluza (Merluccius merluccius) e do salmão do Atlântico (Salmo spp), por 4 semanas, a $1^{\circ} \mathrm{C}$ (Fey \& Regenstein, 1982; Regenstein, 1982).

Gibson et al. (2000) avaliaram o crescimento de esporos de C. botulinum não proteolíticos dos tipos $\mathrm{B}$ e E, isolados a 5 e $10^{\circ} \mathrm{C}$, em sistemas que combinaram os efeitos do $\mathrm{NaCl}(0,5-4,5 \%)$, pH $(5,5-6,5)$ e atmosferas com $10 \% \mathrm{H}_{2}+90 \% \mathrm{~N}_{2}$; $5 \% \mathrm{CO}_{2}+10 \% \mathrm{H}_{2}+85 \% \mathrm{~N}_{2}$ e $100 \%$ de $\mathrm{CO}_{2}$. Os autores observaram que o crescimento ocorreu em baixa proporção, somente quando o C. botulinum foi exposto a $100 \%$ de $\mathrm{CO}_{2}$. Os resultados indicaram que o $\mathrm{CO}_{2}$ diminuiu o crescimento de $C$. botulinum à temperatura de refrigeração, e que a prevenção do crescimento depende da concentração de $\mathrm{NaCl}$ e do $\mathrm{pH}$. 
$\mathrm{O}$ uso de $100 \%$ de $\mathrm{CO}_{2}$ juntamente com aspersão de polifosfato, para prevenir dripping do pescado é uma prática viável. Há algumas evidências de que os polifosfatos têm um efeito inibitório na flora bacteriana, em alimentos à base de carne (Elliott et al., 1964). Porém o aumento da vida útil, quando ocorre, é da ordem de 1 a 2 dias (Spencer \& Smith, 1962). A contenção na produção de toxina, pelo C. botulinum, em carne bovina, suína e salsichas ocorre devido ao sinergísmo entre o pirofosfato de sódio, o sorbato de potássio e o nitrato de sódio (Wagner \& Busta, 1983).

Igham \& Potter (1988) prepararam minced e surimi de "pollock" (Pollachius viuns) com diferentes níveis de proteína, $\mathrm{NaCl}$ e carboidratos. As amostras foram inoculadas com Aeromonas hydrophila e Pseudomonas fragi, embaladas em EAM com $51 \% \mathrm{~N}_{2}+13 \% \mathrm{O}_{2}+36 \% \mathrm{CO}_{2}$ e armazenadas a 5 e $13^{\circ} \mathrm{C}$. Os resultados indicaram que $A$. hydrophila foi mais afetada do que a P. fragi, pelo teor de sal empregado na elaboração do minced e do surimi.

$\mathrm{O}$ efeito de uma mistura de gases $\left(50 \% \mathrm{CO}_{2}+45 \% \mathrm{~N}_{2}+5 \% \mathrm{O}_{2}\right)$ em combinação com a aspersão de cloreto de sódio sobre postas de merluza (Merluccius merluccius) foi estudado por Pastoriza et al. (1998). Os tratamentos com cloreto de sódio pulverizado apresentaram maior inibição sob os pontos de vista bioquímico e microbiológico, e menor alteração sensorial, além de reduzida exsudação. A vida útil das postas de merluza foi de 2 dias, quando armazenadas em EAM, e 8 dias quando submetidas ao tratamento, com solução de cloreto de sódio e embaladas em EAM.

$\mathrm{O}$ efeito inibitório do nisin sobre a produção de toxina pelo C. botulinum tipo $\mathrm{E}$ foi estudado por Taylor et al. (1990), em bacalhau (Gadus morhua), arenque (Clupea harengus) e cavala defumada (Scomber japonicus), embalados com $100 \%$ de $\mathrm{CO}_{2} \mathrm{e}$ armazenados a 10 e $26^{\circ} \mathrm{C}$. Os autores observaram que o nisin não colaborou para o aumento da vida útil dos produtos. A produção de toxina ocorreu em todas as espécies, em ambas as temperaturas, antes de serem julgadas inaceitáveis para o consumo.

Nilsson et al. (1997) avaliaram o efeito bacteriostático e bactericida de nisin (500-1000 UI/mL) em combinação com $100 \%$ de $\mathrm{CO}_{2}$ e $\mathrm{NaCl}(0,5-5,0 \%)$ sobre a sobrevivência de L monocytogenes, in vitro, em salmão (Salmo spp) defumado a frio, mantido a 5 e $10^{\circ} \mathrm{C}$. Os autores observaram que a adição de nisin ao $\mathrm{CO}_{2}$ resultou na 
redução da ordem de 1 a $2 \log$ da L. monocytogenes acompanhado por uma inibição da fase logarítmica de 8 e 20 dias, com 500 e 1000 UI/g de nisin, respectivamente. Os níveis de L. monocytogenes permaneceram abaixo de $10^{3} \mathrm{UFC} / g$ durante 27 dias de armazenamento em ambas as concentrações de nisin.

O salmão do Atlântico (Salmo salar) defumado a frio foi embalado a vácuo e sob atmosfera modificada com $60 \% \mathrm{CO}_{2}+40 \% \mathrm{~N}_{2}$ e armazenado a $5^{\circ} \mathrm{C}$. Foi utilizado para a inibição de bactérias produtoras de ácido lático e bactérias Gram-negativas o nisin em conjunto com $\mathrm{CO}_{2}$. Paludan-Müller et al. (1998) observaram a inibição do crescimento de bactérias Gram-negativas e um aumento da vida útil de 4 semanas, nas mesmas condições.

O efeito de vários antioxidantes comerciais, sobre a oxidação lipídica de filés de carpa (Cyprinus carpio) in natura e cozidos, armazenados em embalagens com e sem vácuo, a $5^{\circ} \mathrm{C}$, durante 16 dias foi avaliado por Khalil \& Mansour (1998). O antioxidante mais efetivo foi a antracina 350, na concentração de $200 \mathrm{mg} / \mathrm{kg}$. Os filés cozidos apresentaram valores de TBA nais elevados, tanto em embalagens com ou sem vácuo, em relação aos filés in natura. Na avaliação sensorial, os filés in natura embalados a vácuo mostraram-se aceitáveis até o final do período de armazenamento. 


\section{MATERIAL E MÉTODOS}

\subsection{Pescado}

Foram utilizados peixes provenientes de criatório do Estado de São Paulo, região de Jaú, da espécie tilápia do Nilo, Oreochromis niloticus. Os peixes foram capturados de tanques-rede e transportados em tanques com aeração para o Setor de Piscicultura do Departamento de Zootecnia da ESALQ - USP. Em seguida foram submetidos à depuração em tanque com água corrente, proveniente de poço artesiano, onde permaneceram por $78 \mathrm{~h}$, em média, sem alimentação. Após este período, os peixes foram colocados, ainda vivos, diretamente em caixas de isopor, em camadas intercaladas com gelo preparado com água potável, onde sofreram o choque térmico. Os peixes em situação de hipotermia foram transportados ao Setor de Processamento de Alimentos do Departamento de Agroindústria, Alimentos e Nutrição da ESALQ - USP e imediatamente lavados em água corrente clorada, proveniente da rede pública de abastecimento. 

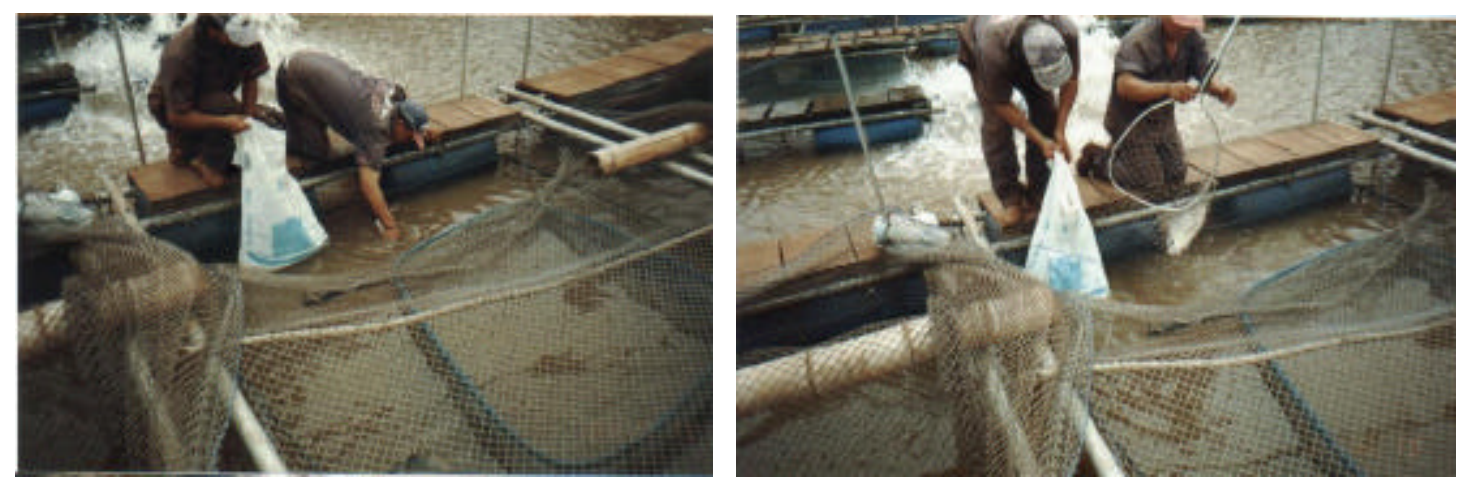

Figura 1 - Captura das tilápias em tanques-rede.
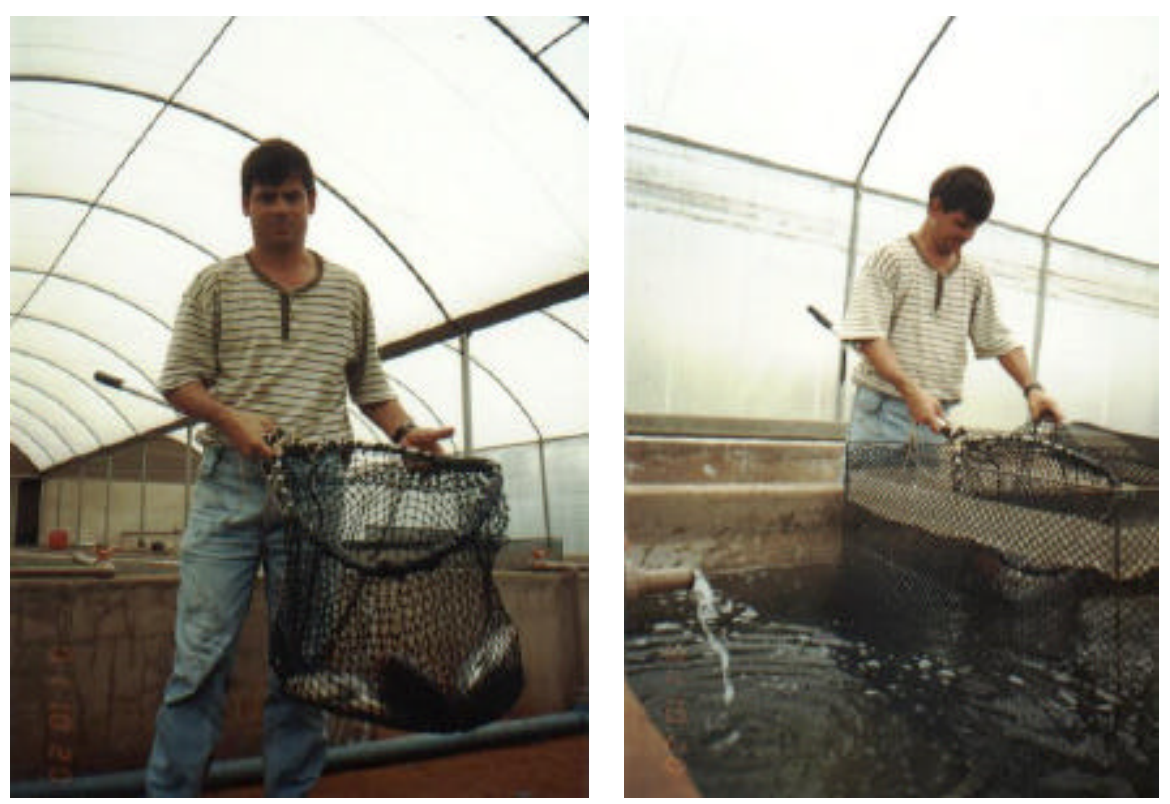

Figura 2 - Transferência das tilápias para a depuração em tanque com água corrente. 


\subsection{Metodologia de obtenção e análise dos produtos de pescado minimamente processado}

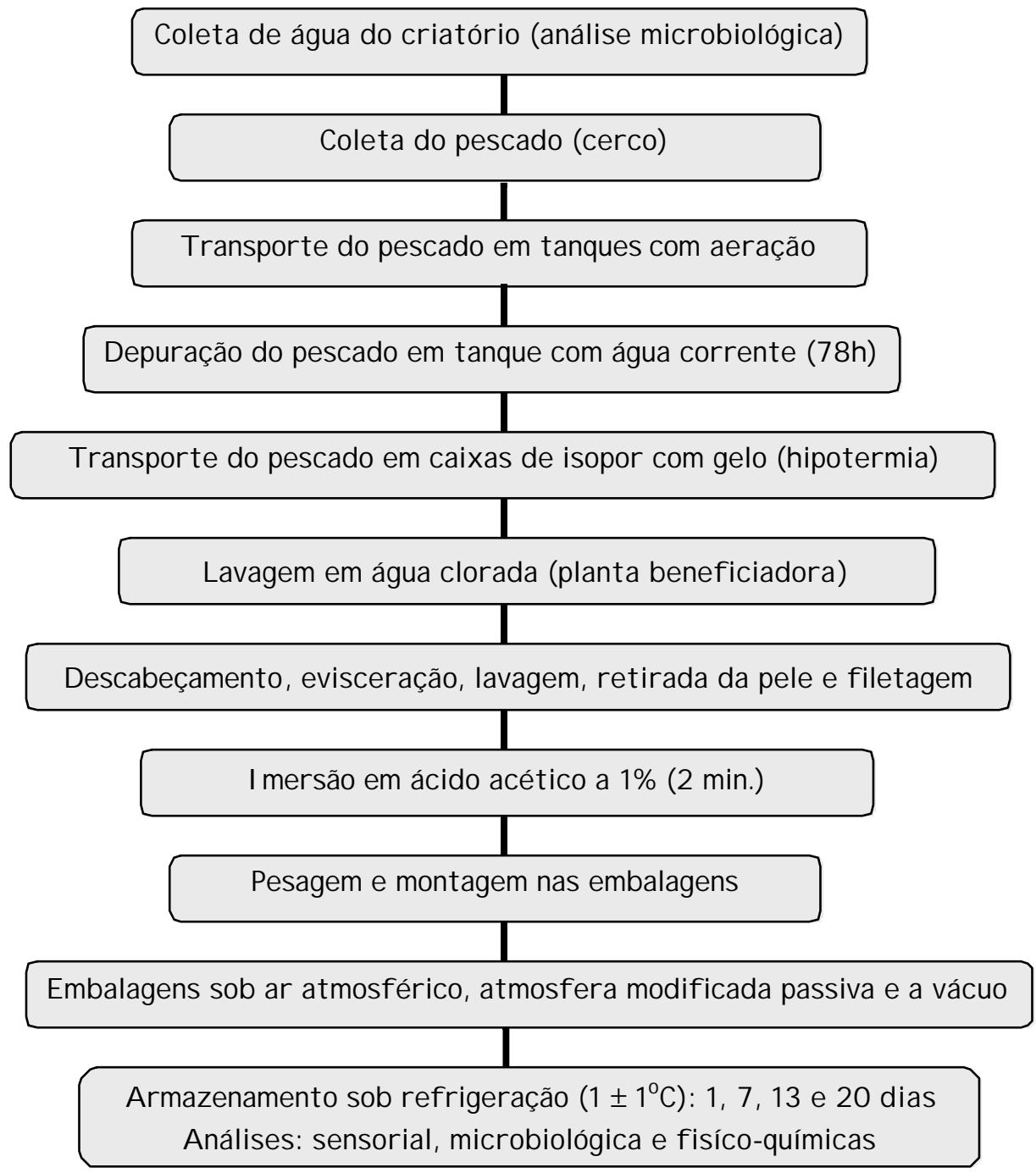

Figura 3 - Fluxograma de obtenção e análise do pescado minimamente processado.

\subsection{Tratamento químico dos filés}

Os peixes sofreram descabeçamento, evisceração, lavagem, retirada de pele e filetagem e foram colocados imediatamente em bandejas com gelo. Estas operações 
foram conduzidas em mesa processadora com utensílios para apoio de plástico rígido e para corte, de aço inoxidável por operadores munidos de luvas conforme pode-se observar na Figura 4. Parte dos filés foi submetida ao tratamento químico, por imersão em ácido acético a 1\%, na proporção 1,2: 1 , ou seja, $1,2 \mathrm{~kg}$ de pescado para $1 \mathrm{~L}$ de solução, a temperatura ambiente por 2 min. (Figura 4 (f)); a outra parte foi imersa em água destilada, nas mesmas condições, caracterizando a amostra controle. Em seguida os filés foram acondicionados em escorredores por 2 min. para permitir a drenagem da solução aplicada.

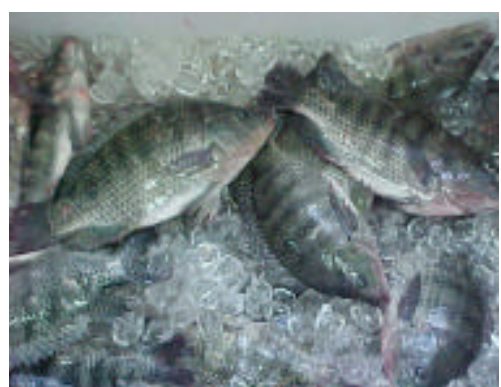

(a)

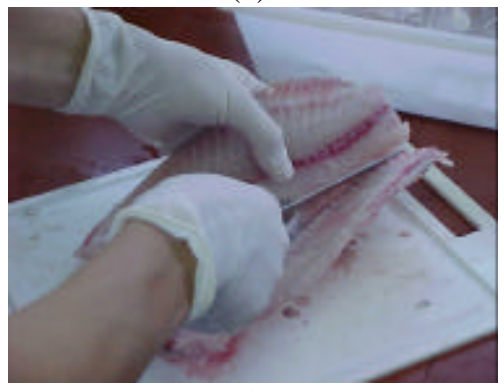

(d)

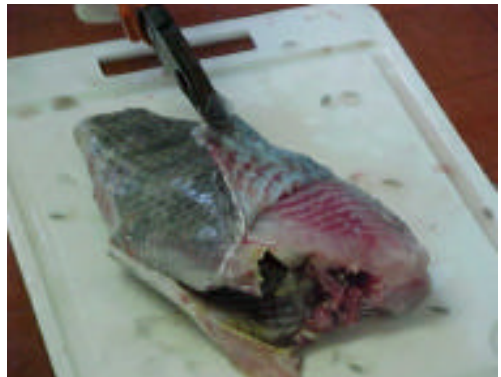

(b)

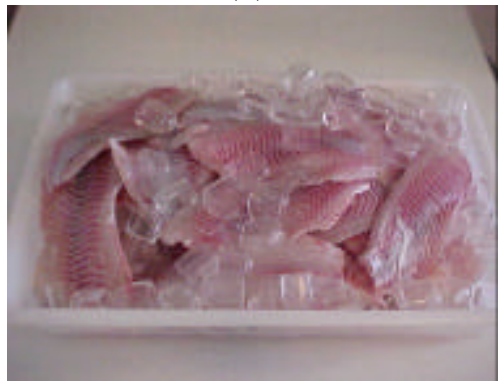

(e)

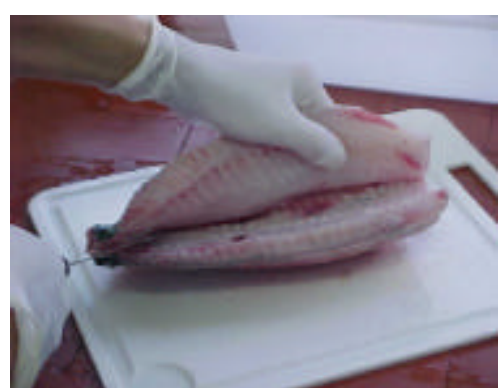

(c)

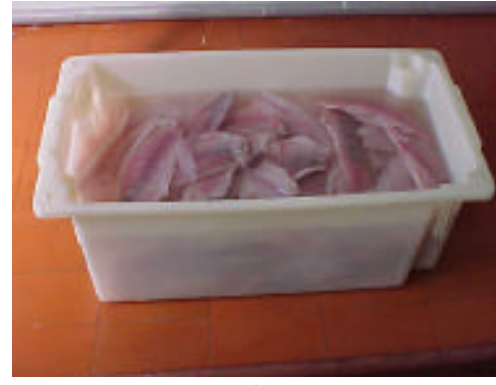

(f)

Figura 4 -Tilápias dispostas em caixas com gelo (a); retirada da pele (b); filetagem (c) e (d); filés dispostos em bandejas com gelo (e); filés imersos em solução de ácido acético a $1 \%$ (f).

\subsection{Montagem dos produtos nas embalagens}

Os filés foram acondicionados em bandejas de poliestireno e envolvidos por um filme plástico composto de etileno-álcool-vinílico - EVOH com espessura de 6,92 $\mu \mathrm{m}$ e taxa de permeabilidade ao $\mathrm{O}_{2}\left(\mathrm{TPO}_{2}\right)$ de $28,18 \mathrm{~cm}^{3} / \mathrm{m}^{2} /$ dia a $23^{\circ} \mathrm{C}, 80 \%$ UR e $1 \mathrm{~atm}$ de 
pressão; e em seguida procedeu-se o selamento térmico da embalagem sob ar atmosférico (controle). Outra partida recebeu o embalamento a vácuo, $635 \mathrm{~mm} \mathrm{Hg}$; a terceira seguiu embalamento sob atmosfera modificada, com $60 \%$ de $\mathrm{CO}_{2}+40 \%$ de $\mathrm{O}_{2}$, na proporção 2:1 (gás/peixe), ou seja, $1000 \mathrm{~mL}$ da mistura gasosa para $500 \mathrm{~g}$ de peixe, em seladora a vácuo AP-500, automática, da marca comercial TEC MAQ, como está demostrado na Figura 5.

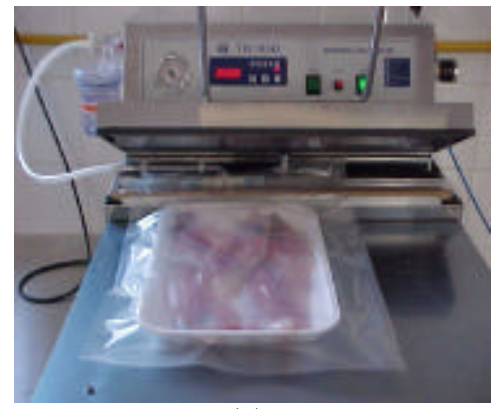

(a)

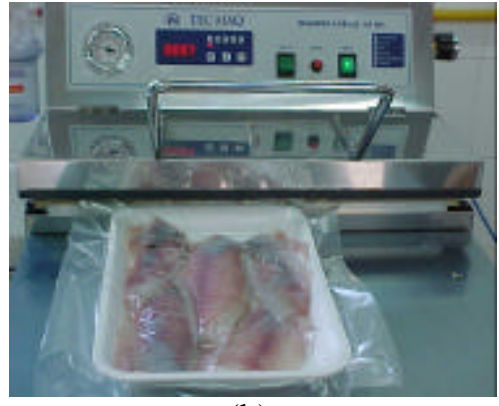

(b)

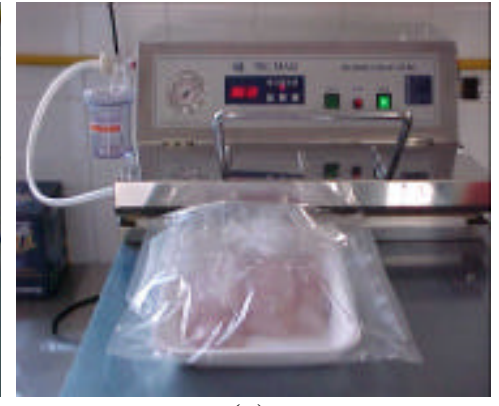

(c)

Figura 5 - Selamento térmico da embalagem sob ar atmosférico (controle) (a); evacuação do ar da embalagem (b); injeção da mistura gasosa na embalagem (c).

Nas Figuras de 6 a 11 estão apresentados os 6 produtos preparados com filés de tilápias. São os seguintes: filés de tilápia in natura, refrigerados e embalados em bandejas de poliestireno e filme plástico de $\mathrm{EVOH}$; filés de tilápia in natura, refrigerados e embalados sob atmosfera modificada; filés de tilápia in natura, refrigerados e embalados a vácuo; filés de tilápia in natura, acidificados, refrigerados e embalados em bandeja de poliestireno e filme plástico de EVOH; filés de tilápia in natura, acidificados, refrigerados e embalados sob atmosfera modificada e filés de tilápia in natura, acidificados, refrigerados e embalados a vácuo. 


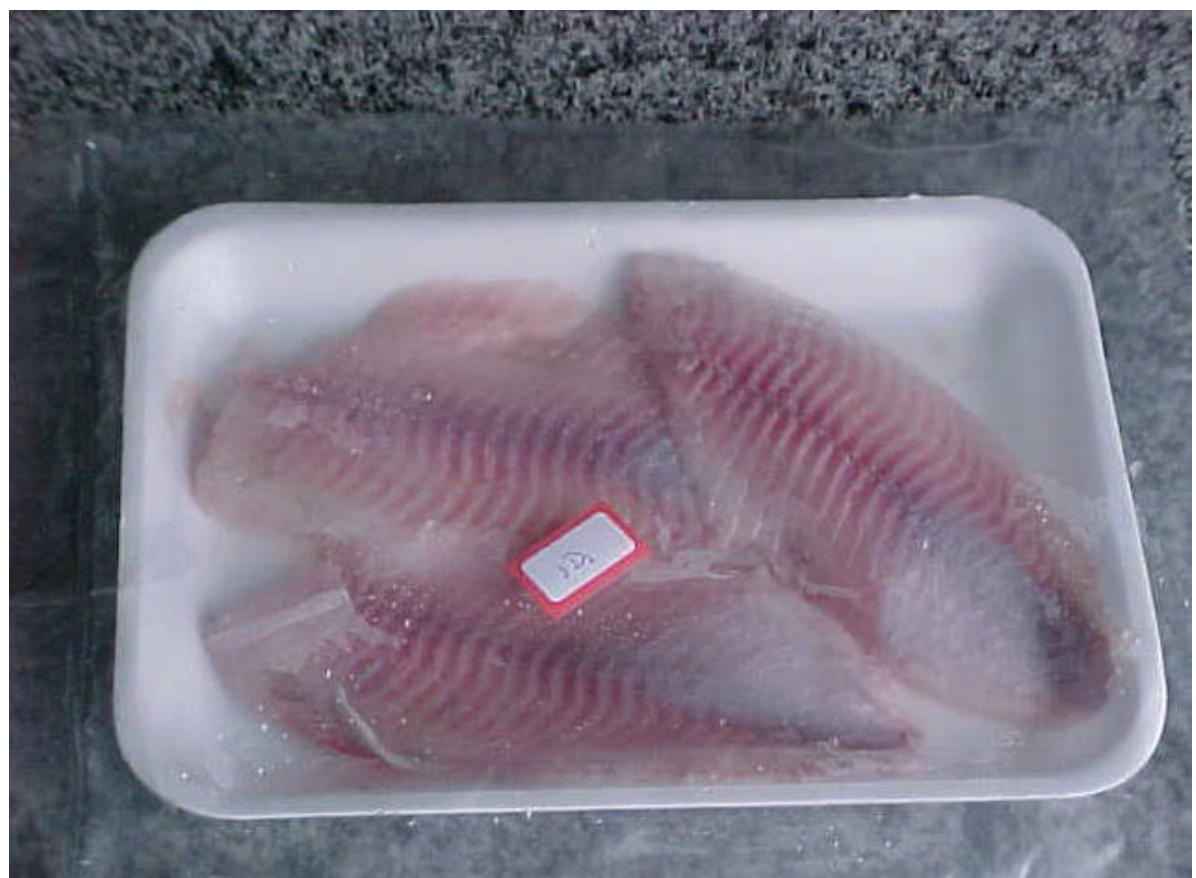

Figura 6 - Filés de tilápia in natura, refrigerados e embalados em bandejas de poliestireno e filme plástico de EVOH.

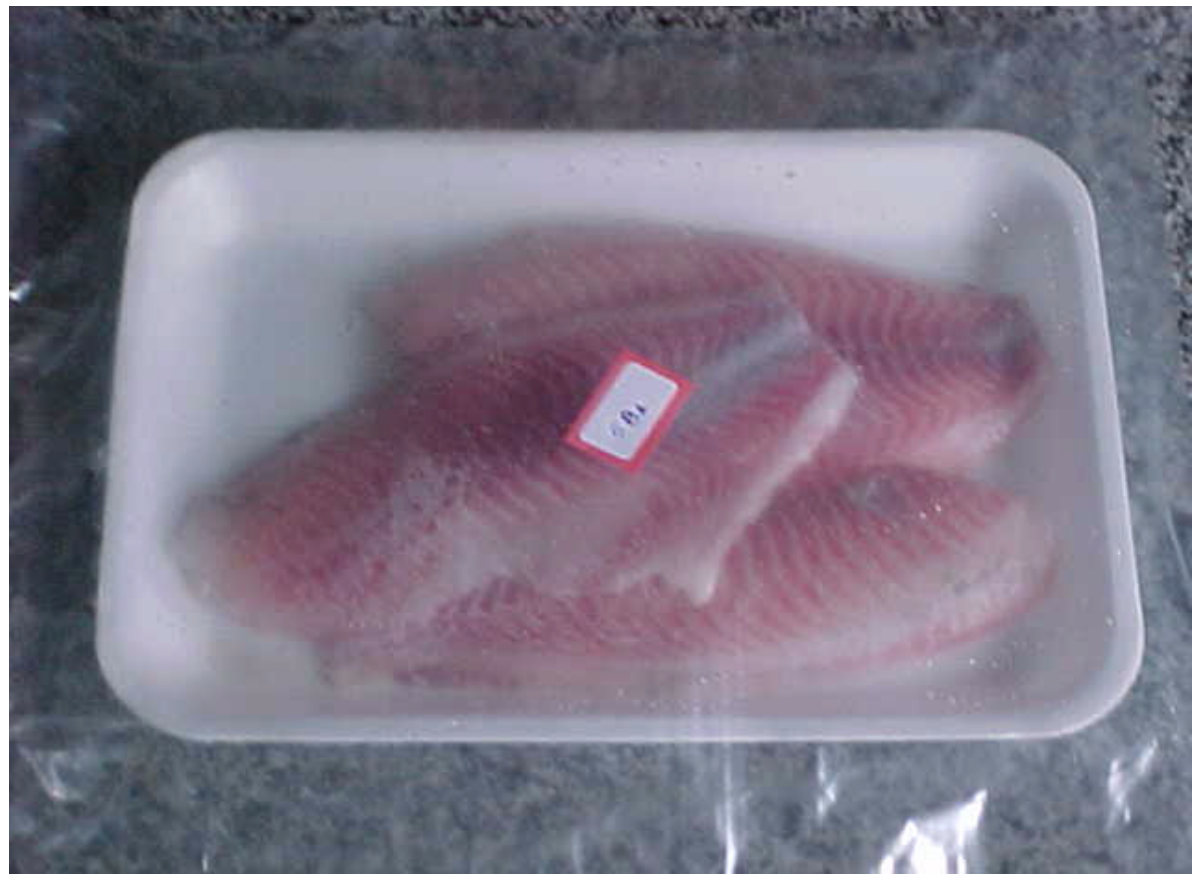

Figura 7 - Filés de tilápia in natura, refrigerados e embalados sob atmosfera modificada. 


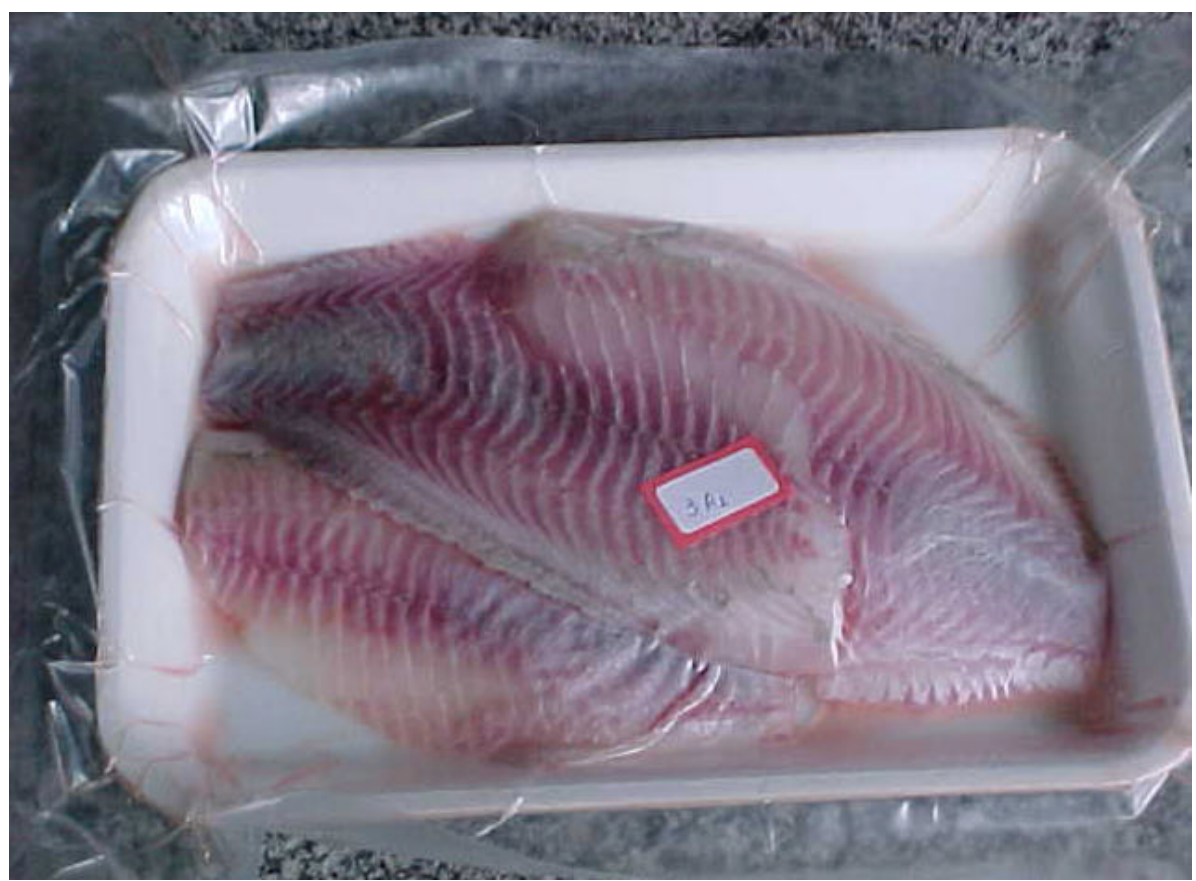

Figura 8 - Filés de tilápia in natura, refrigerados e embalados a vácuo.

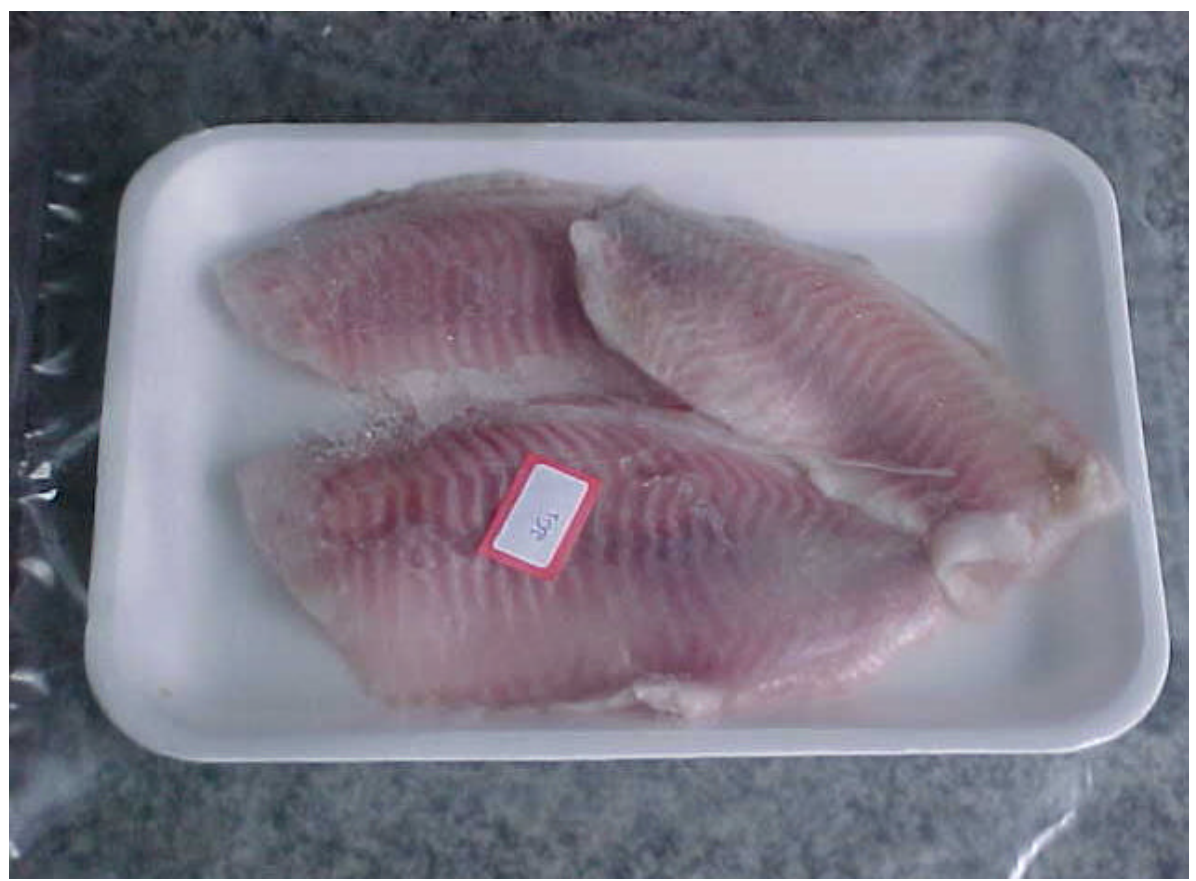

Figura 9 - Filés de tilápia in natura, acidificados, refrigerados e embalados em bandeja de poliestireno e filme plástico de EVOH. 


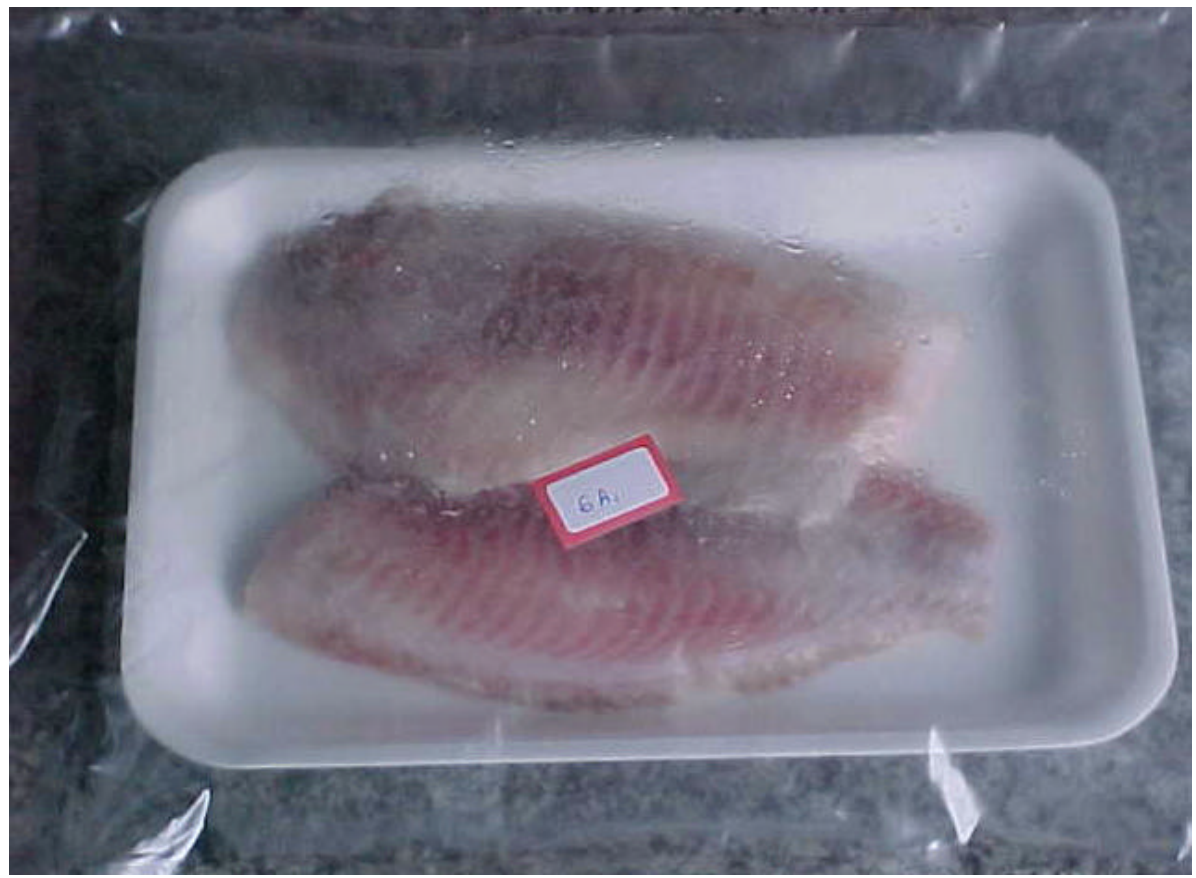

Figura 10 - Filés de tilápia in natura, acidificados, refrigerados e embalados sob atmosfera modificada.

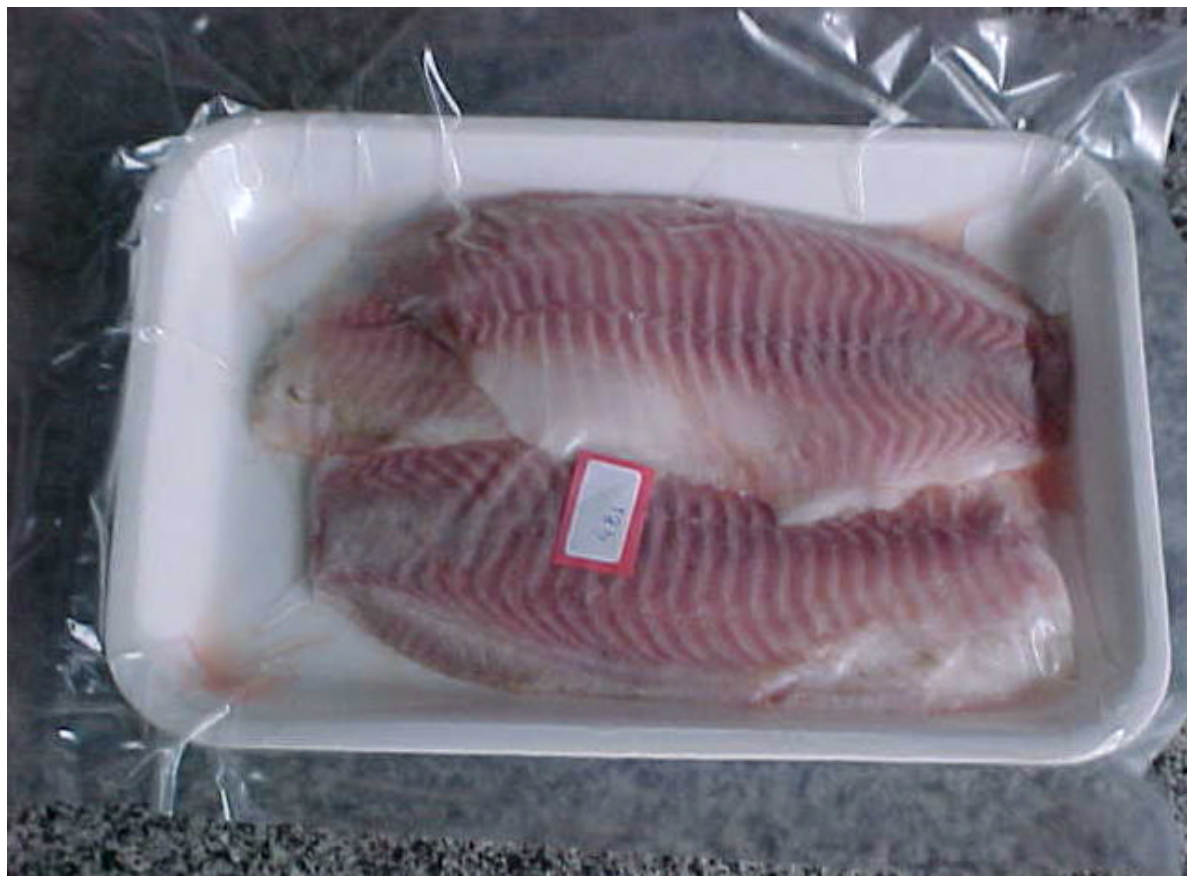

Figura 11 - Filés de tilápia in natura, acidificados, refrigerados e embalados a vácuo. 


\subsection{Refrigeração e armazenamento refrigerado}

Os produtos foram submetidos à refrigeração, a $1 \pm 1^{\circ} \mathrm{C}$, e armazenados por $1,7,13$ e 20 dias nestas condições.

\subsection{Análises microbiológicas}

As análises microbiológicas foram realizadas no $1^{\frac{0}{}}, 7^{\underline{0}}, 13^{\underline{0}}$ e $20^{\underline{0}}$ dias de armazenamento e foram conduzidas em triplicata para cada tratamento. As metodologias utilizadas para as análises convencionais seguiram as recomendações de Vanderzant \& Splittstoesser (1992) e Silva et al. (1997). Para as determinações microbiológicas utilizourse a técnica da enxaguadura, onde $100 \mathrm{~g}$ de filés de tilápia, com espessura de aproximadamente $0,5 \mathrm{~cm}$ foram misturadas com $100 \mathrm{~mL}$ de água peptonada tamponada (1:1) e submetidos à agitação. Assim, cada $\mathrm{mL}$ pipetado desta enxaguadura correspondia

a $1 \mathrm{~g}$ de peixe. As diluições $10^{-1}$ a $10^{-4}$ foram preparadas diluindo-se $10 \mathrm{~mL}$ da amostra em $90 \mathrm{~mL}$ de água peptonada $0,1 \%$ esterilizada. Os microrganismos de interesse foram:

\subsubsection{Clostridium sulfito-redutores}

Foram utilizadas placas com meio Agar Triptose-Sulfito Cicloserina (TSC), inoculadas com $1 \mathrm{~mL}$ da enxaguadura e $10^{-1}$ e incubadas a $46^{\circ} \mathrm{C}$ por $24-48 \mathrm{~h}$, anaerobiose, utilizando jarra com Anaerobac (Probac). Após o período de incubação fezse a leitura com auxílio de uma lupa, em um contador de colônias tipo Quebec.

\subsubsection{Coliformes totais e Escherichia coli}

A contagem de coliformes totais e E. coli foi feita através do sistema "Simplate Test Procedures", que utiliza kits compostos por placas descartáveis, contendo 84 cavidades em cada placa e substratos apropriados para cada microrganismo. Esta metodologia recebeu o certificado de aprovação da AOAC 97030/ de 05/03/97 e do DIPOA n. 29/97.

As placas foram inoculadas com $1 \mathrm{~mL}$ da enxaguadura e $10^{-1}$ em $9 \mathrm{~mL}$ do meio e agitadas em movimentos circulares. O excesso foi descartado, e as placas invertidas e incubadas a $35^{\circ} \mathrm{C}$ por $24 \mathrm{~h}$. Após o período de incubação fez-se a leitura na câmara de luz 
ultravioleta, de $365 \mathrm{~nm}$ de comprimento de onda. Do valor obtido na contagem das cavidades positivas, determinou-se o NMP de coliformes totais e E. coli por $\mathrm{g}$ de pescado, consultando-se a Tabela que acompanha o kit.

\subsubsection{Salmonella spp.}

Para a detecção presuntiva de Salmonella, utilizoutse o kit "Oxoid Salmonella Rapid Test” (FT 201-A da Oxoid), com certificado de aprovação pela AOAC 960902 de $11 / 12 / 96$.

Foi realizado um pré-enriquecimento de cada amostra analisada, inoculando-se $25 \mathrm{~g}$ de pescado em um erlenmeyer contendo $225 \mathrm{~mL}$ de água peptonada tamponada esterilizada. Os frascos foram incubados a temperatura de $35 \pm 2{ }^{\circ} \mathrm{C}$ por $24 \mathrm{~h}$. Após o período de incubação, transferiu-se $1 \mathrm{~mL}$ da amostra pré-enriquecida e incubou-se o kit a $41{ }^{\circ} \mathrm{C}$ por $24 \mathrm{~h}$. Para a confirmação da presença de Salmonella foi realizado o teste sorológico, utilizando-se o Latex Test (polyvalent latex agglutination/FT203-A da Oxoid).

\subsubsection{Staphylococcus aureus}

Para a análise de S. aureus foram utilizadas placas com meio Agar Baird-Parker (BPA), através do espalhamento do inóculo na superfície, com a alça de Drigalsky. Da diluição $10^{-1}$ espalhou-se $1 \mathrm{~mL}$ em três placas com o meio $(0,3 ; 0,3$ e $0,4 \mathrm{~mL})$. Ainda a partir da diluição $10^{-1}$ espalhou-se $0,1 \mathrm{~mL}$; o mesmo procedimento foi adotado para a diluição $10^{-2}$. Após a absorção do inóculo, as placas foram invertidas e incubadas a $35-37^{\circ} \mathrm{C}$ por $24-48 \mathrm{~h}$. Após este período, procedeu-se a contagem das colônias típicas (pretas, pequenas, lisas e com halo). Para a confirmação das colônias típicas foram realizados: coloração de Gram, provas de catalase e coagulase.

\subsubsection{Psicrotróficos}

Foram utilizadas placas com meio Agar Padrão para Contagem (PCA), inoculadas com $1 \mathrm{~mL}$ da enxaguadura a $10^{-4}$ e agitadas em movimentos circulares. As 
placas foram invertidas e incubadas a $7^{\circ} \mathrm{C}$ por 10 dias. Após o período de incubação fezse a leitura com auxílio de uma lupa, em um contador de colônias tipo Quebec.

\subsubsection{Coliformes totais e Escherichia coli em água}

As análises para coliformes totais e E. coli foram realizadas através do sistema colilert para água bruta. Para o teste foi utilizado 3 séries de 5 tubos com 10, 1 e $0,1 \mathrm{~mL}$ da água bruta juntamente com $10 \mathrm{~mL}$ de água destilada esterilizada contendo os substratos hidrolizáveis, cromogênico ONPG (orto-nitrofenil-B-D-galactopiranosídeo) e fluorogênico MUG (4-metilumbeliferil B-D-glucoronídeo). Os tubos foram incubados a $35-37^{\circ} \mathrm{C}$, por $24-48 \mathrm{~h}$. Após esse período de incubação fez-se a leitura. Os tubos que desenvolveram uma coloração amarela foram considerados positivos para coliformes totais. Destes, os que fluoresceram sob luz ultravioleta de $365 \mathrm{~nm}$ de comprimento de onda, foram considerados positivos para E. coli. Após consulta a Tabela de NMP para a coliformes em água, determinou-se o NMP de coliformes totais e E. coli por $100 \mathrm{~mL}$ de água.

\subsection{Análises físico-químicas}

As análises físico-químicas foram as seguintes:

\subsubsection{Composição centesimal}

3.7.1.1 Umidade: determinada por perda de peso da amostra em estufa aquecida a $105 \pm$ $1^{\circ} \mathrm{C}$, até o peso constante, de acordo com Association of Official Analytical Chemists AOAC (1995).

3.7.1.2 Proteína bruta: mediante a determinação do nitrogênio total, pelo método Kjeldahl, e conversão em proteína multiplicando o valor obtido pelo fator 6,25, de acordo com AOAC (1995).

3.7.1.3 Lipídeos: determinados através do método de Soxhlet, utilizando hexano como solvente extrator, conforme descrito pela AOAC (1995). 
3.7.1.4 Cinza: por incineração da matéria orgânica, em forno mufla a $550^{\circ} \mathrm{C}$, até o peso constante, de acordo com AOAC (1995).

3.7.2 Nitrogênio não protéico (NNP): determinado por precipitação das proteínas musculares com ácido tricloroacético (TCA), seguida de avaliação do nitrogênio não protéico presente no extrato TCA, através do método Micro Kjeldhal, de acordo com AOAC (1995).

3.7.3 Bases nitrogenadas voláteis totais (BNVT): determinada por meio de precipitação protéica com ácido tricloroacético (TCA), e destilação de alíquotas de 20 $\mathrm{mL}$ do filtrado com recebimento do destilado em ácido bórico a $1 \%$ com indicador misto, e sua titulação com ácido clorídrico 0,02 N, conforme descrito por Morga (1975).

3.7.4 Determinação da reação ao ácido tiobarbitúrico (TBARS): determinada por precipitação das proteínas ligadas aos lipídeos e fosfolípideos com adição de $\mathrm{HCl}$ e água destilada (1:2) até a obtenção de pH 1,5; destilação e adição do reagente TBA que promoverá a condensação do malonaldeído presente no destilado. Leitura em espectrofotômetro a $535 \mathrm{~nm}$ e conversão de $\mathrm{mg}$ de malonaldeído para $\mathrm{kg}$ de alimento pelo fator 7,8, segundo Tarladgis et al. (1960). Os valores de TBA foram comparados com 2 curvas de porcentagem de malonaldeído, com e sem a presença da amostra.

3.7.5 Determinação de $\mathbf{p H}$ : em potenciômetro digital Digimed, utilizando o músculo homogeneizado em água destilada, na proporção 1:1.

3.7.6 Determinação de pH da água: leitura direta em potenciômetro digital Digimed.

3.7.7 Determinação da condutividade elétrica da água: leitura direta em condutivímetro digital Marconi. 
3.7.8 Determinação de aminoácidos totais: com analisador de aminoácidos, segundo Spackman et al. (1958).

3.7.9 Determinação de ácidos graxos: em cromatografia gasosa, segundo Firestone (1998).

\subsection{Análise sensorial}

A análise sensorial foi realizada de acordo com Dutcosky (1996). Os filés foram submetidos à observação sensorial através de uma equipe formada por 30 provadores, sendo 10 provadores por bloco, utilizando a ficha de avaliação descrita na Figura 12.

Para a medida da intensidade dos atributos (cor, aroma, textura e aparência), foi utilizada uma escala estruturada variando de gostei extremamente (nota 9) a desgostei extremamente (nota 1). As amostras foram apresentadas aos provadores em pratos de cerâmica, recobertos com filme de PVC esticável, codificados com números de 3 dígitos selecionados aleatoriamente, como pode-se observar na Figura 13. O delineamento experimental adotado foi em blocos incompletos com 5 repetições e 3 amostras por bloco, constituindo cada bloco um provador, conforme Cochran \& Cox (1964).

\subsection{Acompanhamento do processamento e análise estatística}

O acompanhamento do processamento mínimo foi realizado periodicamente através das análises microbiológicas, físico-químicas e sensoriais, no $1^{\underline{0}}$ dia de experimento e aos 7, 13 e 20 dias de armazenamento refrigerado; aminoácidos e ácidos graxos no $1^{0}$ dia de experimento e aos 20 dias.

O delineamento experimental adotado foi fatorial $6 \times 4 \times 3$ blocos casualizados, referentes aos 6 tratamentos, 4 períodos de armazenamento e 3 blocos, onde se estudaram as variáveis, tratamentos, tempo de armazenamento e interação entre os fatores. Os dados obtidos foram submetidos à análise de variância (PROC GLM) através do programa SAS 8.0 (1999). As médias foram comparadas entre si pelo teste de Tukey, a $5 \%$ de probabilidade. 


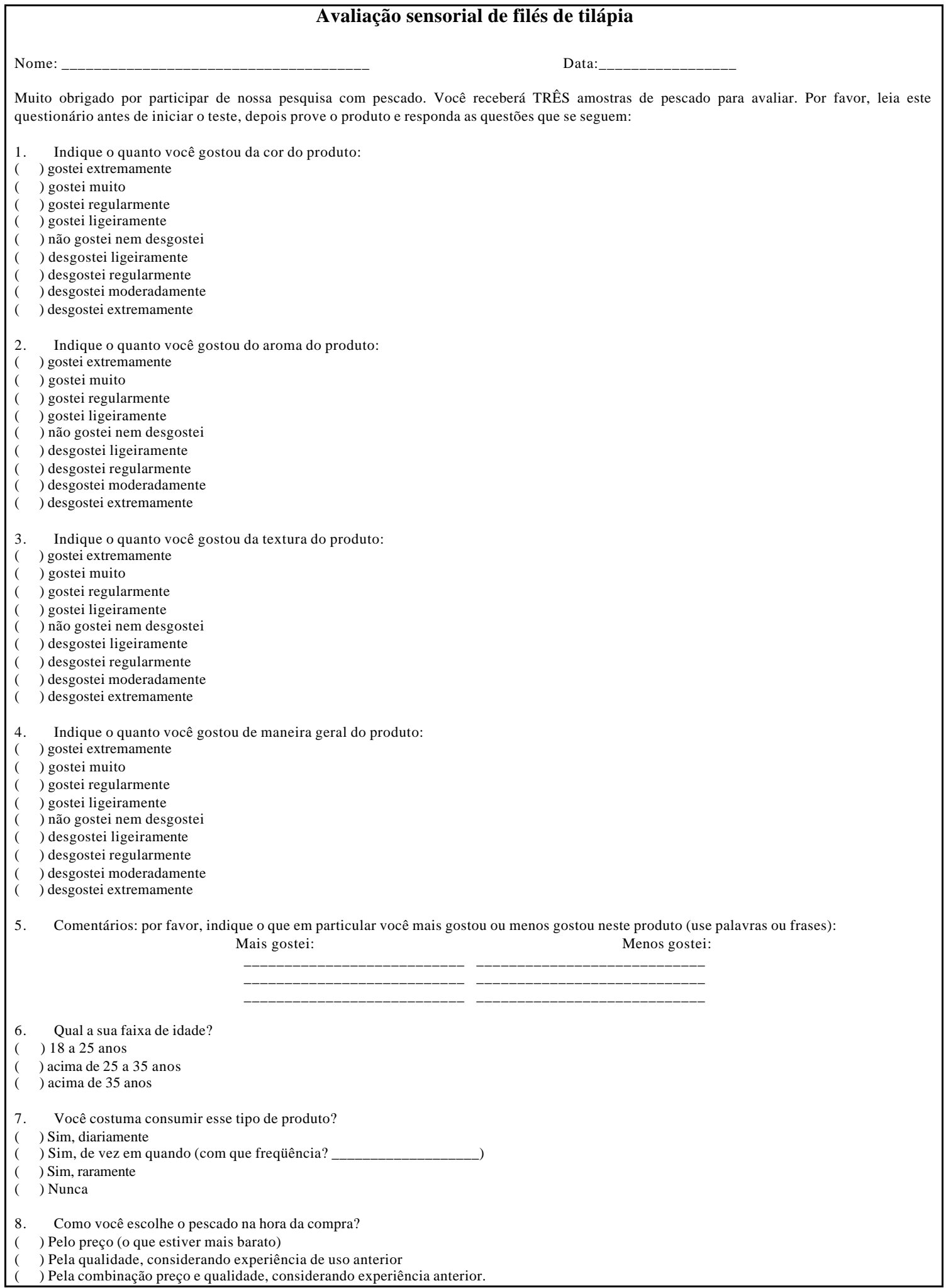

Figura 12 - Ficha de avaliação sensorial das amostras de filés de tilápia. 


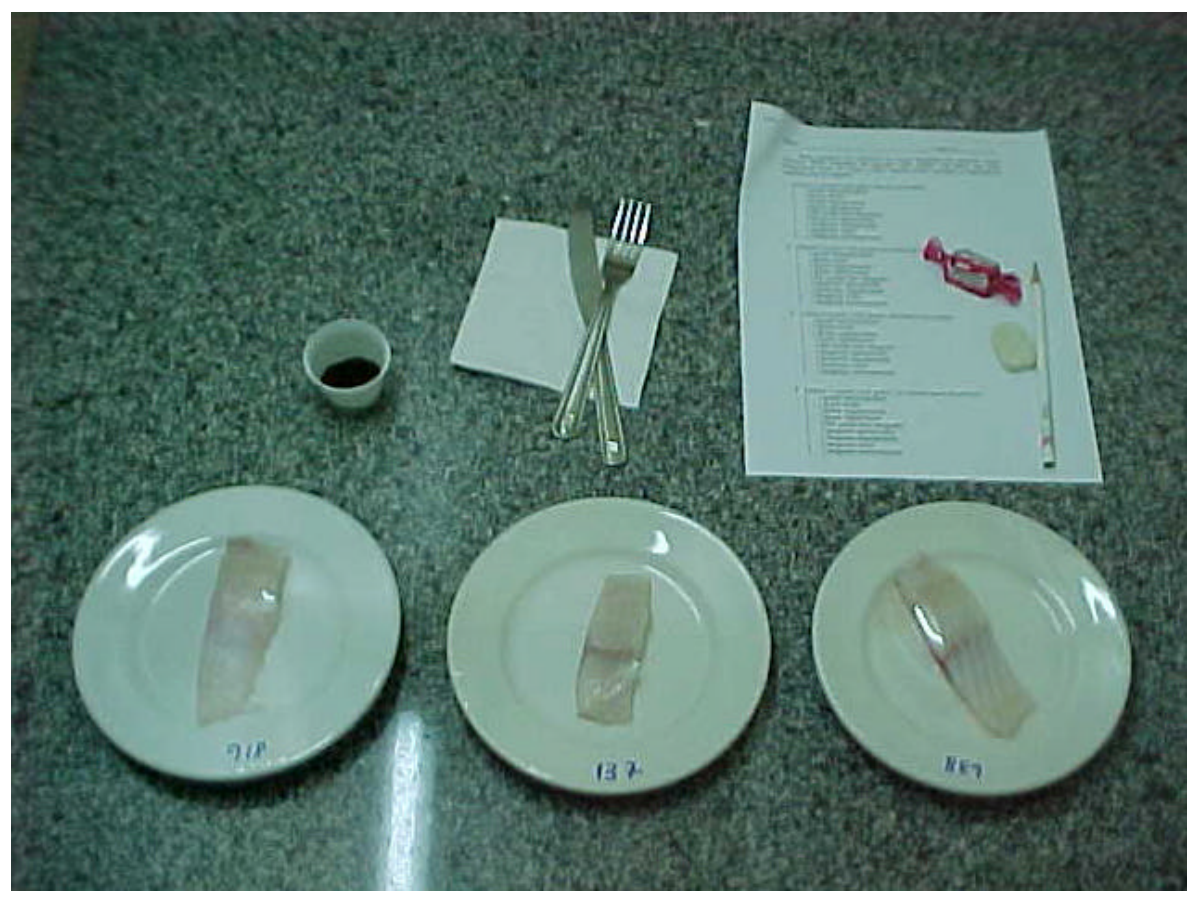

Figura 13 - Disposição das amostras em cabines sensoriais. 


\section{RESULTADOS E DISCUSSÃO}

\subsection{Análises físico-químicas}

\subsubsection{Composição centesimal}

\subsubsection{Umidade}

A Tabela 1 e a Figura 14 apresentam a variação da umidade em filés de tilápia durante o período de armazenamento. Os valores de umidade não foram afetados significativamente (Teste F) pelos tratamentos e pelo período de armazenamento. Os valores médios para umidade variaram de 76,62 a 79,02 g/100g, estando de acordo com aqueles encontrados por Ferreira (1987), Mujica (1988), Akande (1989), ContrerasGuzmán (1994) e Lima \& Zapata (1998) que foram de 76 a 83,10 g/100g.

Tabela 1. Umidade $(\mathrm{g} / 100 \mathrm{~g})$ em filés de tilápia mantidos sob refrigeração a $1 \pm 1^{\circ} \mathrm{C}$, durante 20 dias.

\begin{tabular}{ccccccc}
\hline \multirow{2}{*}{\begin{tabular}{c} 
Armazenamento $\begin{array}{c}\text { Tratamentos } \\
\text { (Dias) }\end{array}$ \\
\cline { 2 - 7 }
\end{tabular}} & Controle & $\begin{array}{c}\text { Ácido } \\
\text { Acético }\end{array}$ & Vácuo & $\begin{array}{c}\text { Vácuo + Ác. } \\
\text { Acético }\end{array}$ & EAM & $\begin{array}{c}\text { EAM + Ác. } \\
\text { Acético }\end{array}$ \\
\hline 1 & 78,63 & 78,84 & 79,02 & 77,13 & 78,44 & 77,79 \\
7 & 77,09 & 78,13 & 78,12 & 77,04 & 77,24 & 78,18 \\
13 & 78,11 & 78,14 & 77,22 & 77,44 & 76,91 & 77,23 \\
20 & 76,62 & 76,91 & 78,25 & 78,07 & 77,78 & 76,80 \\
\hline
\end{tabular}

EAM: Embalagem sob atmosfera modificada com $60 \% \mathrm{CO}_{2}+40 \% \mathrm{O}_{2} ; \mathrm{F} /$ Armazenamento= 1,26 n.s.; F/Tratamento= 0,44 n.s.; F/Interação= 0,52 n.s.; C.V.=1,99\%. 


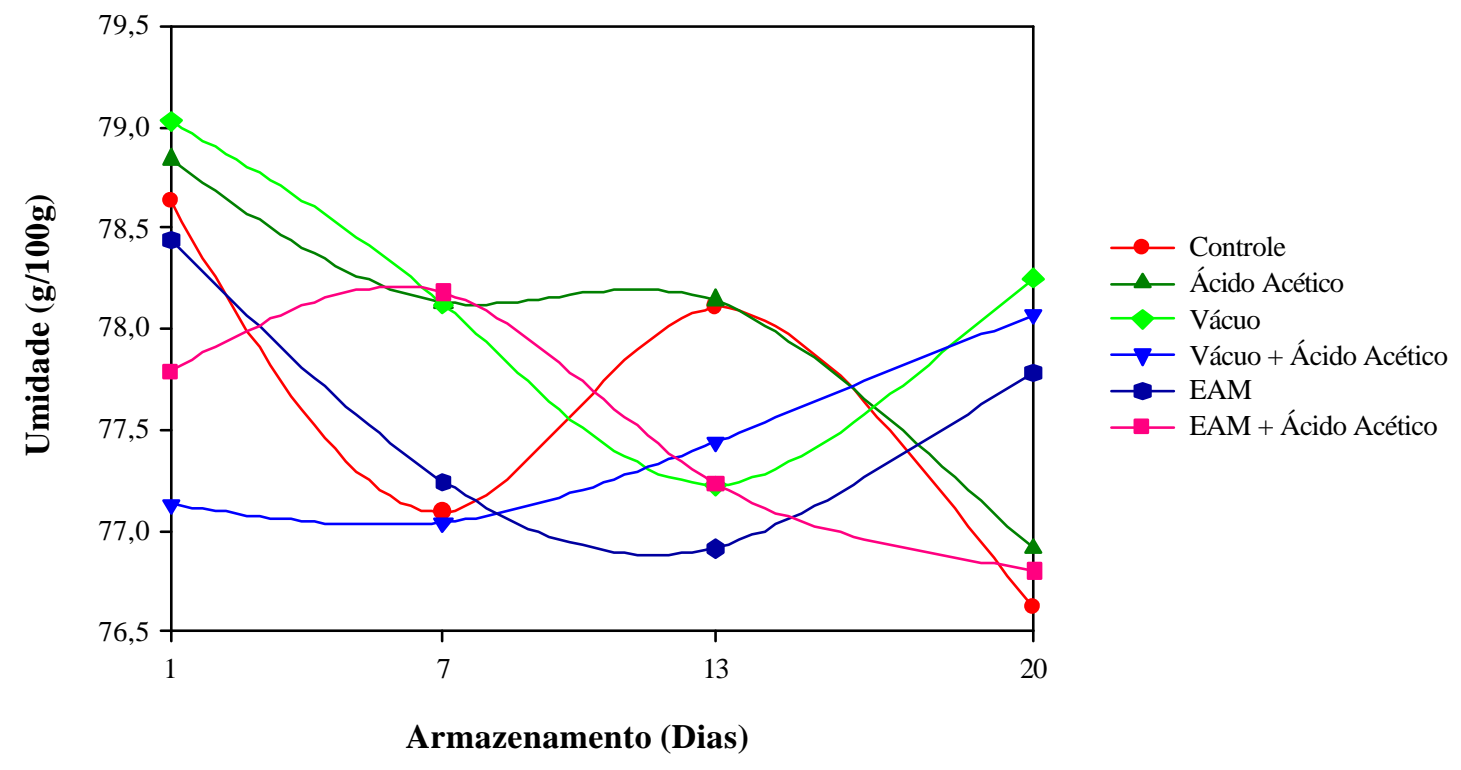

Figura 14 - Umidade em filés de tilápia mantidos sob refrigeração a $1 \pm 1^{\circ} \mathrm{C}$, durante 20 dias.

O pescado magro apresenta um alto teor de umidade, podendo atingir $83 \mathrm{~g} / 100 \mathrm{~g}$, ao contrário do pescado gordo, que pode apresentar no mínimo 58 g/100g de umidade (Sikorski, 1990).

Para os tratamentos a vácuo e EAM foi observado um decréscimo de umidade até o $12^{\underline{o}}$ dia de armazenamento, condizendo com os resultados observados por Hong et al. (1996) para a cavala do Atlântico (Scomber scombrus), armazenada em EAM contendo 60 a $70 \%$ de $\mathrm{CO}_{2}$ a $-2{ }^{\circ} \mathrm{C}$, que também apresentou um decréscimo no conteúdo de umidade de 77,84 para 75,35 g/100g, até o 14ํㅡ dia de armazenamento.

\subsubsection{Proteína}

Para proteína, os tratamentos e o período de armazenamento não foram significativos (Teste F) como pode-se observar na Tabela 2 e na Figura 15. Os valores médios variaram de 15,60 a 17,90 g/100g e estão de acordo com os apresentados por 
Soccol et al. (2002) para a mesma espécie, da ordem de 15 a 18 g/100g.

Segundo Stansby (1962) é possível classificar a tilápia do Nilo na categoria de pescado de alto teor protéico e baixo teor de gordura, sendo os teores de proteína comparáveis aos de outras carnes, como bovina, suína e ovina.

Tabela 2. Proteína (g/100g) em filés de tilápia mantidos sob refrigeração a $1 \pm 1^{\circ} \mathrm{C}$, durante 20 dias.

\begin{tabular}{ccccccc}
\hline \multirow{2}{*}{$\begin{array}{c}\text { Armazenamento } \\
\text { (Dias) }\end{array}$} & Controle & $\begin{array}{c}\text { Ácido } \\
\text { Acético }\end{array}$ & Vácuo & $\begin{array}{c}\text { Vácuo + Ác. } \\
\text { Acético }\end{array}$ & EAM & $\begin{array}{c}\text { EAM + Ác. } \\
\text { Acético }\end{array}$ \\
\cline { 2 - 7 } & 16,73 & 16,01 & 15,60 & 17,03 & 16,47 & 17,23 \\
7 & 17,51 & 17,29 & 15,90 & 17,90 & 17,05 & 16,27 \\
13 & 16,54 & 16,48 & 17,83 & 16,74 & 17,69 & 17,63 \\
20 & 17,71 & 17,55 & 17,04 & 16,52 & 16,63 & 17,46 \\
\hline
\end{tabular}

EAM: Embalagem sob atmosfera modificada com $60 \% \mathrm{CO}_{2}+40 \% \mathrm{O}_{2} ;$ F/Armazenamento $=1,19$ n.s.; $\mathrm{F} /$ Tratamento $=0,38$ n.s.; F/Interação $=1,02$ n.s.; C.V. $=6,93 \%$.

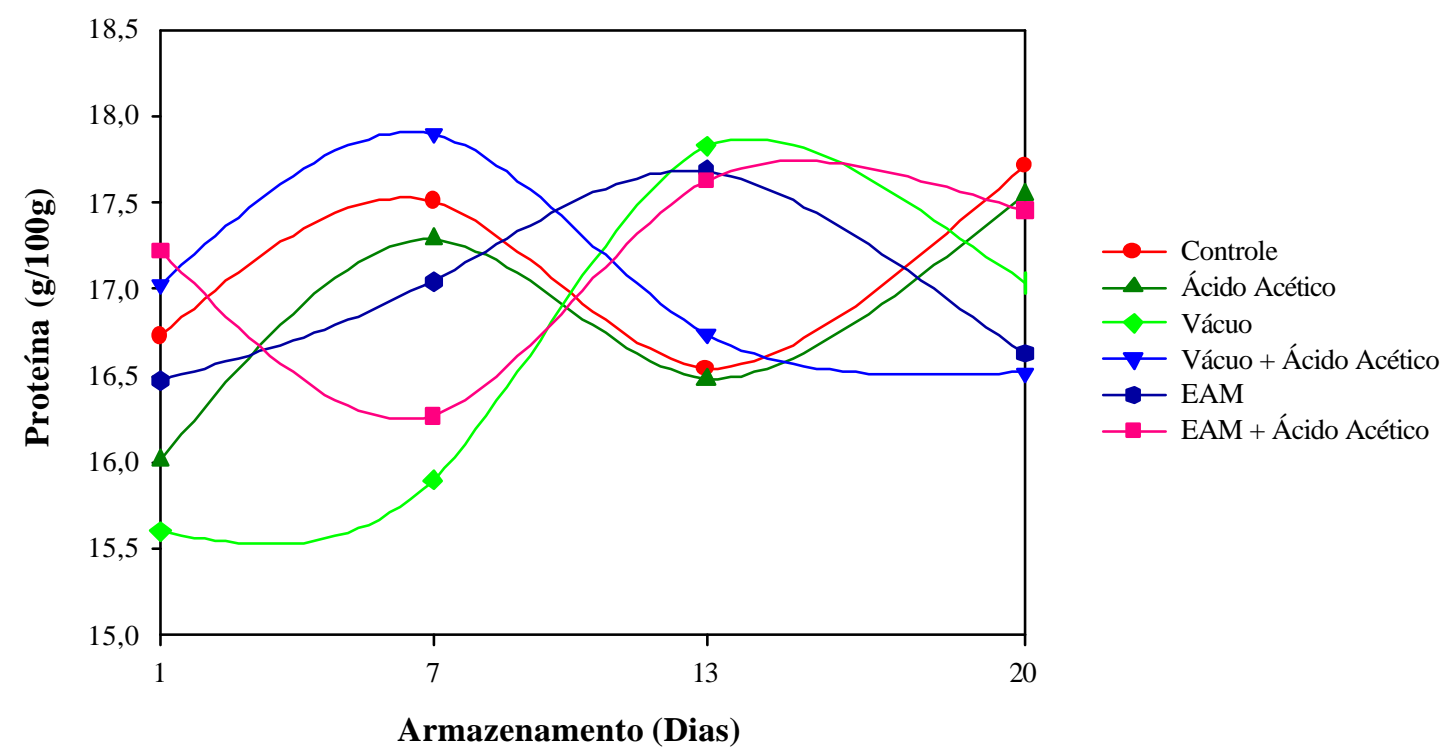

Figura 15 - Proteína em filés de tilápia mantidos sob refrigeração a $1 \pm 1{ }^{\circ} \mathrm{C}$, durante 20 dias. 


\subsubsection{Lipídeos}

Em relação ao teor de lipídeos, os valores médios variaram de 2,80 a 3,62 g/100g, estando um pouco superiores aos valores encontrados por Ferreira (1987) e Mujica (1988) que foram de 2,2 a 2,4 g/100g. Essa variação pode ocorrer devido à idade, sexo, maturidade sexual, regime alimentar e estação sazonal.

Os diferentes tratamentos e os períodos de armazenamento não apresentaram diferenças significativas entre si (Teste F) como pode-se observar na Tabela 3 e na Figura 16.

Stansby (1962) descreveu os seguintes intervalos do teor de gordura para comparação entre espécies: gordos apresentam mais de $15 \%$ de gordura; semigordos, de 5 a $15 \%$ de gordura; magros, menos de $5 \%$ de gordura.

Tabela 3. Lipídeos (g/100g) em filés de tilápia mantidos sob refrigeração a $1 \pm 1^{\circ} \mathrm{C}$, durante 20 dias.

\begin{tabular}{ccccccc}
\hline \multirow{2}{*}{\begin{tabular}{c} 
Armazenamento $\begin{array}{c}\text { Tratamentos } \\
\text { (Dias) }\end{array}$ \\
\cline { 2 - 7 }
\end{tabular}} & Controle & $\begin{array}{c}\text { Ácido } \\
\text { Acético }\end{array}$ & Vácuo & $\begin{array}{c}\text { Vácuo + Ác. } \\
\text { Acético }\end{array}$ & EAM & $\begin{array}{c}\text { EAM + Ác. } \\
\text { Acético }\end{array}$ \\
\hline 1 & 3,05 & 3,04 & 2,90 & 3,62 & 2,95 & 3,34 \\
7 & 3,42 & 2,81 & 2,88 & 3,54 & 2,94 & 3,71 \\
13 & 3,14 & 3,17 & 2,85 & 3,44 & 2,80 & 3,40 \\
20 & 3,52 & 3,36 & 3,08 & 3,21 & 2,95 & 3,62 \\
\hline
\end{tabular}

EAM: Embalagem sob atmosfera modificada com $60 \% \mathrm{CO}_{2}+40 \% \mathrm{O}_{2} ; \mathrm{F} /$ Armazenamento $=0,17$ n.s.; F/Tratamento $=1,50$ n.s.; F/Interação= 0,17 n.s.; C.V. $=23,11 \%$. 


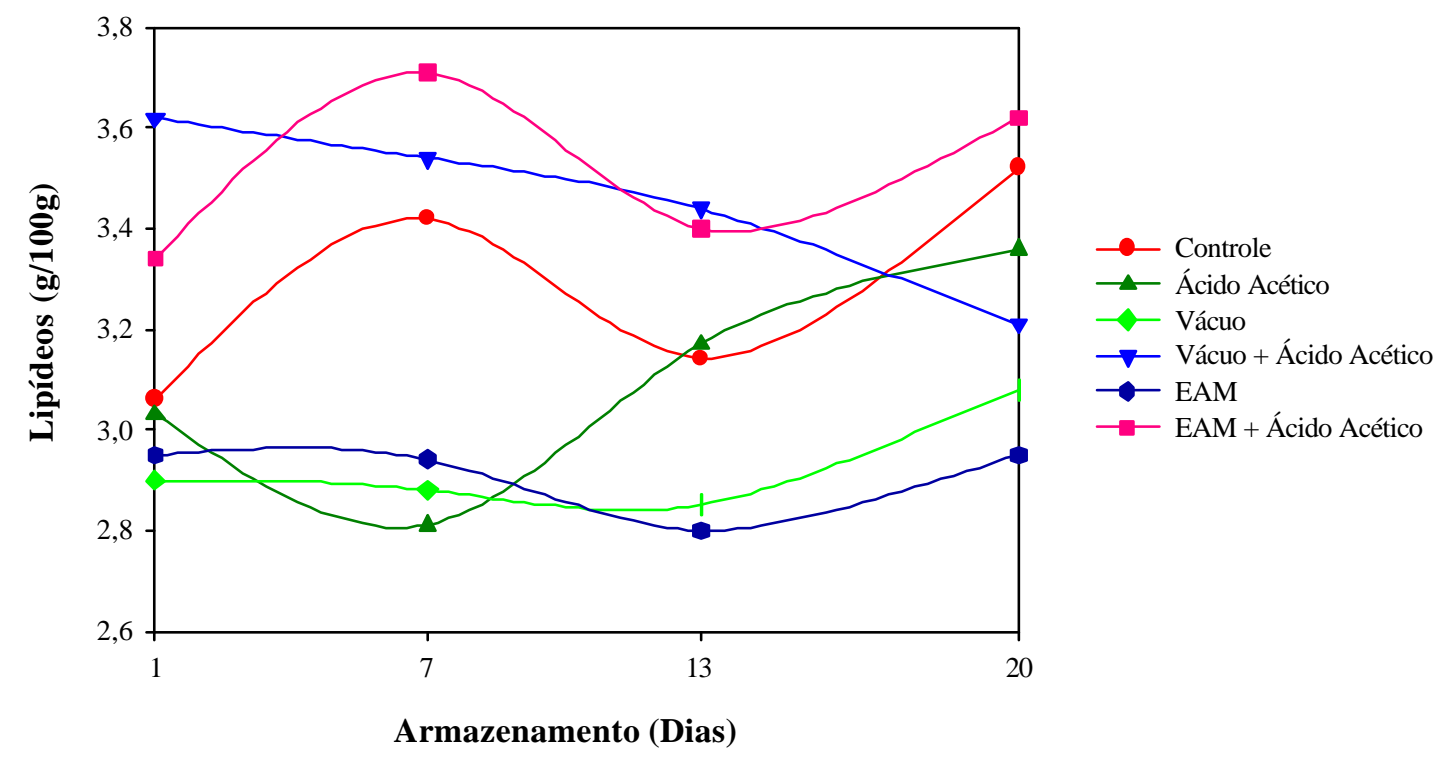

Figura 16 - Lipídeos em filés de tilápia mantidos sob refrigeração a $1 \pm 1^{\circ} \mathrm{C}$, durante 20 dias.

\subsubsection{Cinza}

A fração cinza dos filés de tilápia não foi afetada significativamente (Teste F) pelos tratamentos e pelo período de armazenamento como pode-se observar na Tabela 4 e na Figura 17. Os valores médios variaram de 0,86 a 1,01g/100g, estando de acordo com os valores relatados por Lima \& Zapata (1998) e Soccol et al. (2002) que foram de 0,84 a $1,23 \mathrm{~g} / 100 \mathrm{~g}$. 
Tabela 4. Cinza $(\mathrm{g} / 100 \mathrm{~g})$ em filés de tilápia mantidos sob refrigeração a $1 \pm 1^{\circ} \mathrm{C}$, durante 20 dias.

\begin{tabular}{ccccccc}
\hline \multirow{2}{*}{\begin{tabular}{c} 
Armazenamento $\begin{array}{c}\text { Tratamentos } \\
\text { (Dias) }\end{array}$ \\
\cline { 2 - 7 }
\end{tabular}} & Controle & $\begin{array}{c}\text { Ácido } \\
\text { Acético }\end{array}$ & Vácuo & $\begin{array}{c}\text { Vácuo + Ác. } \\
\text { Acético }\end{array}$ & EAM & $\begin{array}{c}\text { EAM + Ác. } \\
\text { Acético }\end{array}$ \\
\hline 1 & 0,91 & 0,89 & 0,86 & 0,91 & 0,98 & 0,92 \\
7 & 0,96 & 0,96 & 0,93 & 0,93 & 0,94 & 0,87 \\
13 & 0,89 & 0,90 & 0,96 & 0,95 & 1,00 & 0,92 \\
20 & 1,01 & 0,99 & 0,95 & 0,90 & 0,96 & 0,87 \\
\hline
\end{tabular}

EAM: Embalagem sob atmosfera modificada com $60 \% \mathrm{CO}_{2}+40 \% \mathrm{O}_{2} ; \mathrm{F} /$ Armazenamento $=0,63$ n.s.; F/Tratamento $=1,12$ n.s.; F/Interação $=0,78$ n.s.; C.V. $=8,42 \%$.

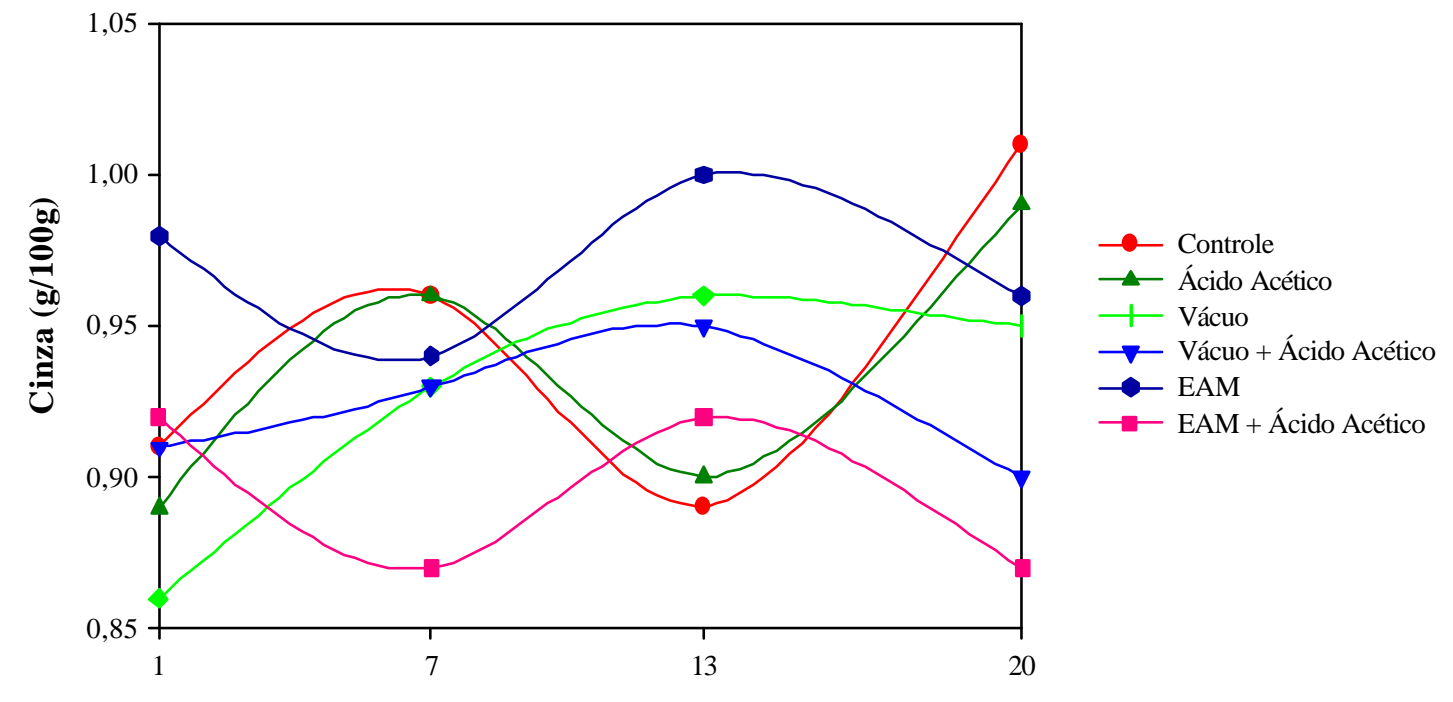

Armazenamento (Dias)

Figura 17 - Cinza em filés de tilápia mantidos sob refrigeração a $1 \pm 1^{\circ} \mathrm{C}$, durante 20 dias.

\subsubsection{Nitrogênio não protéico - NNP}

A Tabela 5 e a Figura 18 apresentam os dados da variação do NNP em filés de tilápia durante o período de armazenamento. Os valores de NNP não foram afetados 
significativamente (Teste F) pelos tratamentos e pelo período de armazenamento. Porém, apresentaram-se com comportamento irregular, ocorrendo variações durante o período de armazenamento. Este fato pode levar a se supor que o NNP não deva ser adequado como índice de avaliação na qualidade da tilápia minimamente processada.

Segundo Sikorski et al. (1994) o NNP é utilizado para determinação do frescor, por ser a primeira fração a ser utilizada pelos microrganismos, servindo de fonte de energia para os mesmos. De acordo com Mujica (2000) uma provável explicação para estas variações seria a ocorrência simultânea da utilização de substâncias resultantes da atividade microbiana sobre aminoácidos sulfurados, principalmente na forma livre como componentes do "pool" de NNP, causando sua redução, e ao mesmo tempo gerando e repondo muitos compostos constituintes, em decorrência de reações autolíticas e atividade proteolítica dos microrganismos.

Tabela 5. Nitrogênio não protéico $(\mathrm{mg} / 100 \mathrm{~g})$ em filés de tilápia mantidos sob refrigeração a $1 \pm 1^{\circ} \mathrm{C}$, durante 20 dias.

\begin{tabular}{ccccccc}
\hline \multirow{2}{*}{\begin{tabular}{c} 
Armazenamento $\begin{array}{c}\text { Tratamentos } \\
\text { (Dias) }\end{array}$ \\
\cline { 2 - 7 }
\end{tabular}} & Controle & $\begin{array}{c}\text { Ácido } \\
\text { Acético }\end{array}$ & Vácuo & $\begin{array}{c}\text { Vácuo + Ác. } \\
\text { Acético }\end{array}$ & EAM & $\begin{array}{c}\text { EAM + Ác. } \\
\text { Acético }\end{array}$ \\
\hline 1 & 534,72 & 642,76 & 590,76 & 581,59 & 635,29 & 614,02 \\
7 & 534,63 & 560,35 & 590,29 & 522,48 & 536,25 & 493,64 \\
13 & 595,96 & 522,17 & 589,81 & 533,01 & 568,21 & 524,86 \\
20 & 568,52 & 538,64 & 525,90 & 517,26 & 511,82 & 470,13 \\
\hline
\end{tabular}

EAM: Embalagem sob atmosfera modificada com $60 \% \mathrm{CO}_{2}+40 \% \mathrm{O}_{2} ; \mathrm{F} /$ Armazenamento= 4,39 n.s.; $\mathrm{F} /$ Tratamento $=0,69$ n.s.; F/Interação $=0,77$ n.s.; C.V. $=28,04 \%$. 


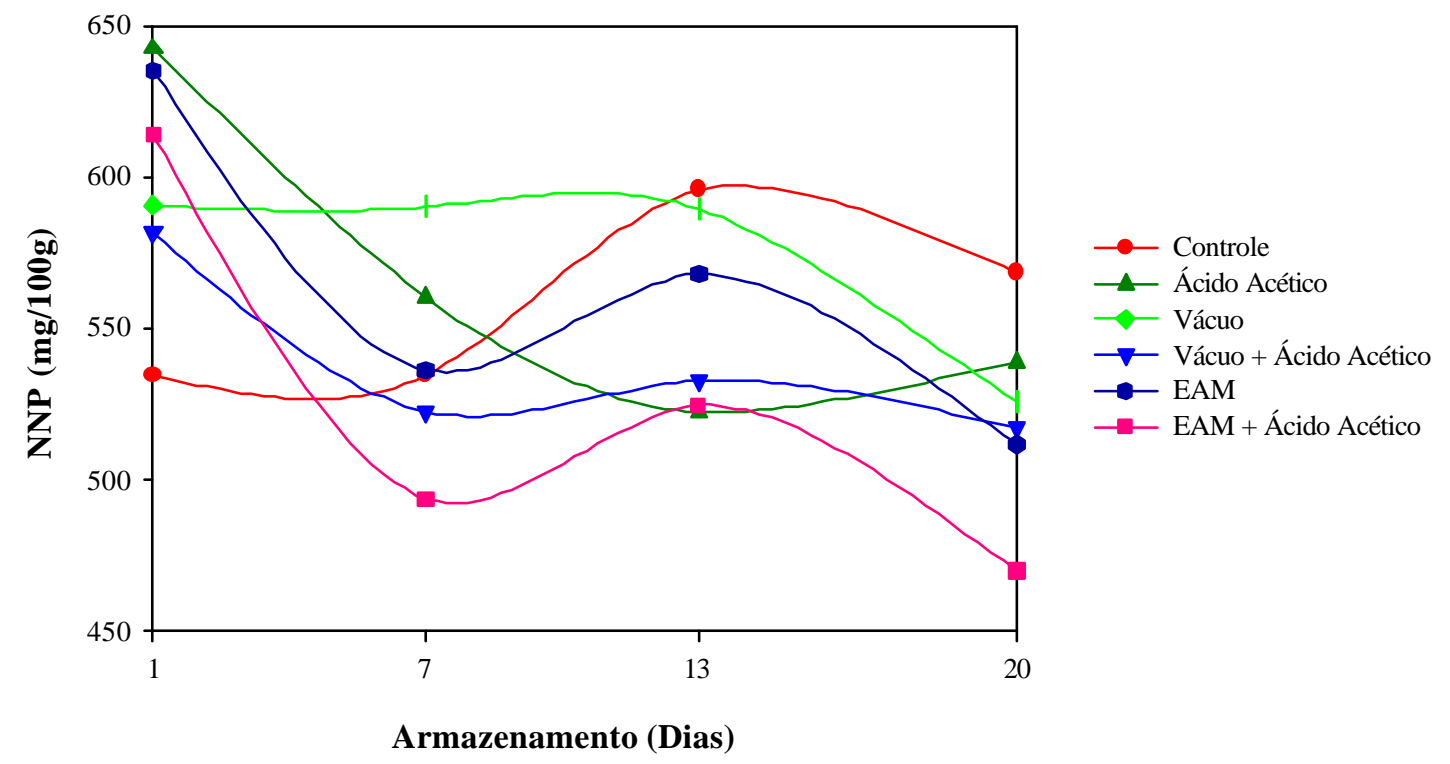

Figura 18 - Nitrogênio não protéico em filés de tilápia mantidos sob refrigeração a $1 \pm 1^{\circ} \mathrm{C}$, durante 20 dias.

Os valores iniciais mais baixos de NNP, observados para o controle, podem ter ocorrido devido ao consumo, durante as primeiras $24 \mathrm{~h}$, de compostos nitrogenados, pela flora bacteriana existente. De acordo com Loaiza (1996) a queda inicial nos teores de NNP indica um consumo inicial dos compostos nitrogenados de baixo peso molecular, pela flora bacteriana existente, antes de se ter início uma proteólise elevada. Apenas quando os compostos nitrogenados existentes não são suficientes para satisfazer as exigências nutricionais, os microrganismos iniciarão a degradação das proteínas.

Moorjani et al. (1962) observaram em um estudo com várias espécies de pescado de água doce, o decréscimo do NNP durante os 16 dias de estocagem sob gelo. Os autores concluem que, se as proteínas fossem hidrolisadas por ação bacteriana e enzimática, o NNP deveria aumentar, significativamente, durante o período de armazenamento. 
Segundo Lahiry et al. (1963) o decréscimo gradual de aminoácidos livres durante a estocagem, se deve em parte à lixiviação, provocada pelo efeito da lavagem do gelo fundido utilizado na estocagem do produto.

De acordo com Netto (1984), a tilápia do Nilo (Oreochromis niloticus) apresentou, inicialmente, $294 \mathrm{mg} \mathrm{N} / 100 \mathrm{~g}$, e após 20 dias de estocagem em gelo, ocorreu uma redução para $208 \mathrm{mg} \mathrm{N} / 100 \mathrm{~g}$. O autor atribui os teores mais altos do NNP, na fase inicial, às atividades das catepsinas; nas fases posteriores, às proteases microbianas.

Em uma pesquisa com cação (Squalus acanthias), Jhaveri \& Constantinides observaram que a concentração inicial de NNP foi de $800 \mathrm{mg} / 100 \mathrm{~g}$, mas depois de quatro dias de armazenamento houve decréscimo para $450 \mathrm{mg} / 100 \mathrm{~g}$; somente depois de 2 semanas foi observado a degradação de uréia em amônia por ação bacteriana.

Em outro estudo Contreras-Guzmán (1994) descreve teores de NNP de 210, 253, 327, 330, 332 e $343 \mathrm{mg} \mathrm{N} / 100 \mathrm{~g}$, para mandi (Pimelodus maculatus), curimbatá (Prochilodus scrofa), pacu (Piaractus mesopatamicus), carpa (Cyprinus carpio), tambaqui (Colossoma macropomum) e tilápia (Oreochromis niloticus), respectivamente, todos no estado de fresco e coletados em diferentes épocas do ano.

Siqueira (2001) encontrou valores de 1000 e $1333,3 \mathrm{mg} / 100 \mathrm{~g}$ de NNP para a tilápia (Oreochromis niloticus) in natura aos 20 e 30 dias de armazenamento, respectivamente, sob refrigeração a $0,5-1^{\circ} \mathrm{C}$.

Os peixes cultivados geralmente apresentam um conteúdo mais baixo de nitrogênio não protéico em relação aos peixes não cultivados. Os peixes que contém mais NNP no músculo podem estar propensos à rápida perda de qualidade, por causa da ação bacteriana e/ou enzimática na decomposição de metabólitos (Jhaveri \& Constantinides, 1982).

\subsubsection{Bases nitrogenadas voláteis totais - BNVT}

Os dados da variação de BNVT em filés de tilápia estão dispostos na Tabela 6 e na Figura 19. Os valores de BNVT não foram afetados, significativamente (Teste F), pelos tratamentos e pelo período de armazenamento. Todos os tratamentos apresentaram 
valores abaixo do estabelecido pela legislação brasileira (30 mg/100g). Observou-se inicialmente, valores mais elevados, para a maioria dos tratamentos, com exceção dos tratamentos a vácuo + ácido acético e EAM + ácido acético; segundo Cobb III et al. (1974) e Yeh et al. (1978) esse aumento inicial da amônia pode ser contrabalançado pela lixiviação, principalmente se a área de exposição for muito grande (filés, postas); porém após alguns dias o aumento intensifica-se e geralmente coincide com o aumento de $\mathrm{pH}$. Quanto mais alcalino for o meio, mais favorece a atividade das desaminases.

Segundo Sikorski et al. (1994) dentro da denominação genérica de BNVT encontram-se substâncias como amônia, trimetilamina, etilamina, monometilamina, putrescina, cadaverina e espermidina. Portanto, o principal componente deste grupo é a amônia, responsável pelas maiores alterações químicas, quando se trata de peixes de água doce.

Tabela 6. Bases nitrogenadas voláteis totais $(\mathrm{mg} / 100 \mathrm{~g})$ em filés de tilápia mantidos sob refrigeração a $1 \pm 1^{\circ} \mathrm{C}$, durante 20 dias.

\begin{tabular}{ccccccc}
\hline \multirow{2}{*}{\begin{tabular}{c} 
Armazenamento $\begin{array}{c}\text { Tratamentos } \\
\text { (Dias) }\end{array}$ \\
\cline { 2 - 7 }
\end{tabular}} & Controle & $\begin{array}{c}\text { Ácido } \\
\text { Acético }\end{array}$ & Vácuo & $\begin{array}{c}\text { Vácuo + Ác. } \\
\text { Acético }\end{array}$ & EAM & $\begin{array}{c}\text { EAM + Ác. } \\
\text { Acético }\end{array}$ \\
\hline 1 & 14,00 & 13,07 & 14,70 & 12,13 & 13,07 & 12,13 \\
7 & 13,30 & 11,20 & 12,60 & 13,07 & 11,90 & 12,13 \\
13 & 14,00 & 12,37 & 15,17 & 14,00 & 13,07 & 13,07 \\
20 & 18,90 & 17,97 & 17,03 & 17,03 & 16,57 & 14,93 \\
\hline
\end{tabular}

EAM: embalagem sob atmosfera modificada com $60 \% \mathrm{CO}_{2}+40 \% \mathrm{O}_{2} ; \mathrm{F} /$ Armazenamento= 6,76 n.s.; F/Tratamento=0,62 n.s.; F/Interação=0,18 n.s.; C.V.=24,07\%. 


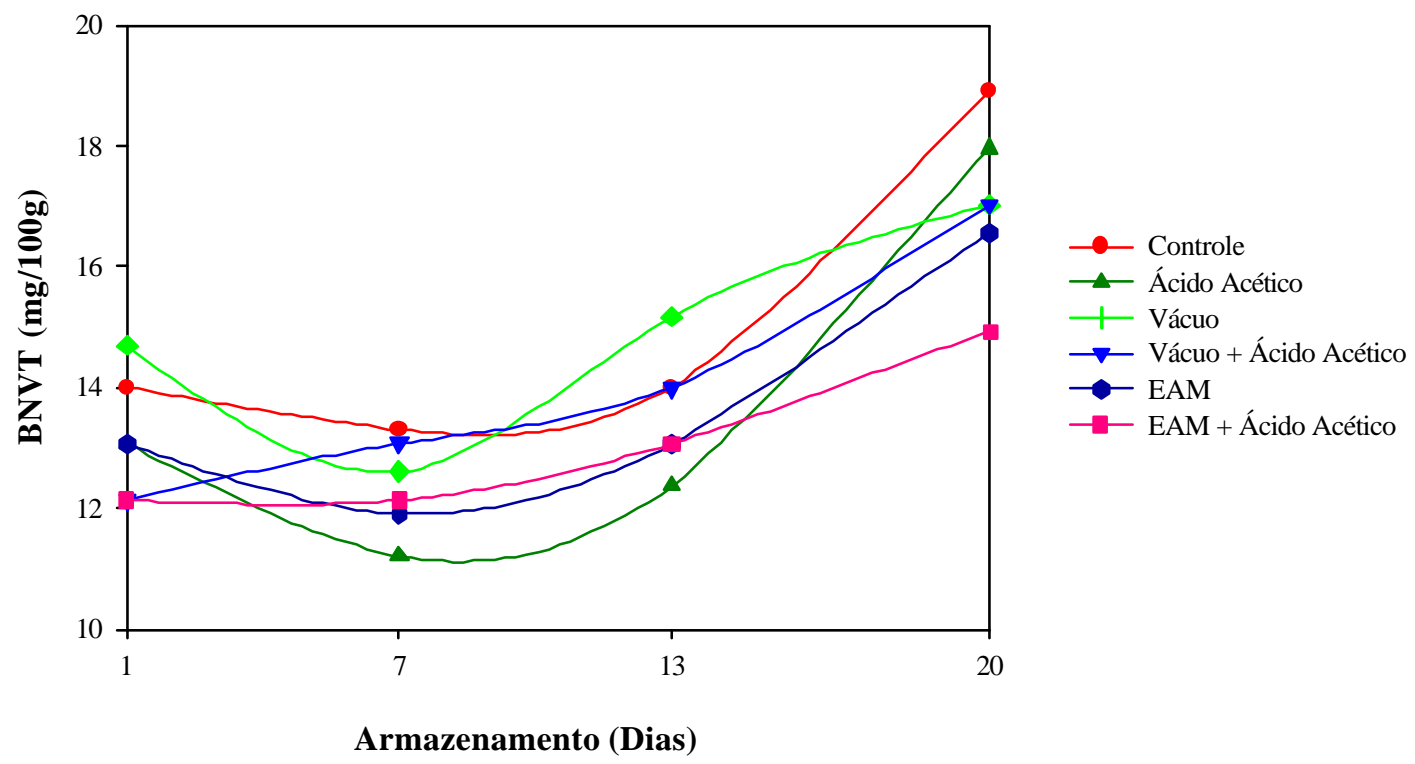

Figura 19 - Bases nitrogenadas voláteis totais em filés de tilápia mantidos sob refrigeração a $1 \pm 1^{\circ} \mathrm{C}$, durante 20 dias.

A determinação de BNVT em pescado, embora seja utilizada na avaliação do frescor, é causa de controvérsia entre pesquisadores, principalmente em relação aos limites de aceitação do produto. O valor de $30 \mathrm{mg} / 100 \mathrm{~g}$ tem-se mostrado compatível com outros parâmetros de avaliação, levando alguns países, dentre eles o Brasil a adotarem este valor como limite máximo para comercialização (BRASIL, 2002b; Kuaye, 1982; Sikorski et al., 1994). No entanto, Kuaye (1982) descreve que os teores de BNVT variam de acordo com a metodologia, a espécie de pescado e o estágio de alteração, sendo pouco sensíveis para pescado de água doce, onde não foram observadas alterações importantes, mesmo após vários dias de estocagem em gelo.

Segundo Ogawa \& Maia (1999), nos peixes em excelente estado de frescor, o teor de BNVT atinge 5 a $10 \mathrm{mg} / 100 \mathrm{~g}$ de músculo, e em peixes com frescor razoável podem atingir de 15 a $25 \mathrm{mg} / 100 \mathrm{~g}$ de músculo.

Os valores encontrados nesta pesquisa foram semelhantes aos encontrados por 
Paludan-Müller et al. (1998) em salmão do Atlântico (Salmo salar) defumado e embalado a vácuo e em EAM contendo $60 \% \mathrm{CO}_{2}+40 \% \mathrm{~N}_{2}$ a $5^{\circ} \mathrm{C}$, apresentando no final de 4 semanas $18 \mathrm{mg} \mathrm{N} / 100 \mathrm{~g}$.

De acordo com Mujica (1988) as tilápias do Nilo (Oreochromis niloticus) evisceradas e mantidas sob gelo apresentaram um comportamento irregular quanto aos teores de BNVT, variando de 15,08 a 21,05 mg/100g de músculo, depois de 3 dias de armazenamento.

Araújo et al. (2000) avaliaram a vida útil da pescadinha (Cynoscion spp) resfriada e comercializada no mercado de Niterói, RJ após 4 dias de exposição à venda, quando os peixes apresentaram 13,06 mg BNVT/100g.

Segundo Manthey et al. (1988) em "catfish" Europeu (Silurus glanis) armazenado sob gelo durante 30 dias, os teores BNVT variaram de 20,1 a 21,9 mg/100g; os autores apontam que este não está sendo um índice adequado para a determinação do estado de frescor.

Debevere \& Voets (1972) relataram que a adição de ácido cítrico nas concentrações de 0,1 a $0,3 \%$ em filés de bacalhau armazenado a $0^{\circ} \mathrm{C}$, inibiu a formação de BNVT durante 6 dias. A adição do ácido promoveu o decréscimo do crescimento bacteriano e a redução do $\mathrm{pH}$. Porém, o aumento de BNVT pode ser atribuído à presença de bactérias que atingiram um determinado nível de contagem, que permite a ocorrência da desaminação de aminoácidos, os quais são convertidos em amônia.

Segundo Banks et al. (1980) há muitas explicações possíveis para as diferenças nos valores de BNVT entre o pescado embalado com ou sem $\mathrm{CO}_{2}$. Primeiro nota-se o efeito inibitório do $\mathrm{CO}_{2}$ sobre a diminuição no número de bactérias, que reflete na contagem total, conseqüientemente, provoca a redução na quantidade de BNVT, estabelecida sobre o mesmo peixe. Assim, as diferenças produzidas em BNVT podem ser somente devidas ao menor número de bactérias presentes e/ou a menor habilidade dessas bactérias para agir na desaminação oxidativa dos componentes do nitrogênio não protéico.

A segunda explicação pode ser devido às condições anaeróbias presentes nas EAM contendo $\mathrm{CO}_{2}$, pois se a maior produção de amônia é devida à desaminação 
oxidativa de compostos nitrogenados não protéicos nos tecidos do pescado, uma condição anaeróbia poderá inibir essas reações, devido à falta de oxigênio atmosférico (Liston et al., 1963). O tipo de bactéria presente pode estar na dependência das alterações das condições atmosféricas e de $\mathrm{pH}$, causadas pela absorção de $\mathrm{CO}_{2}$. Estas bactérias têm habilidade restringida para produção de amônia, quando comparadas às bactérias deterioradoras mais tradicionais. Portanto, o mecanismo de deterioração do pescado embalado em EAM com $\mathrm{CO}_{2}$ é diferente daquele existente no pescado mantido sob gelo, e a produção de BNVT não é um bom indicador de deterioração.

\subsubsection{Reações do ácido tiobarbitúrico -TBARS}

A Tabela 7 e a Figura 20 apresentam os dados da variação de TBA em filés de tilápia durante o período de armazenamento. Os valores de TBA foram afetados significativamente $(\mathrm{p}<0,05)$ pelos tratamentos e pelo período de armazenamento. Os tratamentos EAM e a EAM + ácido acético foram os que apresentaram os valores mais elevados de TBA (1,36 mg MA/kg), sendo a rancidez percebida sensorialmente pelos provadores, a partir do $7^{\underline{0}}$ dia de armazenamento. Os valores mais elevados de TBA encontrados nestes tratamentos, provavelmente ocorreram devido à oxidação dos ácidos graxos polinsaturados, propiciadas pelas de altas concentrações de $\mathrm{O}_{2}$ nestas embalagens.

Tabela 7. Ácido tiobarbitúrico (mg MA/kg) em filés de tilápia mantidos sob refrigeração a $1 \pm 1^{\circ} \mathrm{C}$, durante 20 dias.

\begin{tabular}{ccccccc}
\hline \multirow{2}{*}{\begin{tabular}{c} 
Armazenamento $\begin{array}{c}\text { Tratamentos } \\
\text { (Dias) }\end{array}$ \\
\cline { 2 - 7 }
\end{tabular}} & Controle & $\begin{array}{c}\text { Ácido } \\
\text { Acético }\end{array}$ & Vácuo & $\begin{array}{c}\text { Vácuo + Ác. } \\
\text { Acético }\end{array}$ & EAM & $\begin{array}{c}\text { EAM + Ác. } \\
\text { Acético }\end{array}$ \\
\hline 1 & $0,04 \mathrm{Aa}$ & $0,84 \mathrm{Aa}$ & $0,00 \mathrm{Aa}$ & $0,71 \mathrm{Aa}$ & $0,57 \mathrm{Aa}$ & $0,79 \mathrm{Aa}$ \\
7 & $0,78 \mathrm{Aa}$ & $1,58 \mathrm{Aa}$ & $0,17 \mathrm{Aa}$ & $0,73 \mathrm{Aa}$ & $1,36 \mathrm{Aa}$ & $3,00 \mathrm{Aab}$ \\
13 & $0,79 \mathrm{Aa}$ & $2,38 \mathrm{Aa}$ & $0,48 \mathrm{Aa}$ & $0,93 \mathrm{Aa}$ & $2,22 \mathrm{Aa}$ & $6,16 \mathrm{Bbc}$ \\
20 & $0,98 \mathrm{Aa}$ & $2,56 \mathrm{Aa}$ & $0,57 \mathrm{Aa}$ & $1,29 \mathrm{Aa}$ & $8,07 \mathrm{Bb}$ & $9,23 \mathrm{Bc}$ \\
\hline
\end{tabular}

EAM: Embalagem sob amosfera modificada com $60 \% \mathrm{CO}_{2}+40 \% \mathrm{O}_{2}$; Médias seguidas pela mesma letra, minúscula nas colunas e maiúscula nas linhas, não diferem pelo teste de Tukey a 5\%; F/Armazenamento= $19,11^{*} ; \mathrm{F} /$ Tratamento $=19,12^{*} ; \mathrm{F} /$ Interação $=4,63^{*} ;$ C.V. $=70,74 \%$. 


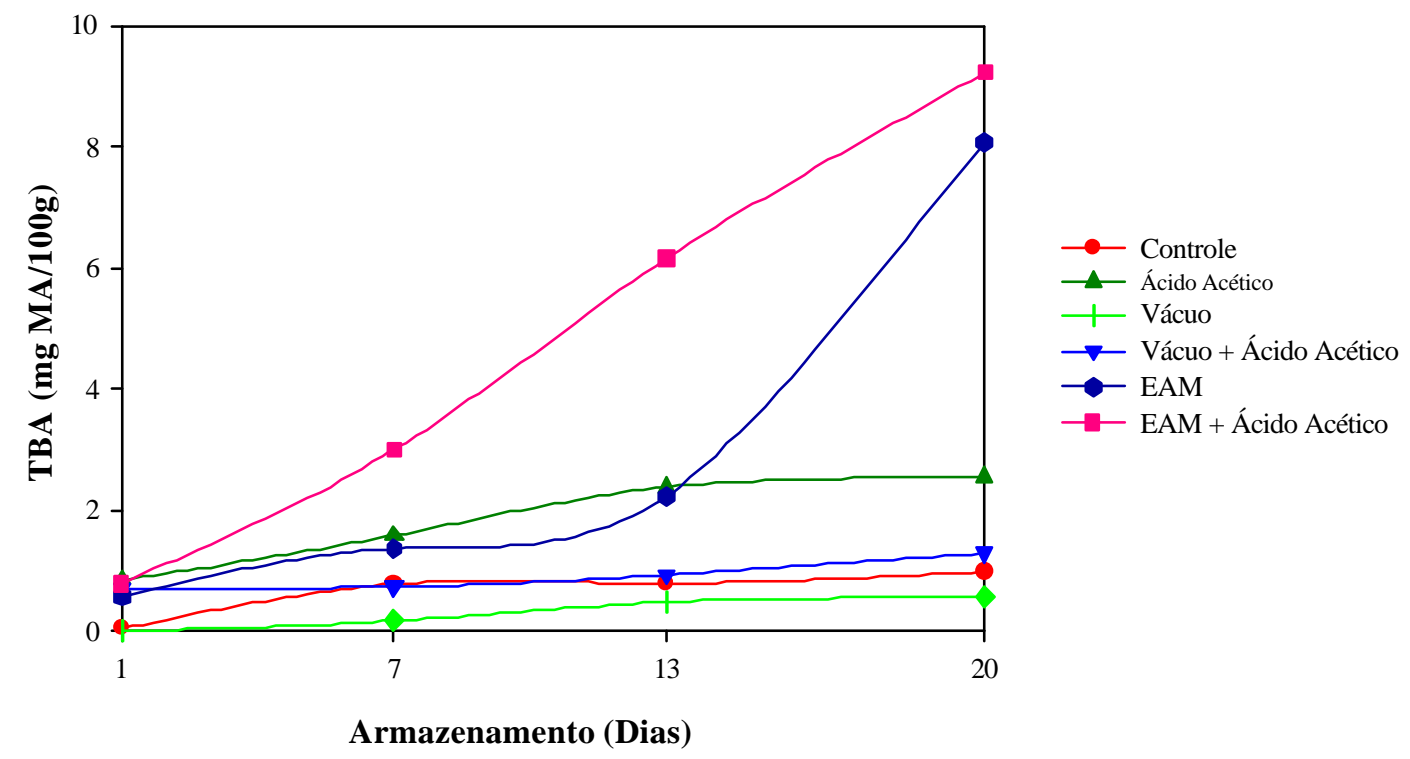

Figura 20 - Ácido tiobarbitúrico em filés de tilápia mantidos sob refrigeração a $1 \pm 1^{\circ} \mathrm{C}$, durante 20 dias.

No tratamento a vácuo, os valores observados para TBA foram os mais baixos (0,57 mg MA/100g), no final do período de armazenamento, quando comparado com os demais tratamentos, provavelmente isso tenha ocorrido devido à baixa concentração de $\mathrm{O}_{2}$ presente neste tratamento, que retardou o processo oxidativo dos ácidos graxos polinsaturados.

O produto pode ser considerado em bom estado, quando os teores de TBA estão abaixo de 3,0 mg MA/kg. A legislação brasileira não apresenta limite máximo de malonaldeído/kg em produtos cárneos (Al-Kahtani et al., 1996).

Ke et al. (1984) trabalhando com várias espécies de pescado, sugerem valores inferiores a 0,576 mg MA/kg, como baixos, ou indicadores de nenhuma rancidez; entre 0,648 e 1,44 mg MA/kg, como levemente rançosos, e valores superiores a 1,51, como rançosos e inaceitáveis.

A oxidação consiste em uma série de reações em cadeia, resultando em inúmeros 
compostos tais como, álcoois, cetonas, hidrocarbonetos, entre outros, os quais conferem sabor e odor de ranço, bem como promovem a modificação da cor, quando há transformação do pigmento oximioglobina (vermelho brilhante) em metamioglobina (marrom-acinzentado). A textura da carne também pode ser alterada, resultando na formação de complexos, lipídeo-protéicos ou provocar a cisão das proteínas (Khayat \& Schwall, 1983; Kanner, 1994). O processo oxidativo inicia-se logo após a morte do pescado, podendo ser favorecido pela exposição ao ar atmosférico, temperatura elevada, desidratação e a presença de agentes pró-oxidantes (Machado, 1994).

Segundo Bak et al. (1999) é muito forte a correlação entre o enrijecimento da carne e a oxidação lipídica, indicando que o principal caminho do enrijecimento da carne é a interação das proteínas com os produtos da oxidação lipídica.

Há dois tipos de rancidez, hidrolítica e oxidativa. No caso da rancidez hidrolítica, o odor é causado pela presença de ácidos graxos livres, microrganismos e água. A rancidez oxidativa é um problema mais comum, ocorre devido à oxidação de ácidos graxos polinsaturados, podendo ser um problema em atmosferas modificadas contendo $\mathrm{O}_{2}$. $\mathrm{O} \mathrm{O}_{2}$ age nos ácidos graxos, gerando os hidroperóxidos, que vão degradando os componentes do odor (Church, 1998).

Kosak \& Toledo (1981) observaram que tainhas (Mugil cephalus) armazenadas por 12 dias a $-2^{\circ} \mathrm{C}$, em embalagem de polietileno e a vácuo, apresentaram um valor máximo de TBA de 7,5mg MA/kg, para ambas as embalagens.

Em postas de salmão do Atlântico (Salmo salar) mantidas a $2 \pm 1^{\circ} \mathrm{C}$ em $100 \%$ de $\mathrm{CO}_{2}$, os valores de TBA foram aumentados com o período de armazenamento, mas a rancidez oxidativa foi observada somente depois de 20 dias, quando o valor de TBA atingiu 12mg MA/kg (Pastoriza et al., 1996b).

Segundo Brown et al. (1980); Barnett et al. (1982); Lannelongue et al. (1982) e Przylbylski et al. (1989) o $\mathrm{CO}_{2}$ não parece prevenir a rancidez, no entanto, em contraparte atmosferas com $\mathrm{O}_{2}$ não necessariamente são promotores de rancidez (Wang \& Brown, 1983).

Ruiz-Capillas \& Moral (2001) encontraram valores de TBA de 0,97 mg MA/100g em atmosferas com 40\% de $\mathrm{CO}_{2}$, e de 2,2 mg MA/100g em atmosferas com 
$60 \%$ de $\mathrm{CO}_{2}$, em merluza (Merluccius merluccius) eviscerada e inteira submetida ao armazenamento a $0 \pm 1{ }^{\circ} \mathrm{C}$ durante 25 dias. Os autores relataram que este aumento nos teores de TBA é decorrente de provável ação sinergística do $\mathrm{CO}_{2}$ e $\mathrm{O}_{2}$, na autoxidação dos polinsaturados.

\subsection{5 pH}

A Tabela 8 e a Figura 21 apresentam os valores obtidos para o pH em filés de tilápia durante o período de armazenamento. Os valores de $\mathrm{pH}$ não foram afetados significativamente $(p>0,05)$ pelos tratamentos, apresentando-se mais estáveis, com pequenas variações. Porém, os mesmos foram afetados significativamente $(\mathrm{p}<0,05)$ pelo período de armazenamento. Apenas o controle apresentou valores de $\mathrm{pH}$ acima do permitido pela legislação brasileira, a partir $13^{0}$ dia de armazenamento, e permanecendo estável até o término do experimento. $\mathrm{O}$ aumento nos valores de $\mathrm{pH}$ está relacionado com o aumento de psicrotróficos, que atingiu níveis superiores a $10^{6} \mathrm{UFC} / \mathrm{g}$ para o controle, aos 20 dias de armazenamento, evidenciando desse modo, as atividades proteolítica e lipolítica.

Tabela 8. Valores de $\mathrm{pH}$ em filés de tilápia mantidos sob refrigeração a $1 \pm 1^{\circ} \mathrm{C}$, durante 20 dias.

\begin{tabular}{ccccccc}
\hline \multirow{2}{*}{$\begin{array}{c}\text { Armazenamento } \\
\text { (Dias) }\end{array}$} & Controle & $\begin{array}{c}\text { Ácido } \\
\text { Acético }\end{array}$ & Vácuo & $\begin{array}{c}\text { Vácuo + Ác. } \\
\text { Acético }\end{array}$ & EAM & $\begin{array}{c}\text { EAM + Ác. } \\
\text { Acético }\end{array}$ \\
\cline { 2 - 7 } & $6,5 \mathrm{Aa}$ & $6,2 \mathrm{Aa}$ & $6,4 \mathrm{Aa}$ & $6,1 \mathrm{Ba}$ & $6,4 \mathrm{Aa}$ & $5,9 \mathrm{Ba}$ \\
7 & $6,4 \mathrm{Aa}$ & $6,1 \mathrm{Aa}$ & $6,4 \mathrm{Aa}$ & $6,0 \mathrm{Ba}$ & $6,4 \mathrm{Aa}$ & $6,2 \mathrm{Aa}$ \\
13 & $6,6 \mathrm{Aa}$ & $6,2 \mathrm{Ba}$ & $6,5 \mathrm{Aa}$ & $6,2 \mathrm{Ba}$ & $6,5 \mathrm{Aa}$ & $6,1 \mathrm{Ba}$ \\
20 & $6,6 \mathrm{Aa}$ & $6,3 \mathrm{Aa}$ & $6,5 \mathrm{Aa}$ & $6,2 \mathrm{Ba}$ & $6,5 \mathrm{Aa}$ & $6,2 \mathrm{Ba}$ \\
\hline
\end{tabular}

EAM: Embalagem sob amosfera modificada com $60 \% \mathrm{CO}_{2}+40 \% \mathrm{O}_{2}$; Médias seguidas pela mesma letra, minúscula nas colunas e maiúscula nas linhas, não diferem pelo teste de Tukey a 5\%; F/Armazenamento= 4,53*; F/Tratamento= 16,53 n.s.; F/Interação=0,45 n.s.; C.V.=2,44\%. 


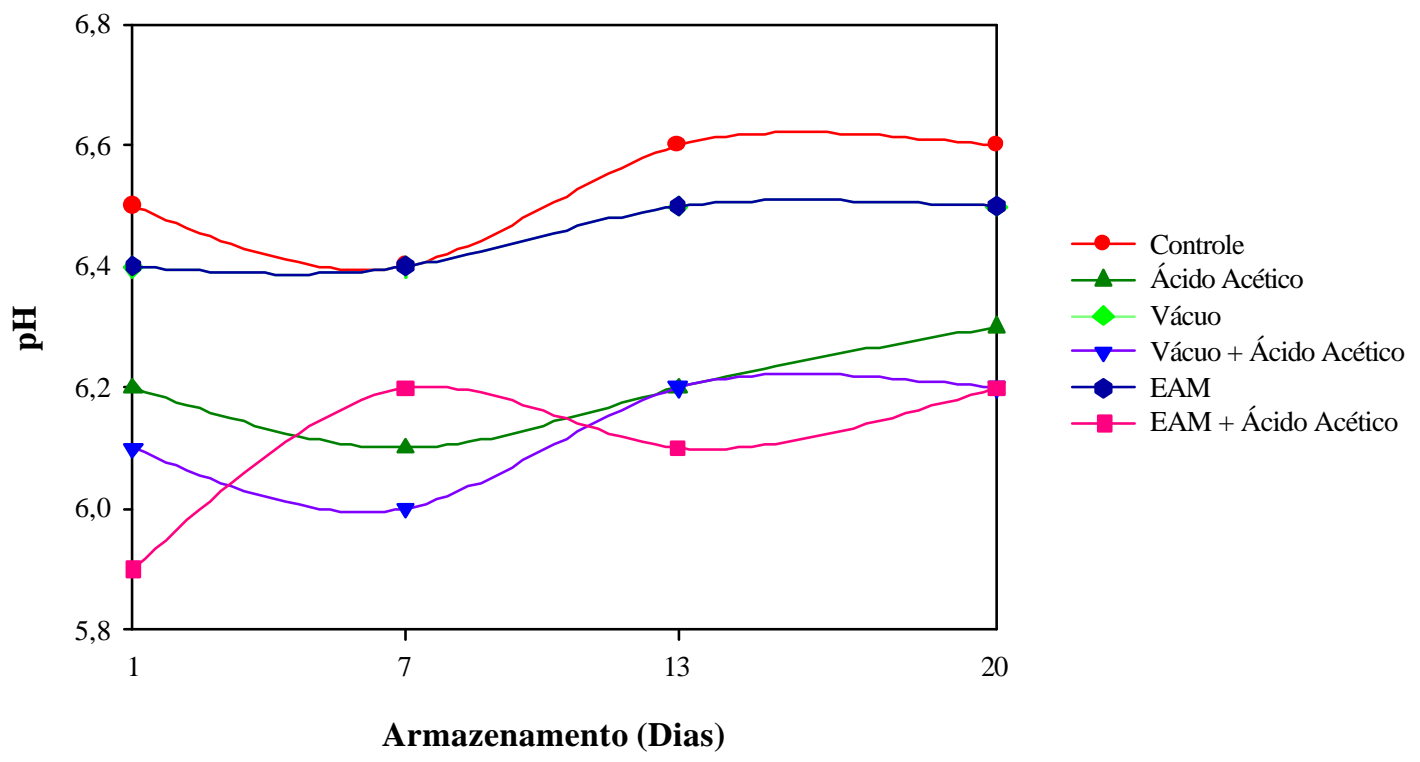

Figura 21 - Valores de $\mathrm{pH}$ em filés de tilápia mantidos sob refrigeração a $1 \pm 1^{\circ} \mathrm{C}$, durante 20 dias.

$\mathrm{O}$ aumento de $\mathrm{pH}$ no músculo do pescado pode ser devido ao acúmulo de produtos de natureza básica, como trimetilamina (TMA), demitilamina (DMA), amônia, indol, escatol e algumas bases orgânicas, como putrescina e cadaverina, produzidas pela hidrólise bacteriana de compostos nitrogenados (Pedrosa-Menabrito \& Regenstein, 1988; Sikorski et al., 1994).

O Regulamento da Inspeção Industrial e Sanitária de Produtos de Origem Animal - RIISPOA (BRASIL, 2002b) estabelece limites máximos de pH de 6,5 para parte interna do pescado fresco. Com base nos resultados obtidos, esse critério parece ser adequado para avaliação de qualidade da tilápia minimamente processada.

Segundo Sikorski et al. (1994) a estabilidade do $\mathrm{pH}$ se deve ao efeito tamponante do músculo do pescado. Esse efeito é atribuído à presença de proteínas solúveis, peptídeos, aminoácidos, amônia, trimetilamina e substâncias solúveis, de baixo peso molecular que podem mascarar as mudanças de $\mathrm{pH}$, fazendo com que os valores de $\mathrm{pH}$ do músculo do pescado aumentem de forma lenta no início, e rapidamente no processo da deterioração. 
De acordo com Debevere \& Boskou (1996) a difusão do $\mathrm{CO}_{2}$ sobre o músculo do pescado apresenta um efeito contrário sobre o incremento do $\mathrm{pH}$, pela produção de BNVT, resultando na estabilização do $\mathrm{pH}$.

Mudanças de $\mathrm{pH}$ não foram dectetadas em várias espécies de pescado de água doce, (Barbus carnaticus, Barbus dubious, Labeo, Ophicephalus e Wallago attu) estocados sob gelo durante 12 dias (Lahiry et al., 1963).

Dalgaard et al. (1993) observaram que, embora tenha ocorrido aumento do nível de $\mathrm{CO}_{2}(97 \%)$ em filés de bacalhau (Gadus morhua) mantidos a $0^{\circ} \mathrm{C}$, durante o período de 20 dias, o pH permaneceu constante entre 6,5 a 6,6.

O decréscimo de $\mathrm{pH}$ observado para os tratamentos a vácuo + ácido acético $(6,1-6,0)$ e $\mathrm{EAM}+$ ácido acético $(6,2-6,1)$, no $7^{\underline{0}}$ e $13^{\underline{o}}$ dias de armazenamento, respectivamente, está relacionado com o decréscimo na contagem de psicrotróficos, como consequiência da ação bacteriostática do ácido acético e do $\mathrm{CO}_{2}$, no músculo do pescado.

Segundo Parkin et al. (1981) e Scott et al. (1986) o decréscimo inicial do pH superficial em filés de "rockfish" (Sebastes spp) embalados em EAM pode ser atribuído à dissolução do $\mathrm{CO}_{2}$ no músculo do pescado, principalmente na forma de bicarbornato e íons de hidrogênio, quando o músculo do pescado apresenta o pH $\quad 6,0$.

Wang \& Brown (1983) relataram o decréscimo de $\mathrm{pH}(7,9-7,3)$ durante o período de armazenamento (28 dias) em carne de lagosta (Pacifastacus leniusculus), mantida sob atmosfera contendo $80 \%$ de $\mathrm{CO}_{2}$ a $4^{\circ} \mathrm{C}$.

Reddy et al. (1994) também observaram o decréscimo de pH (6,2-6,0) em filés de tilápia (Tilapia spp) embalados em EAM com $75 \% \mathrm{CO}_{2}+25 \% \mathrm{~N}_{2}$, depois de 30 dias de armazenamento sob refrigeração a $4{ }^{\circ} \mathrm{C}$.

$\mathrm{O}$ decréscimo do $\mathrm{pH}$ em sistemas com EAM tem sido atribuído à formação de ácido lático pelos Lactobacillus, que pode inibir o crescimento de bactérias deteriorativas causadoras de odores, e à formação de ácido carbônico, quando as condições forem anaeróbias (Gray et al., 1983).

De acordo com Loaiza (1996) a queda de pH no músculo do pescado pode ser devido ao desenvolvimento de bactérias láticas e a presença de ácidos graxos livres 
(produtos da lipólise), provocada por microrganismos psicrotróficos.

Lannelongue et al. (1982) observaram o decréscimo inicial de pH $(6,8-6,7)$ em camarão (Penaeus aztecus) armazenado em EAM com $65 \%$ de $\mathrm{CO}_{2}$ a $4^{\circ} \mathrm{C}$, porém não houve inibição da atividade bacteriana.

Segundo Bremner \& Statham (1983), em experimento com moluscos (Pecten alba) embalados a vácuo, com adição de sorbato de potássio, o $\mathrm{pH}$ do músculo apresentou-se mais elevado no início do experimento, depois decresceu, aumentou novamente e assim, sucessivamente, até o término do experimento.

De acordo com Miller \& Brown (1984) o pH não pode ser usado como índice seguro de estado de frescor, ou de início de deterioração do pescado. Porém, a mudança de $\mathrm{pH}$ reflete a atividade bacteriana.

\subsubsection{Aminoácidos}

A Tabela 9 apresenta os valores obtidos para aminoácidos em filés de tilápia, no ínício e no final do período de armazenamento, para os tratamentos controle, vácuo e EAM. Os valores de aminoácidos decresceram durante o período de armazenamento, sendo que o controle apresentou maior redução em relação à embalagem a vácuo e a EAM, exceto para o ácido glutâmico, a glicina e a lisina. Porém, os tratamentos embalados a vácuo e em EAM mantiveram valores mais elevados, quando comparados ao controle, até o término do período de armazenamento.

Siqueira (2001) também observou diminuição dos teores aminoácidos em tilápia do Nilo irradiada (Oreochromis niloticus), utilizando a dose de $5 \mathrm{kGy}$. Porém, as amostras irradiadas com $1 \mathrm{kGy}$ mantiveram-se mais estáveis durante o período de armazenamento de 30 dias.

A composição em aminoácidos do pescado pode variar em função da metodologia, uma vez que a hidrólise geralmente é ineficiente e o cálculo dos teores de aminoácidos é prejudicado pelo nitrogênio não protéico presente na amostra (Geiger, 1962).

Segundo Ogawa \& Maia (1999) as perdas de aminoácidos podem ser oriundas de alterações bioquímicas ou devido à atividade bacteriana, que promove a 
descarboxilação, na qual as enzimas reagem com aminoácidos do grupo $\mathrm{COOH}$ terminal, formando aminas reativas e $\mathrm{CO}_{2}$. Quando ocorrem rompimentos entre as ligações carbônicas, são provocadas alterações irreversíveis nas várias funções da proteína, resultando em alterações na atividade biológica, solubilidade, capacidade de reação com grupos constituintes (resíduos de aminoácidos), alterações no tamanho e na formação de moléculas, ou seja, a desnaturação protéica.

Tabela 9. Aminoácidos totais ( $\mathrm{g} / 100 \mathrm{~g}$ em matéria seca) em filés de tilápia mantidos sob refrigeração a $1 \pm 1{ }^{\circ} \mathrm{C}$, durante 20 dias.

\begin{tabular}{lcccccc}
\hline \multirow{2}{*}{ Aminoácidos } & \multicolumn{7}{c}{ Tratamentos } \\
\cline { 2 - 7 } & $\begin{array}{c}\text { Controle } \\
(1 \text { dia })\end{array}$ & $\begin{array}{c}\text { Controle } \\
(20 \text { dias })\end{array}$ & $\begin{array}{c}\text { Vácuo } \\
(1 \text { dia })\end{array}$ & $\begin{array}{c}\text { Vácuo } \\
(20 \text { dias })\end{array}$ & $\begin{array}{c}\text { EAM } \\
(1)\end{array}$ & $\begin{array}{c}\text { EAM } \\
(20 \text { dias })\end{array}$ \\
\hline Ácido aspártico & 8,43 & 7,67 & 8,74 & 8,28 & 9,48 & 9,24 \\
Tirosina & 2,71 & 2,08 & 2,41 & 2,29 & 2,99 & 2,94 \\
Serina & 3,18 & 2,93 & 3,45 & 3,24 & 3,62 & 3,57 \\
Ácido glutâmico & 12,67 & 12,01 & 13,68 & 12,82 & 14,24 & 14,23 \\
Prolina & 3,29 & 2,52 & 2,81 & 2,62 & 3,50 & 3,46 \\
Glicina & 4,63 & 4,40 & 4,86 & 4,78 & 5,22 & 4,76 \\
Alanina & 5,10 & 4,66 & 5,35 & 5,15 & 5,77 & 5,49 \\
Cistina & 0,70 & 0,63 & 0,72 & 0,72 & 0,77 & 0,72 \\
Valina & 3,91 & 3,28 & 3,77 & 3,60 & 4,31 & 4,15 \\
Metionina & 2,30 & 2,11 & 2,55 & 2,39 & 2,56 & 2,59 \\
Isoleucina & 3,61 & 3,07 & 3,63 & 3,51 & 3,98 & 3,85 \\
Leucina & 6,46 & 5,48 & 6,27 & 5,89 & 7,27 & 7,00 \\
Treonina & 3,73 & 3,11 & 3,52 & 3,36 & 4,17 & 4,14 \\
Fenilalanina & 3,36 & 2,63 & 3,07 & 2,88 & 3,80 & 3,55 \\
Lisina & 7,48 & 6,46 & 7,38 & 7,06 & 8,48 & 7,38 \\
Histidina & 2,16 & 1,73 & 2,00 & 1,91 & 2,40 & 2,22 \\
Arginina & 5,09 & 4,65 & 5,23 & 4,85 & 5,79 & 5,52 \\
NH3 & 0,82 & 0,92 & 1,03 & 0,96 & 1,05 & 0,91 \\
\hline
\end{tabular}

EAM: Embalagem sob atmosfera modificada com $60 \% \mathrm{CO}_{2}+40 \% \mathrm{O}_{2}$.

As proteínas podem ser atacadas pelos radicais livres intermediários da oxidação de lipídeos, formando as proteínas de radicais livres, as quais podem reagir com outros radicais livres provenientes de lipídeo ou proteína, formando os agregados lipídeo- 
protéicos ou protéicos (Karel et al., 1975). Produtos secundários da oxidação lipídica podem reagir covalentemente com grupos proteícos funcionais e específicos, como cisteína, lisina, ácido aspártico, tirosina, metionina e arginina, aumentando a proteína hidrofóbica (Takama, 1974; Kuusi et al., 1975).

Nos tratamentos analisados, foi detectada a amônia (Tabela 9), tanto no início quanto no término do experimento. Segundo Contreras-Guzmán (1994) a formação de amônia é originária da degradação de nucleotídeos é produzida logo após a captura, eem alguns casos no esforço anterior à captura do pescado. Nas fases subseqüientes, o aumento da amônia vem da degradação de aminoácidos. Abaixo de $20^{\circ} \mathrm{C} \mathrm{e} \mathrm{pH}$ ácido, predomina a descarboxilação, onde a presença de bactérias descarboxilase e é muito freqüente na pele e no trato digestivo. As descarboxilases da ornitina e da lisina são enzimas comuns a várias bactérias, que apresentam as mono e diaminooxidases necessárias para a produção de amônia (Taylor \& Sumner, 1987). Nos produtos embalados a vácuo, a produção de amônia é sustentada em uma primeira fase. Porém, após um período prolongado de armazenamento, a produção de amônia pode-se tornar vigorosa, pela preseça de microrganismos anaeróbios, desaminando os aminoácidos livres formados por outros microrganismos (Contreras-Guzmán, 1994).

Maia \& Ogawa (2000) determinaram a composição de aminoácidos de tambaqui (Colossoma macropomum), pacu (Piaractus mesopatamicus), tilápia do Nilo (Oreochromis niloticus) e curimbatá (Prochilodus scrofa). Os teores de aminoácidos foram semelhantes para as quatro espécies; o ácido glutâmico variou de 19 a 22g/16g N; o ácido aspártico de 11 a 14g/16g N; lisina, 10 a 13g/16g N; leucina, 9 a $12 \mathrm{~g} / 16 \mathrm{~g} \mathrm{~N}$; arginina, 7 a 9g/16g $\mathrm{N}$ e alanina, 7 a $8 \mathrm{~g} / 16 \mathrm{~g}$ N. Os aminoácidos sulfurados (metionina e cisteína) são limitantes no músculo de tilápia e curimbatá.

\subsection{7 Ácidos graxos}

Os valores de ácidos graxos em filés de tilápia, para os tratamentos controle, vácuo e EAM, no início e no final do período de armazenamento estão apresentados na Tabela 10. Durante o período de armazenamento, a proporção de ácidos graxos saturados decresceu em todos os tratamentos; já os monoinsaturados permaneceram 
estáveis, exceto o tratamento em EAM, onde apresentou um ligeiro aumento; os polinsaturados aumentaram, com exceção da EAM, que permaneceu estável.

Tabela 10. Ácidos graxos (g/100g em matéria seca) em filés de tilápia mantidos sob refrigeração a $1 \pm 1^{\circ} \mathrm{C}$, durante 20 dias.

\begin{tabular}{|c|c|c|c|c|c|c|}
\hline \multirow[b]{2}{*}{ Ácidos graxos } & \multicolumn{6}{|c|}{ Tratamentos } \\
\hline & $\begin{array}{l}\text { Controle } \\
\text { (1 dia) }\end{array}$ & $\begin{array}{l}\text { Controle } \\
(20 \text { dias })\end{array}$ & $\begin{array}{l}\text { Vácuo } \\
(1 \text { dia }) \\
\end{array}$ & $\begin{array}{c}\text { Vácuo } \\
\text { (20 dias) }\end{array}$ & $\begin{array}{c}\text { EAM } \\
(1 \text { dia }) \\
\end{array}$ & $\begin{array}{c}\text { EAM } \\
(20 \text { dias })\end{array}$ \\
\hline \multicolumn{7}{|l|}{ Saturados } \\
\hline $\mathrm{C} 14: 0$ & 3,15 & 2,70 & 2,88 & 2,79 & 3,51 & 2,52 \\
\hline C15:0 & 0,27 & 0,36 & 0,36 & 0,36 & 0,45 & 0,36 \\
\hline C16:0 & 23,04 & 21,33 & 23,40 & 22,59 & 23,49 & 21,42 \\
\hline $\mathrm{C} 17: 0$ & 0,18 & 0,18 & 0,27 & 0,27 & 0,27 & 0,27 \\
\hline C18:0 & 5,67 & 5,58 & 5,67 & 5,31 & 5,04 & 5,40 \\
\hline C20:0 & 0,27 & 0,27 & 0,27 & 0,63 & 0,27 & 0,27 \\
\hline C21:0 & 0,09 & 0,18 & 0,09 & 0,27 & 0,18 & 0,09 \\
\hline $\mathrm{C} 22: 0$ & 0,63 & 0,54 & 0,54 & 0,63 & 0,45 & 0,72 \\
\hline $\mathrm{C} 24: 0$ & 0,54 & 0,45 & 0,45 & 0,45 & 0,45 & 0,54 \\
\hline Total & 34,47 & 32,31 & 34,47 & 33,39 & 34,74 & 32,13 \\
\hline \multicolumn{7}{|l|}{ Monoinsaturados } \\
\hline $\mathrm{C} 16: 1 \omega 7$ & 5,04 & 4,77 & 5,04 & 5,40 & 5,49 & 4,86 \\
\hline $\mathrm{C} 18: 1 \omega 9_{\mathrm{T}}$ & 0,36 & 0,45 & 0,36 & 0,36 & 0,36 & 0,36 \\
\hline C18:1 19 & 31,41 & 31,95 & 30,69 & 30,69 & 28,35 & 31,23 \\
\hline $\mathrm{C} 20: 1 \omega 11$ & 1,80 & 1,62 & 1,62 & 1,44 & 1,44 & 1,71 \\
\hline Total & 38,25 & 38,34 & 37,35 & 37,53 & 35,28 & 37,80 \\
\hline \multicolumn{7}{|l|}{ Polinsaturados } \\
\hline $\mathrm{C} 18: 2 \omega 6_{\mathrm{T}}$ & 0,27 & 0,27 & 0,18 & 0,27 & 0,27 & 0,18 \\
\hline $\mathrm{C} 18: 2 \omega 6$ & 12,06 & 13,14 & 12,96 & 13,23 & 13,95 & 13,95 \\
\hline $\mathrm{C} 18: 2 \omega 6 \gamma$ & 0,63 & 0,81 & 0,54 & 0,63 & 0,72 & 0,72 \\
\hline $\mathrm{C} 18: 3 \omega 3 \alpha$ & 0,72 & 0,99 & 0,90 & 0,99 & 0,99 & 0,99 \\
\hline 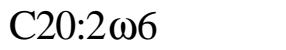 & 0,72 & 0,63 & 0,63 & 0,63 & 0,63 & 0,72 \\
\hline $\mathrm{C} 20: 4 \omega 6$ & 0,72 & 0,81 & 0,63 & 0,81 & 0,72 & 0,72 \\
\hline $\mathrm{C} 20: 5 \omega 3$ & 0,18 & 0,36 & 0,27 & 0,27 & 0,27 & 0,36 \\
\hline $\mathrm{C} 22: 5 \omega 6$ & 0,63 & 0,63 & 0,54 & 0,54 & 0,63 & 0,63 \\
\hline $\mathrm{C} 22: 5 \omega 3$ & 0,27 & 0,36 & 0,27 & 0,36 & 0,45 & 0,36 \\
\hline $\mathrm{C} 22: 6 \omega 3$ & 0,81 & 0,99 & 0,81 & 0,99 & 0,99 & 0,99 \\
\hline Total & 16,74 & 18,72 & 17,55 & 18,45 & 19,35 & 19,44 \\
\hline Não identificado & 0,54 & 0,63 & 0,63 & 0,63 & 0,63 & 0,63 \\
\hline
\end{tabular}

EAM: Embalagem sob atmosfera modificada com $60 \% \mathrm{CO}_{2}+40 \% \mathrm{O}_{2}$. 
Os resultados encontrados foram semelhantes aos encontrados por Andrade et al. (1995; 1997), que avaliaram os níveis de ácidos graxos de 17 espécies de pescado de água doce, na região sul do Brasil, dentre elas, a tilápia (Oreochromis niloticus). Os valores encontrados para a tilápia foram os seguintes: 37,89 a 39,25 g/100g para ácidos graxos saturados; 40,43 a 45,62 g/100g para monoinsaturados e 16,18 a 17,17 g/100g para polinsaturados.

A composição de lipídeos em bacalhau (Gadus morhua) submetidos à privação alimentar (2 meses) e sua relação com os componentes do flavour, resultante da oxidação dos ácidos graxos insaturados, foi comparada com o bacalhau que recebeu alimentação. A redução dos lipídios, principalmente os ácidos graxos polinsaturados foi observada durante o período de privação alimentar. Conseqüentemente também foi reduzida a formação dos precursores dos componentes do flavour durante o armazenamento congelado (Ross \& Love, 1979).

O efeito da privação alimentar também foi estudado por Satoh et al. (1984) em Tilapia nilotica previamente alimentada com uma dieta comercial suplementada com óleo de milho, e em seguida mantida em jejum por 82 dias, em tanques com temperaturas de 15 e $20^{\circ} \mathrm{C}$. A composição de ácidos graxos não se alterou em ambas as temperaturas, porém a porcentagem de $\mathrm{C} 18: 2 \omega 6$ diminuiu em peixes que permaneceram em temperaturas mais baixas $\left(15^{\circ} \mathrm{C}\right)$.

Segundo Beraquet \& Lindo (1985) a fração lipídica do pescado é mais rapidamente oxidada do que a de outros alimentos, por apresentar grande quantidade de ácidos graxos altamente insaturados, particularmente C20:5 e C22:6, estes são oxidados mais rapidamente, com o aumento no número de ligações duplas (Beltrán, 1992).

Os ácidos graxos insaturados são suscetíveis à oxidação pela presença do $\mathrm{O}_{2}$; bem como a época de captura dos peixes pode exercer efeito significativo sobre a composição de alguns ácidos graxos, como olêico e linolênico (Beirão et al., 2000). Alguns autores atribuem essas variações à hidrólise dos fosfolipídeos, eventualmente induzindo ao aumento de ácidos graxos livres (De Koning \& Mol, 1990).

A oxidação é uma das principais causas de deterioração da qualidade dos produtos cárneos. A susceptibilidade do tecido muscular à oxidação deve-se à alta 
concentração de catalisadores (ferro e mioglobina) e aos lipídeos componentes de carne. Uma vez oxidados, os lipídeos reagem com outros componentes, como as proteínas, carboidratos e vitaminas (Hultin, 1994; Cândido et al., 1998).

Steiner-Asiedu et al. (1991) encontraram os seguintes valores de ácidos graxos para tilápia (Tilapia sp), $41 \mathrm{~g} / 100 \mathrm{~g}$ de saturados; $36,3 \mathrm{~g} / 100 \mathrm{~g}$ de monoinsaturados e $14,1 \mathrm{~g} / 100 \mathrm{~g}$ de polinsaturados.

Maia \& Rodriguez-Amaya (1993) e Maia et al. (1994) analisando a tilápia (Oreochromis niloticus) e o curimbatá (Prochilodus scrofa), respectivamente, em relação à composição de ácidos graxos, encontraram valores de $41,7 \mathrm{~g} / 100 \mathrm{~g}$ de saturados; 40,9 g/100g de monoinsaturados e 17,4 g/100g de polinsaturados para a tilápia. Para o curimbatá foram encontrados os seguintes valores: $42 \mathrm{~g} / 100 \mathrm{~g}$ de saturados; $36 \mathrm{~g} / 100 \mathrm{~g}$ de monoinsaturados e $21 \mathrm{~g} / 100 \mathrm{~g}$ de polinsaturados.

Rahman et al. (1994) extraíram os lipídeos de vinte espécies de pescado de água doce da Malásia, e dentre elas, a tilápia (Oreochromis mossabicus). Os autores analisaram a composição de ácidos graxos e encontraram valores de 35,1 g/100g para ácidos graxos saturados; 26,6 g/100g para monoinsaturados e 18,4 g/100g para polinsaturados.

Três espécies de pescado foram analisadas por Ogawa \& Maia (1999), quanto ao conteúdo de ácidos graxos: barbus (Barbus carnaticus), cobra-do-mar (Ophichthidae) e tilápia (Tilapia mossambica). Foram encontrados teores de 33,7 a 49,3 g/100g para saturados; 29,9 a $37,5 \mathrm{~g} / 100 \mathrm{~g}$ de monoinsaturados e 18,1 a $33,2 \mathrm{~g} / 100 \mathrm{~g}$ de polinsaturados.

Siqueira (2001) em pesquisa com tilápia do Nilo irradiada (Oreochromis niloticus), utilizando doses de $1,2,2$ e $5 \mathrm{kGy}$, detectou os seguintes valores: 33 a $52 \mathrm{~g} / 100 \mathrm{~g}$ para ácidos graxos saturados; 39,9 a 44,6 g/100g para monoinsaturados e 7,2 a $22,9 \mathrm{~g} / 100 \mathrm{~g}$ para polinsaturados.

Moreira et al. (2001) determinaram o conteúdo de ácidos graxos de três espécies de pescado brasileiro: matrinchã (Brycon cephalus), piraputunga (Brycon microlepis), e piracanjuba (Brycon orbignyanus). Foram encontrados os seguintes valores: 33,63 a 41,86 g/100g para ácidos graxos saturados; 46,97 a 57,20 g/100g de monoinsaturados e 
6,54 a $17,88 \mathrm{~g} / 100 \mathrm{~g}$ para polinsaturados.

\subsection{Análises microbiológicas}

O Compêndio de Normas e Padrões para Alimentos (BRASIL, 2001a) estabelece para o pescado in natura e refrigerado, os seguintes padrões microbiológicos: Salmonella, ausência em $25 \mathrm{~g}$ e Estafilococos coagulase (+), máximo de $10^{3} / \mathrm{g}$. A Portaria nº 451, revogada em 19/09/97 do Ministério da Saúde (BRASIL, 1997), fixava valores para coliformes fecais, no máximo de $10^{2} / \mathrm{g}$.

\subsubsection{Análise da água de cultivo}

A Tabela 11 apresenta os valores da contagem de coliformes totais e E. coli presentes na água de cultivo de tilápias nos meses de outubro, março e abril. A legislação brasileira estabelece limites de $\leq 2 \times 10^{4}$ para coliformes totais, e $\leq 4 \times 10^{3}$ para coliformes fecais/100 mL de água, destinada à preservação de peixes em geral e de outros elementos da fauna e flora (BRASIL, 2002c).

Tabela 11. NMP/100mL de coliformes totais e E. coli em água de cultivo.

\begin{tabular}{ccc}
\hline Amostras & Coliformes Totais & E. coli \\
\hline Outubro & $>2,4 \times 10^{3}$ & $1,3 \times 10^{1}$ \\
Março & $3,3 \times 10^{1}$ & 0 \\
Abril & $3,3 \times 10^{1}$ & 0 \\
\hline
\end{tabular}

Nota: Médias de 2 repetições.

A microbiota do pescado depende, em grande parte, do grau de contaminação da água em que habita. O grupo coliforme é bastante usado para identificar a qualidade bacteriológica da água, e a presença de E. coli tem sido associada à contaminação de origem fecal.

Segundo Telles (1975), o grupo de bactérias coliformes fecais indica a contaminação da água por dejetos e descargas de esgotos. Frost já havia observado em 
1916, que 85 a 95\% das amostras de água de rio apresentavam coliformes fecais (Frost, 1916).

A água de cultivo do pescado utilizado nesta pesquisa é proveniente do rio Tietê, e nos meses de seca há um menor fluxo das águas, ocorrendo uma maior concentração de microrganismos. Esta pode ser a explicação para a maior contaminação ocorrida no mês de outubro, porém o número de coliformes totais e E. coli esteve dentro dos padrões estabelecidos pela legislação brasileira.

Caland-Noronha \& Moris (1972) relataram que as águas marinhas costeiras de Fortaleza, CE apresentavam valores de coliformes fecais de 2,54 a 3,38 log NMP/mL, indicando contaminação decorrente da afluência de esgotos sanitários e industriais.

De acordo com Leitão et al. (1985) a presença de bactérias coliformes parece ser comum em peixes fluviais e lacustres.

\subsubsection{Avaliação da qualidade da água de depuração de tilápias}

As tilápias, como são peixes tropicais, apresentam conforto térmico à temperatura de $15-35^{\circ} \mathrm{C}$. Temperaturas entre 38 a $44^{\circ} \mathrm{C}$ e 8 a $13^{\circ} \mathrm{C}$ são letais. Já o $\mathrm{pH}$ da água de cultivo deve ser mantido entre 6 a 8,5 (Kubitza, 2000). Na Tabela 12 pode-se observar os parâmetros microbiológicos e físico-químicos da água de depuração.

Tabela 12. NMP/100mL de coliformes totais, E. coli e características físico-químicas da água de depuração das tilápias.

\begin{tabular}{ccccc}
\hline Coliformes Totais & E. coli & Temperatura $\left({ }^{\circ} \mathrm{C}\right)$ & $\mathrm{pH}$ & $\begin{array}{c}\text { Condutividade } \\
\text { Elétrica (CE) (dS/m) }\end{array}$ \\
\hline 4 & 0 & $25-26$ & 8,2 & 2,15 \\
\hline
\end{tabular}

$\mathrm{d} S=$ deciSiemens;

Nota: Médias de 2 repetições.

A tilápia é uma espécie considerada tolerante, uma vez que resiste a condutividade de 15 a $20 \mathrm{dS} / \mathrm{m}$. Segundo Molle \& Cadier (1992) a condutividade 
elétrica da água é medida pela sua capacidade em conduzir electricidade, e depende da quantidade de íons nela contidos, constituindo um bom indicador da concentração total de sais na água.

A água de depuração apresentou baixo número de coliformes totais, e não foi detectada a presença de E. coli.

\subsubsection{Coliformes totais e $E$. coli}

A Tabela 13 apresenta os dados do NMP/g de coliformes totais em filés de tilápia durante o período de armazenamento. O número de coliformes totais não foi afetado significativamente (Teste F) pelos tratamentos e pelo período de armazenamento. Todos os tratamentos apresentaram valores dentro dos padrões estabelecidos pela legislação brasileira. Somente o tratamento a vácuo permitiu o crescimento de coliformes totais, já os demais tratamentos apresentaram um decréscimo, provavelmente devido à combinação das baixas temperaturas de armazenamento, à presença do ácido acético e ao nível de $\mathrm{CO}_{2}$ utilizado.

Tabela 13. Contagem de coliformes totais (NMP/g) em filés de tilápia mantidos sob refrigeração a $1 \pm 1^{\circ} \mathrm{C}$, durante 20 dias.

\begin{tabular}{ccccccc}
\hline \multirow{2}{*}{$\begin{array}{c}\text { Armazenamento } \\
\text { (Dias) }\end{array}$} & Controle & $\begin{array}{c}\text { Ácido } \\
\text { Acético }\end{array}$ & Vácuo & $\begin{array}{c}\text { Vácuo + Ác. } \\
\text { Acético }\end{array}$ & EAM & $\begin{array}{c}\text { EAM + Ác. } \\
\text { Acético }\end{array}$ \\
\cline { 2 - 7 } & $3,2 \times 10^{1}$ & $<2$ & $3,3 \times 10^{1}$ & $<2$ & $3,2 \times 10^{1}$ & $<2$ \\
7 & $1,6 \times 10^{1}$ & $<2$ & $0,3 \times 10^{1}$ & $<2$ & $<2$ & $<2$ \\
13 & $<2$ & $<2$ & $1,4 \times 10^{1}$ & $<2$ & $0,4 \times 10^{1}$ & $0,5 \times 10^{1}$ \\
20 & $<2$ & $<2$ & $1,0 \times 10^{2}$ & $<2$ & $<2$ & $<2$ \\
\hline
\end{tabular}

EAM: Embalagem sob atmosfera modificada com $60 \% \mathrm{CO}_{2}+40 \% \mathrm{O}_{2}$; F/Armazenamento $=0,80$ n.s.; F/Tratamento $=1,84$ n.s.; F/Interação= 0,94 n.s.; C.V. $=366,66 \%$.

Nota: Médias de 3 repetições.

Reddy et al. (1994) relataram que níveis $\geq 50 \%$ de $\mathrm{CO}_{2}$ retardaram o crescimento de coliformes em filés de tilápia (Tilapia spp) armazenada em EAM. 
Segundo Passy et al. (1983) a utilização de EAM com $100 \%$ de $\mathrm{CO}_{2}$ inibiu o crescimento de coliformes da ordem de $9 \times 10^{4}$ para $5 \times 10^{4} \mathrm{UFC} / \mathrm{g}$, em camarão de água doce (Macrobrachium rosenbergii) mantido a $4^{\circ} \mathrm{C}$, durante 11 dias.

Hong et al. (1996) relataram a presença de coliformes da ordem de 1,0 a 1,3 log UFC/g em cavala do Atlântico (Scomber scombrus), armazenada em EAM com 100\% de $\mathrm{CO}_{2}, \mathrm{a}-2^{\circ} \mathrm{C}$, após 21 dias.

Filés de tilápia (Oreochromis niloticus) tratados com solução de ácido lático a $10 \%$ continham valores iniciais de $0,60 \log \mathrm{NMP} / \mathrm{g}$; atingiram 4,17 log NMP/g, depois de 8 dias de armazenamento a $4-10^{\circ} \mathrm{C}$ (Lima et al., 1998).

Krolow et al. (2000) observaram que filés de carpa (Cyprinus carpio) que foram depurados apresentaram uma menor contagem para coliformes totais, da ordem de $4,3 \times 10^{1} \mathrm{NMP} / \mathrm{g}$, quando comparados com os não depurados, cuja contagem alcançou $2,3 \times 10^{2} \mathrm{NMP} / \mathrm{g}$.

Não foi detectada a presença de E. coli em nenhuma amostra durante o período de armazenamento. Isso provavelmente ocorreu em virtude das tilápias terem passado por um período de depuração que permitiu a limpeza do trato gastrintestinal, evitando desse modo a contaminação durante o abate, além da água do local de cultivo apresentar baixa contaminação por este tipo de bactéria. Resultados semelhantes também foram observados por Lima et al. (1998) em filés de tilápia do Nilo (Oreochromis niloticus) tratados com ácido lático a $10 \%$ e armazenados a $4-10^{\circ} \mathrm{C}$.

Os coliformes fecais e a $E$. coli são utilizados na avaliação da qualidade higiênico-sanitária dos alimentos. De acordo com Jay (1986) as bactérias do grupo coliforme são mesófilas, mas podem crescer a temperaturas de $-2^{\circ} \mathrm{C}$. Porém, a temperaturas inferiores a $5^{\circ} \mathrm{C}$ propiciam um crescimento muito lento.

Vieira et al. (1986) também não observaram aumento progressivo no número de coliformes totais e fecais, em experimento com lagostas estocadas sob gelo (Pacifastacus spp), porém os mesmos apresentaram um comportando irregular. Isso pode ser explicado, pelo fato de os coliformes fecais serem mesófilos, e dessa forma inibidos pela baixa temperatura $\left(0^{\circ} \mathrm{C}\right)$ (Mujica, 1988). 
Tilápias (Oreochromis niloticus) recém capturadas foram analisadas, quanto à presença de coliformes totais, coliformes fecais e E. coli, por Vieira et al. (2000). Todas as amostras apresentaram um valor mínimo de $3 \mathrm{NMP} / \mathrm{g}$, para todas as bactérias.

Williams et al. (1995) observaram o decréscimo na contagem de coliformes totais e fecais da ordem de 2,9 para 0,9 log UFC/g, em amostras de "catfish" (Ictalurus nebulosus) tratadas com $2 \%$ de $\mathrm{NaCl}$, embaladas a vácuo e mantidas a $1,11 \pm 1{ }^{\circ} \mathrm{C}$, durante 8 dias.

\subsubsection{Psicrotróficos}

A Tabela 14 e a Figura 22 apresentam os dados da variação de bactérias psicrotróficas em filés de tilápia durante o período de armazenamento. A contagem de bactérias psicrotróficas não foi afetada significativamente (Teste F) pelos tratamentos e pelo período de armazenamento; o controle atingiu níveis superiores a $10^{6} \mathrm{UFC/g}$. Embora a legislação brasileira não contemple o limite para psicrotróficos, contagens elevadas desse grupo de bactérias, com certeza contribuem para a redução da vida útil do produto. A elevada contagem de psicrotróficos para o controle, também está relacionada com o aumento de $\mathrm{pH}$; embora o produto tenha sido aceito sensorialmente pelos provadores, pelo fato destes considerarem a aparência, o atributo mais importante.

Tabela 14. Bactérias psicrotróficas (UFC/g) em filés de tilápia mantidos sob refrigeração a $1 \pm 1^{\circ} \mathrm{C}$, durante 20 dias.

\begin{tabular}{ccccccc}
\hline \multirow{2}{*}{$\begin{array}{c}\text { Armazenamento } \\
\text { (Dias) }\end{array}$} & Controle & $\begin{array}{c}\text { Ácido } \\
\text { Acético }\end{array}$ & Vácuo & $\begin{array}{c}\text { Vácuo + Ác. } \\
\text { Acético }\end{array}$ & EAM & $\begin{array}{c}\text { EAM + Ác. } \\
\text { Acético }\end{array}$ \\
\cline { 2 - 7 } & $1,0 \times 10^{2}$ & $1,2 \times 10^{2}$ & $1,2 \times 10^{2}$ & $5,4 \times 10^{3}$ & $2,3 \times 10^{2}$ & $6,2 \times 10^{2}$ \\
7 & $1,4 \times 10^{3}$ & $1,1 \times 10^{3}$ & $1,1 \times 10^{4}$ & $7,2 \times 10^{2}$ & $1,7 \times 10^{3}$ & $7,5 \times 10^{2}$ \\
13 & $6,8 \times 10^{5}$ & $1,9 \times 10^{3}$ & $4,3 \times 10^{5}$ & $2,5 \times 10^{3}$ & $1,9 \times 10^{3}$ & $3,0 \times 10^{2}$ \\
20 & $1,8 \times 10^{7}$ & $1,3 \times 10^{5}$ & $9,6 \times 10^{6}$ & $7,0 \times 10^{4}$ & $3,0 \times 10^{4}$ & $5,3 \times 10^{3}$ \\
\hline
\end{tabular}

EAM: Embalagem sob atmosfera modificada com $60 \% \mathrm{CO}_{2} ; \mathrm{F} /$ Armazenamento= 1,98 n.s.; F/Tratamento= 0,98 n.s.; F/Interação= 0,89 n.s.; C.V.=571,48\%.

Nota: Médias de 3 repetições. 


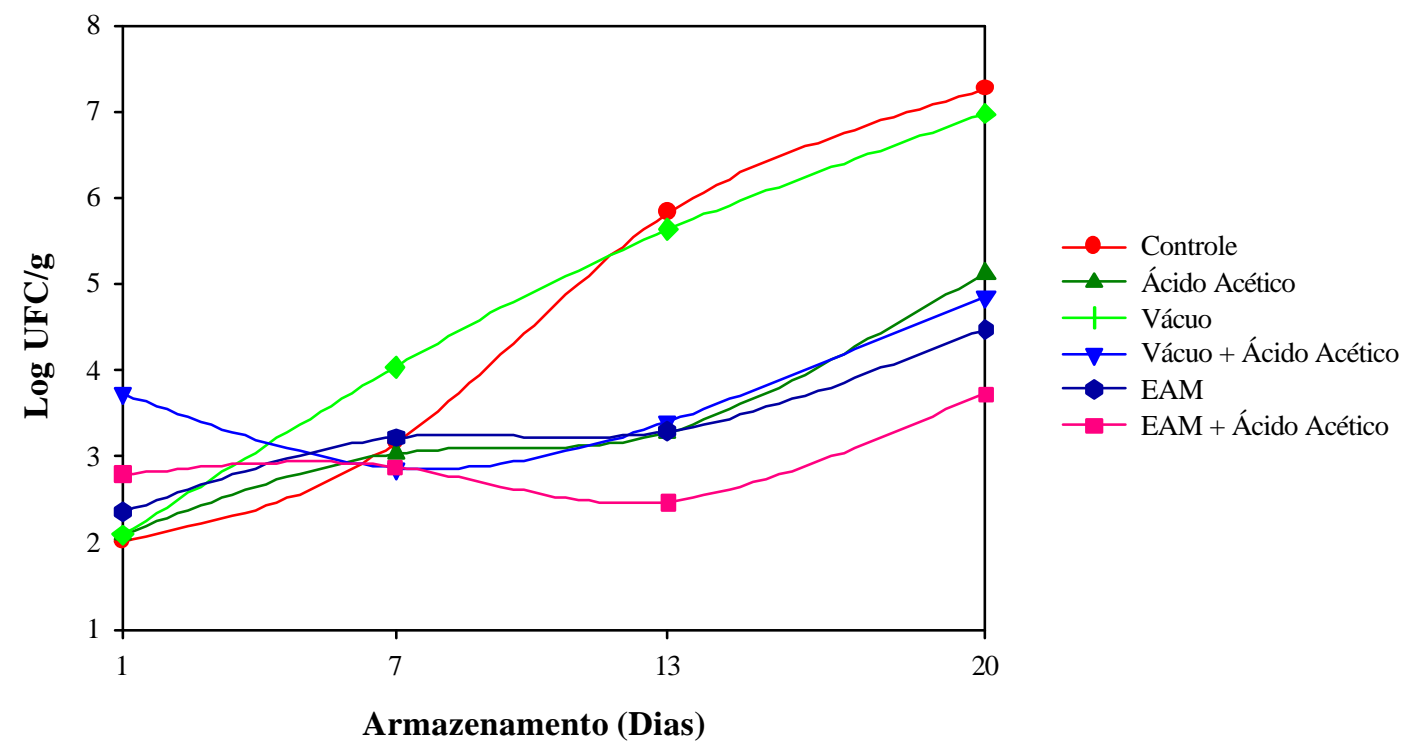

Figura 22 - Bactérias psicrotróficas (log UFC/g) em filés de tilápia mantidos sob refrigeração a $1 \pm 1^{\circ} \mathrm{C}$, durante 20 dias.

As bactérias psicrotróficas utilizam para seu desenvolvimento os compostos não protéicos; seu crescimento é incrementado na presença de substâncias nitrogenadas não protéicas e em condições de pH alto (> 6,0) (Gram \& Huss, 1996; Liston, 1982).

A embalagem a vácuo e a EAM, associadas ao ácido acético apresentaram um decréscimo das bactérias psicrotróficas no $7^{\underline{0}}$ e no $13^{\underline{0}}$ dia de armazenamento, respectivamente, estando este fato relacionado também com o decréscimo de $\mathrm{pH}$. A EAM foi o tratamento que apresentou a menor contagem ao término do período de armazenamento. Provavelmente, isso ocorreu devido à alta concentração de $\mathrm{CO}_{2}$, associada ao emprego do ácido acético, pelo fato de serem agentes bacteriostáticos.

Segundo Marel et al. (1998) a aplicação superficial de ácidos orgânicos é um tratamento utilizado na descontaminação da carne, e tem como objetivo principal a redução de microrganismos deterioradores e patogênicos, naturalmente presentes em alimentos. 
Os valores encontrados para psicrotróficos nos tratamentos com ácido acético, vácuo e o controle, foram semelhantes aos encontrados por Randell et al. (1999) em filés de salmão do Atlântico (Salmo salar) armazenados a $2^{\circ} \mathrm{C}$ em EAM, contendo $60 \% \mathrm{CO}_{2}+40 \% \mathrm{~N}_{2}$, embalagem a vácuo e embalagem tipo overwrap.

Em filés de bacalhau (Gadus morhua) armazenados com $25 \% \mathrm{CO}_{2}+75 \% \mathrm{~N}_{2}$, durante 20 dias à temperatura de $0 \pm 1{ }^{\circ} \mathrm{C}$, o incremento na contagem microbina foi significativo, durante o período de armazenamento, atingindo valores de 4,25 a 5,5 $\log$ UFC/g (Villemure et al., 1986).

Segundo Cai et al. (1997) a mudança do ambiente poderá resultar em possível crescimento de bactérias aneróbias facultativas e anaeróbias em embalagens tipo overwrapped, por se ter uma área livre de $\mathrm{O}_{2}$ entre os filés. Para o tratamento embalado a vácuo, nesta pesquisa, a explicação para o crescimento de bactérias psicrotróficas aeróbias, é possivelmente devido à sensibilidade do filme EVOH à alta umidade do produto, que pode ter comprometido suas propriedades de barreira aos gases.

Shewan (1977) relata que as bactérias predominantes no pescado fresco, bem como no estado deteriorado, são as bactérias psicrotróficas Gram-negativas, especialmente quando o pescado encontra-se armazenado à temperatura próxima de $0^{\circ} \mathrm{C}$. Portanto, independente da microbiota inicial, a microbiota final consistirá da presença de Pseudomonas, que se desenvolvem bem a baixas temperaturas.

De acordo com Silliker \& Wolfe (1980) o crescimento de psicrotróficos é inibido pelas altas concentrações de $\mathrm{CO}_{2}$, quando o pescado é armazenado em baixas temperaturas, indicando que as bactérias psicrotróficas são sensíveis ao $\mathrm{CO}_{2}$. Reddy et al. (1992) e Silva et al. (1993) acreditam que este fato ocorre porque a fase logarítmica é retardada.

Leitão (1988) relatou que a intensidade da contaminação do pescado depende de inúmeros fatores, tais como temperatura, grau de poluição das águas e vísceras repletas ou não de alimentos, situações em que a população bacteriana varia entre $10^{2}$ a $10^{5}$ $\mathrm{UFC} / \mathrm{cm}^{2}$ na superficie, $10^{3}$ a $10^{7} \mathrm{UFC} / \mathrm{g}$ nas guelras e 10 a $10^{8} \mathrm{UFC} / \mathrm{g}$ nas vísceras de espécies de pescado capturadas em diversas condições. 


\subsubsection{Staphylococcus aureus}

A Tabela 15 apresenta os resultados da contagem de $S$. aureus em filés de tilápia durante o período de armazenamento. A contagem de $S$. aureus não foi afetada significativamente (Teste F) pelos tratamentos e pelo período de armazenamento. Nenhum dos tratamentos apresentou valores acima dos estabelecidos pela legislação brasileira. Todos os tratamentos apresentaram um decréscimo na contagem de S. aureus, exceto o tratamento a vácuo, que no $7^{\underline{0}}$ dia de armazenamento apresentou uma contagem mais elevada.

Tabela 15. Staphylococcus aureus (UFC/g) em filés de tilápia mantidos sob refrigeração a $1 \pm 1^{\circ} \mathrm{C}$, durante 20 dias.

\begin{tabular}{ccccccc}
\hline \multirow{2}{*}{$\begin{array}{c}\text { Armazenamento } \\
\text { (Dias) }\end{array}$} & Controle & $\begin{array}{c}\text { Ácido } \\
\text { Acético }\end{array}$ & Vácuo & $\begin{array}{c}\text { Vácuo + Ác. } \\
\text { Acético }\end{array}$ & EAM & $\begin{array}{c}\text { EAM + Ác. } \\
\text { Acético }\end{array}$ \\
\cline { 2 - 7 } & $1,0 \times 10^{2}$ & $5,3 \times 10^{1}$ & $5,3 \times 10^{1}$ & $1,7 \times 10^{1}$ & $4,3 \times 10^{1}$ & $3,0 \times 10^{1}$ \\
7 & $9,0 \times 10^{1}$ & $6,7 \times 10^{1}$ & $3,1 \times 10^{2}$ & $2,3 \times 10^{1}$ & $3,7 \times 10^{1}$ & $1,7 \times 10^{1}$ \\
13 & $<10$ & $5,7 \times 10^{1}$ & $8,7 \times 10^{1}$ & $<10$ & $<10$ & $<10$ \\
20 & $<10$ & $<10$ & $<10$ & $<10$ & $<10$ & $<10$ \\
\hline
\end{tabular}

EAM: Embalagem sob atmosfera modificada com $60 \% \mathrm{CO}_{2}+\mathrm{O}_{2} ; \quad \mathrm{F} /$ Armazenamento $=1,82$ n.s.; F/Tratamento $=1,36$ n.s.; F/Interação= 0,67 n.s.; C.V.=292,98\%.

Nota: Médias de 3 repetições.

Os resultados obtidos no presente trabalho diferem daqueles obtidos por Passy et al. (1983) que observaram que o camarão de água doce (Macrobrachium rosenbergii) armazenado sob $100 \%$ de $\mathrm{CO}_{2}$ apresentou um aumento de $10^{1}$ a $10^{2} \mathrm{UFC} / \mathrm{g}$ para $10^{3}$ a $10^{4} \mathrm{UFC} / \mathrm{g}$, após de 12 dias de armazenamento a $4^{\circ} \mathrm{C}$.

De acordo com Martin et al. (1978) como S. aureus tem seu principal habitat na pele, mucosas nasais e trato respiratório humano, a sua presença indica o manuseio inadequado do alimento, equipamentos mal higienizados, contaminação após o processamento de fontes humanas ou de animais. 
Tilápias (Oreochromis niloticus) recém capturadas foram analisadas, quanto à presença de S. aureus, por Vieira et al. (2000). Todas as amostras apresentaram valores que variaram de $<10$ a $10,6 \times 10^{2} \mathrm{UFC} / \mathrm{g}$.

Wang \& Ogrydziak (1986) não detectaram a presença de S. aureus em amostras de bacalhau (Gadus morhua) com $80 \%$ de $\mathrm{CO}_{2}$, após de 14 dias de armazenamento, a $4^{\circ} \mathrm{C}$.

O $S$. aureus é uma bactéria anaeróbia facultativa, mas prefere metabolismos aeróbicos (Hintlian \& Hotchkiss, 1986). E a sua presença em pescado tem sido associada a águas contaminadas (Liston, 1963).

\subsubsection{Salmonella spp e Clostridium sulfito-redutores}

Não foi detectada a presença de Salmonella e Clostridium sulfito-redutores em nenhuma amostra analisada durante o experimento.

Passy et al. (1983), Silva \& White (1994) e Randell et al. (1999) também não detectaram a presença dessas bactérias em camarão de água doce (Macrobrachium rosenbergii), "catfish" (Ictalurus punctatus) e salmão do Atlântico (Salmo salar), durante 2 semanas de armazenamento em EAM.

De acordo com Leitão (1977) o habitat da Salmonella é o trato intestinal, e a sua presença indica provável contaminação fecal de fontes humanas ou animais. Peixes capturados em águas não poluídas estão isentos de Salmonella, pelo fato desta não fazer parte da microbiota natural do pescado, sendo sua presença neste alimento oriunda, principalmente do manuseio ou do contato com superfícies inadequadamente higienizadas. Além disso, essa bactéria dificilmente prolifera em alimentos contendo outros microrganismos. A presença de Salmonella em um alimento é razão suficiente para que o mesmo seja condenado.

Vieira et al. (1986) estudando a conservação de caudas de lagostas (Pacifastacus spp) estocadas sob gelo, observaram que não houve a ocorrência de Salmonella em nenhuma das amostras analisadas.

Andrews et al. (1976) observaram a presença de Salmonella em mariscos (Mercenaria mercenaria) provenientes de águas contaminadas, da ordem de 1,51 a 3,36 
$\log \mathrm{NMP} / \mathrm{g}$ para coliformes fecais. A presença deste microrganismo em pescado está associada às águas contaminadas.

Pacus (Piaractus mesopotamicus) comercializados em Cuiabá, MT foram analisados quanto à presença de Salmonella, nos rios e em locais de cultivo, por Lima \& Reis (2000). Os autores compararam metodologias para isolamento de cepas e fizeram coletas das amostras nos locais de captura e de criação, nas feiras e nos supermercados e observaram contaminação em 35\% das amostras, destas $70 \%$ provenientes de criatórios.

\subsection{Análise sensorial}

As notas médias atribuídas pelos provadores, para os atributos cor, aroma, textura e aparência podem ser observadas na Tabela 16 e nas Figuras 23, 24, 25 e 26. Todos os atributos, exceto a textura, foram afetados significativamente $(\mathrm{p}<0,05)$ pelos tratamentos durante o período de armazenamento.

De acordo com os resultados da avaliação sensorial, os filés submetidos ao prétratamento com ácido acético e embalados em EAM foram considerados inaceitáveis para o consumo a partir do $7^{0}$ dia, com notas inferiores a 5 , para os atributos cor, aroma e aparência. Os tratamentos sob EAM + ácido acético e o com ácido acético foram considerados aceitáveis para o consumo até $13^{\underline{0}}$ dia de armazenamento. Desde o primeiro dia de avaliação, os provadores perceberam que os filés submetidos ao prétratamento com ácido acético e ao embalamento em EAM apresentavam textura pouco firme, coloração esbranquiçada e exsudação, quando comparados aos demais tratamentos.

A partir do sétimo dia de avaliação sensorial, alguns provadores perceberam o ranço nos tratamentos com ácido acético, EAM e EAM + ácido acético, estando relacionados com o aumento nos valores de TBA. Porém no tratamento a vácuo + ácido acético, a presença de ranço foi detectada somente no último dia de avaliação, provavelmente devido à baixa concentração de $\mathrm{O}_{2}$, retardando o processo oxidativo dos ácidos graxos polinsaturados. 
Tabela 16. Cor, aroma, textura e aparência em filés de tilápia mantidos sob refrigeração a $1 \pm 1{ }^{\circ} \mathrm{C}$, durante 20 dias - notas (médias) atribuídas pela equipe sensorial.

\begin{tabular}{|c|c|c|c|c|c|c|}
\hline \multirow{2}{*}{$\begin{array}{l}\text { Armazenamento } \\
\text { (Dias) }\end{array}$} & \multicolumn{6}{|c|}{ Tratamentos } \\
\hline & Controle & $\begin{array}{l}\text { Ácido } \\
\text { Acético }\end{array}$ & Vácuo & $\begin{array}{c}\text { Vácuo + Ác. } \\
\text { Acético }\end{array}$ & EAM & $\begin{array}{c}\text { EAM + Ác. } \\
\text { Acético }\end{array}$ \\
\hline \multicolumn{7}{|c|}{ Cor } \\
\hline 1 & $6,40 \mathrm{a}$ & $7,00 \mathrm{a}$ & $7,40 \mathrm{a}$ & $5,90 \mathrm{a}$ & $6,90 a$ & $6,90 \mathrm{a}$ \\
\hline 7 & $6,70 \mathrm{ab}$ & $5,50 \mathrm{~b}$ & $7,90 \mathrm{a}$ & $6,40 \mathrm{~b}$ & $6,60 \mathrm{ab}$ & $4,20 \mathrm{c}$ \\
\hline 13 & $7,50 \mathrm{a}$ & $4,00 \mathrm{~b}$ & $6,90 \mathrm{a}$ & $6,80 \mathrm{a}$ & $6,60 \mathrm{a}$ & $3,10 \mathrm{~b}$ \\
\hline 20 & $6,40 \mathrm{a}$ & $4,50 \mathrm{ab}$ & $6,70 \mathrm{a}$ & $5,80 \mathrm{ab}$ & $4,10 \mathrm{ab}$ & $2,90 \mathrm{~b}$ \\
\hline \multicolumn{7}{|c|}{ Aroma } \\
\hline 1 & $7,10 \mathrm{a}$ & $6,50 \mathrm{a}$ & $6,90 \mathrm{a}$ & $5,70 \mathrm{a}$ & $6,60 \mathrm{a}$ & $6,10 \mathrm{a}$ \\
\hline 7 & $6,00 \mathrm{a}$ & $5,00 \mathrm{a}$ & $6,40 \mathrm{a}$ & $5,90 \mathrm{a}$ & $6,20 \mathrm{a}$ & $4,50 \mathrm{a}$ \\
\hline 13 & $6,40 \mathrm{a}$ & $5,10 \mathrm{ab}$ & $5,70 \mathrm{ab}$ & $6,10 \mathrm{a}$ & $5,50 \mathrm{ab}$ & $3,90 \mathrm{~b}$ \\
\hline 20 & $5,90 \mathrm{a}$ & $3,70 b c$ & 4,90abc & $5,30 \mathrm{ab}$ & $2,90 \mathrm{c}$ & $3,30 b c$ \\
\hline \multicolumn{7}{|c|}{ Textura } \\
\hline 1 & $7,30 \mathrm{a}$ & $7,80 \mathrm{a}$ & $7,90 \mathrm{a}$ & $6,60 \mathrm{a}$ & $7,40 \mathrm{a}$ & $7,00 \mathrm{a}$ \\
\hline 7 & $6,70 \mathrm{a}$ & $6,50 \mathrm{a}$ & $7,10 \mathrm{a}$ & $7,50 \mathrm{a}$ & $6,90 \mathrm{a}$ & $6,10 \mathrm{a}$ \\
\hline 13 & $6,90 \mathrm{a}$ & $5,30 \mathrm{a}$ & $6,80 \mathrm{a}$ & $7,00 \mathrm{a}$ & $6,70 \mathrm{a}$ & $5,30 \mathrm{a}$ \\
\hline 20 & $6,90 \mathrm{a}$ & $5,70 \mathrm{a}$ & $6,30 \mathrm{a}$ & $6,70 \mathrm{a}$ & $5,00 \mathrm{a}$ & $4,70 \mathrm{a}$ \\
\hline \multicolumn{7}{|c|}{ Aparência } \\
\hline 1 & $6,80 \mathrm{a}$ & $7,30 \mathrm{a}$ & $7,50 \mathrm{a}$ & $6,20 \mathrm{a}$ & $6,70 \mathrm{a}$ & $6,70 a$ \\
\hline 7 & $6,20 \mathrm{a}$ & $5,30 \mathrm{ab}$ & $7,20 \mathrm{a}$ & $6,10 \mathrm{ab}$ & $6,40 \mathrm{a}$ & $4,50 \mathrm{~b}$ \\
\hline 13 & $6,90 \mathrm{a}$ & $5,30 \mathrm{a}$ & $6,20 \mathrm{a}$ & $6,30 \mathrm{a}$ & $6,10 \mathrm{a}$ & $3,90 \mathrm{a}$ \\
\hline 20 & $6,30 \mathrm{a}$ & $4,50 \mathrm{ab}$ & $5,30 \mathrm{ab}$ & $6,20 \mathrm{ab}$ & $4,00 \mathrm{ab}$ & $3,10 \mathrm{~b}$ \\
\hline
\end{tabular}

EAM: Embalagem sob amosfera modificada com $60 \% \mathrm{CO}_{2}+40 \% \mathrm{O}_{2}$; Médias seguidas pela mesma letra, minúscula nas linhas, não diferem pelo teste de Tukey a $5 \%$. 


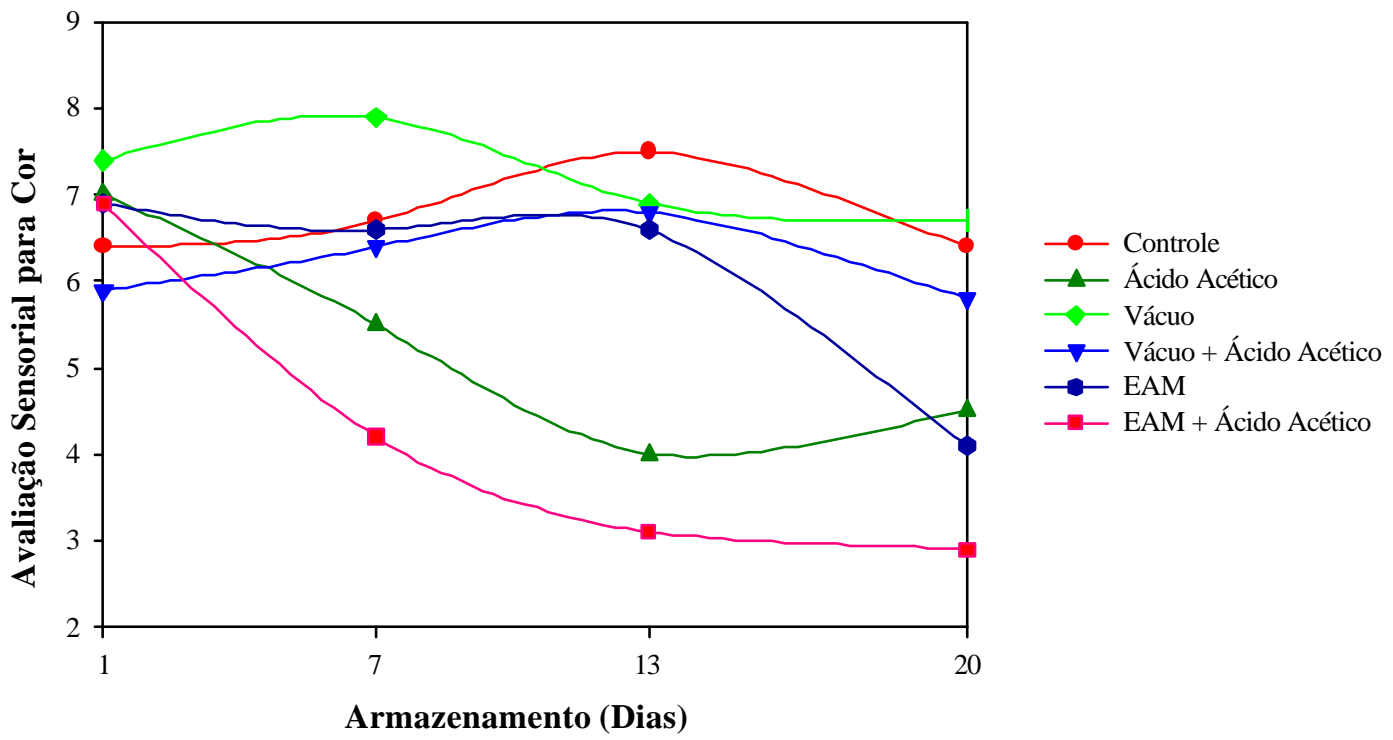

Figura 23 - Cor em filés de tilápia mantidos sob refrigeração a $1 \pm 1^{\circ} \mathrm{C}$, durante 20 dias.

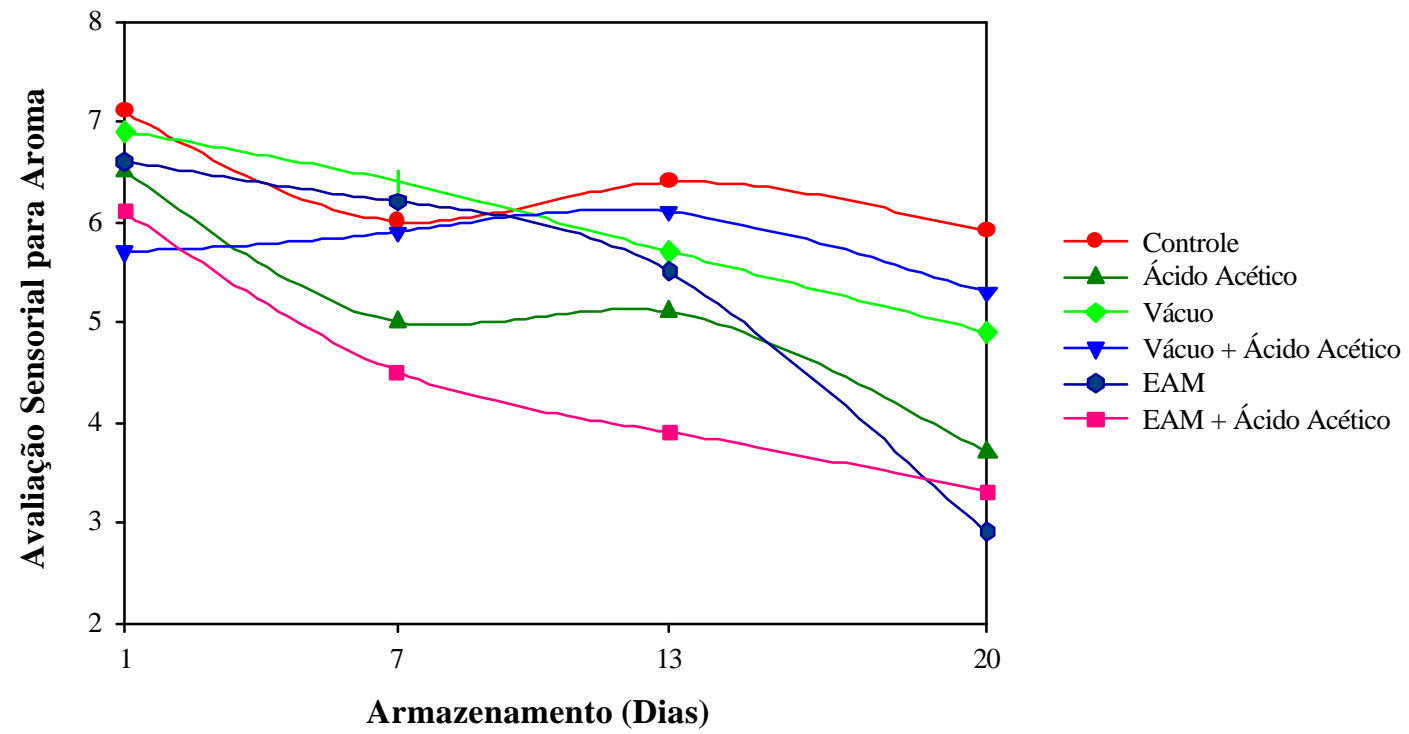

Figura 24 - Aroma em filés de tilápia mantidos sob refrigeração a $1 \pm 1^{\circ} \mathrm{C}$, durante 20 dias. 


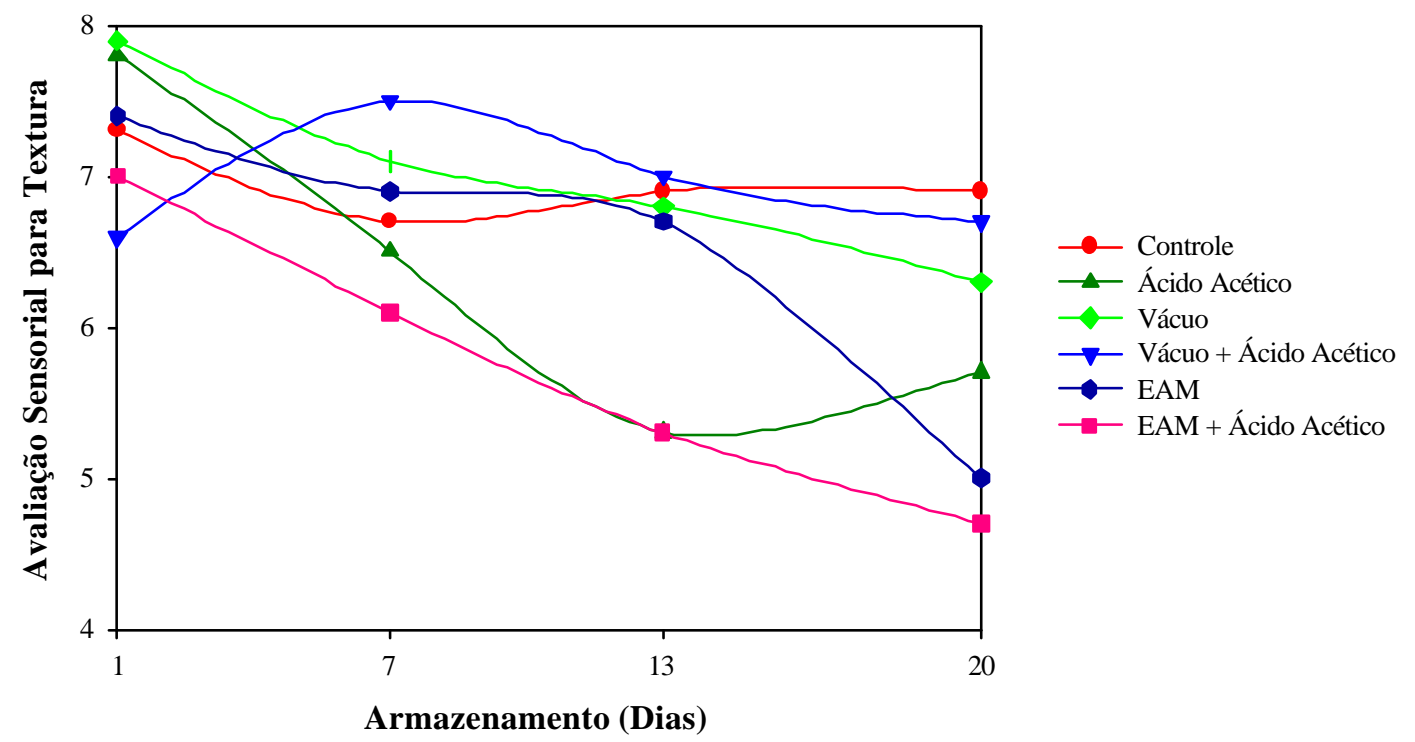

Figura 25 - Textura em filés de tilápia mantidos sob refrigeração a $1 \pm 1{ }^{\circ} \mathrm{C}$, durante 20 dias.

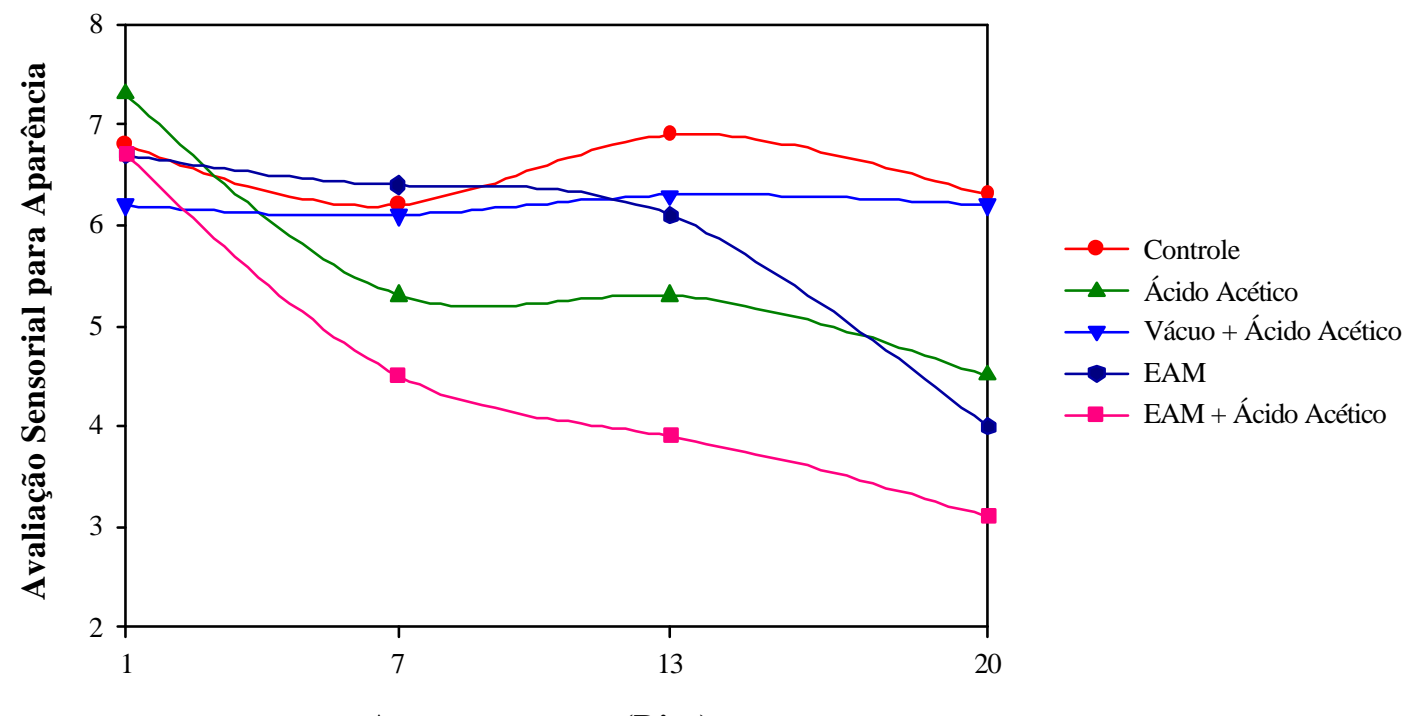

Armazenamento (Dias)

Figura 26 - Aparência em filés de tilápia mantidos sob refrigeração a $1 \pm 1{ }^{\circ} \mathrm{C}$, durante 20 dias. 
Os tratamentos a vácuo e a vácuo associado ao ácido acético foram semelhantes ao controle, sendo considerados aceitáveis até $20^{\underline{0}}$ dia de armazenamento. Embora o controle apresentasse um índice acima de $10^{6} \mathrm{UFC} / \mathrm{g}$ para psicrotróficos, e $\mathrm{pH}$ além do permitido pela legislação brasileira, o fator limitante na rejeição do produto pelo provador, foi a aparência alterada, por modificações produzidas na capacidade de retenção de água e alterações na coloração, pelo efeito do ácido acético e do $\mathrm{O}_{2}$, caracterizada pelo aspecto descolorido e com exsudação. Tais informações estão diretamente correlacionadas com o aumento do TBA, sendo que as mesmas amostras apresentaram odores estranhos e de ranço.

Barnett et al. (1982) também observaram alterações de coloração em salmão (Salmo salar) armazenado em contêineres sob atmosfera com $90 \% \mathrm{CO}_{2}+10 \% \mathrm{O}_{2}$ a $0^{\circ} \mathrm{C}$. Porém, Parkin et al. (1981) em experimento com filés de "rockfish" (Sebastes spp) armazenado em EAM com $80 \% \mathrm{CO}_{2}+10 \% \mathrm{O}_{2}$ a $1,7 \pm 1{ }^{\circ} \mathrm{C}$, não observaram alterações de coloração durante o período de armazenamento.

Mitsuda et al. (1980), em um experimento utilizando os ácidos fórmico, succínico, acético, málico, cítrico, propiônico e lático a $1 \%$ sobre postas de choco (Seriola aurevettata), relataram que todos os ácidos foram muito efetivos, exceto o ácido fórmico que não preveniu a alteração da cor, mas somente o ácido acético permitiu a manutenção da firmeza, semelhante ao controle, durante o período de armazenamento.

No entanto, Mujica (2000) observou menores notas para a textura da carne em filés de cação (Prionace glauca) tratados com ácido acético a 1\%, quando comparado com o controle, provavelmente devido ao efeito do ácido acético sobre os filés, reduzindo o pH destes, e podendo levar a maiores perdas por exsudação, por haver menor capacidade de retenção de água das proteínas em faixas de $\mathrm{pH}$ muito baixas, próximas ao ponto isoelétrico das mesmas, afetando a textura dos filés.

A queda do $\mathrm{pH}$ do músculo de carnes diminui a sua capacidade de retenção de água (Forrest et al., 1975). Segundo Sgarbieri (1996) não é comum que ocorra a degradação das proteínas pela ação dos ácidos, quando o pH está acima de 4,0, mas pode haver a perda de solubilidade daqueles compostos, cujos pontos isoelétricos se encontrem nas faixas de $\mathrm{pH}$ ligeiramente ácido, como é o caso das proteínas da carne. 
A textura do músculo do pescado é afetada por diversos fatores, como a espécie, composição química, idade, condições de manuseio, processamento e estocagem, bem como a estrutura das fibras musculares e os tecidos conectivos (Dunajski, 1979).

Segundo Góes (1987) a textura da tilápia conservada em gelo apresenta alta correlação com a vida útil, determinada por métodos bioquímicos. Embora as características de sabor sejam mais importantes para a aceitação do consumidor, a textura é igualmente importante, quando aliada ao sabor suave, no caso dos consumidores que não consomem pescado com muita frequência (Chambers \& Robel, 1993).

Ruivo (1988) descreveu que o grau de confiança das respostas da análise sensorial está ligada à experiência, à capacidade do analista e ao seu treinamento, além do seu estado emocional ou do que fez antes das análises, como por exemplo, se bebeu ou fumou, por exemplo. As informações obtidas sensorialmente devem ser interpretadas em conjunto com as derivadas das análises fisico-químicas e microbiológicas.

Conforme descrito, por Zottola (1988) a carne é considerada deteriorada quando se apresenta sensorialmente (cor, odor e presença aparente de microrganismos) inaceitável para o consumidor, porém deve-se alertar para o fato de que o aceitável para um indivíduo pode não o ser para outro.

O grau de aceitabilidade de um alimento por parte dos consumidores é afetado por fatores inerentes ao próprio indivíduo e ao ambiente que o circunda. A preferência por um produto está ligada aos hábitos e padrões culturais, além da sensibilidade individual, idade, a fidelidade a determinadas marcas, a higiene e o local de consumo, o tipo e o número de acompanhantes, entre outros aspectos (Dasso, 1999). 


\section{CONCLUSÕES}

Com base nos resultados experimentais obtidos, pode-se concluir que:

- É possível dispor a tecnologia gerada no presente experimento ao setor produtivo de pescado, visando novos produtos, utilizando a tilápia como matéria-prima.

- Em relação æ̀̀ análises físico-químicas e microbiológicas realizadas, observou-se que todos os tratamentos apresentaram-se satisfatórios durante $\mathrm{o}$ período de armazenamento, com exceção do controle que apresentou uma contagem para psicrotróficos acima do considerado aceitável, e valores de $\mathrm{pH}$ acima do permitido pela legislação brasileira, aos 13 e 20 dias de armazenamento, respectivamente.

- Os valores de nitrogênio não protéico - NNP, bases nitrogenadas voláteis totais BNVT e pH apresentaram-se dentro dos limites considerados adequados para o pescado minimamente processado.

- Em relação aos parâmetros microbiológicos e físico-químicos da água de cultivo e depuração, os valores estão de acordo com a legislação brasileira e com as condições adequadas para o crescimento e desenvolvimento de tilápias.

- Não detectou-se a presença de Salmonella, Clostridium sulfito-redutores e E. coli. Os tratamentos em EAM $\left(60 \% \mathrm{CO}_{2}+40 \% \mathrm{O}_{2}\right)$ e a vácuo, associados ou não ao ácido acético (1\%), inibiram o desenvolvimento de $S$. aureus, coliformes totais $\mathrm{e}$ psicrotróficos proporcionando vida útil de 20 dias.

- Para a análise sensorial, observou-se que até aos 20 dias de armazenamento os tratamentos se apresentaram satisfatórios, com exceção dos tratamentos com ácido 
acético, EAM e EAM + ácido acético, estabelecendo-se, entretanto, esse período como limite de validade para este tipo de produto.

- Os filés tratados com ácido acético apresentaram-se descoloridos, com textura menos firme em relação aos demais tratamentos. A EAM associada ou não ao ácido acético apresentou valores mais elevados de TBA, sendo detectada a presença de ranço pelos provadores.

- O embalamento a vácuo associado ao ácido acético foi o tratamento mais estável no que se refere às características físico-químicas, microbiológicas e sensoriais estáveis até o término do experimento.

- A proporção de ácidos graxos saturados decresceu em todos os tratamentos, durante o período de armazenamento, já os monoinsaturados permaneceram mais estáveis; e os polinsaturados aumentaram.

- Os tratamentos embalados a vácuo e em EAM mantiveram valores de aminoácidos mais elevados, quando comparados ao controle, até o término do período de armazenamento. 


\section{REFERÊNCIAS BIBLIOGRÁFICAS}

ADAMS, M.R.; HALL, C.I. Growth inhibition of food-borne pathogens by lactic and acetic acids and their moistures. International Journal of Food Science and Technology, v.23, n.3, p.287-292, 1988.

ANDRADE, A.D.; RUBIRA, A.F.; MATSUSHITA, M.; SOUZA, N.E. $\omega$ fatty acids in freshwater fish from suth Brazil. The Journal of the American Oil Chemists Society, v.72, n.10, p.1207-1210, 1995.

ANDRADE, A.D.; VISENTAINER, J.V.; MATSUSHITA, M.; SOUZA, N.E. Omega-3 fatty acids in baked freshwater fish from suth of Brazil. Archivos Latinoamericanos de Nutricion, v.47, n.1, p.73-76, 1997.

AKANDE, G.R. Technical note: improved utilization of stunded tilapia spp. Journal Food Science and Technology International, v.24, p.20-26, 1989.

AL-KAHTANI, H.A.; ABU-TARBOUSH, H.M.; BAJABER, A.S. et al. Chemical changes after irradiation and post-irradiation storage in tilapia and Spanish mackerel. Journal of Food Science, v.61, n.4, p.729-733, 1996.

AMINULLAH BHUIYAN, A.K.M.; RATNAYAKE, W.M.N.; ACKMAN, R.G. Stability of lipids and polyunsaturated fatty acids during smoking of Atlantic mackarel (Scomber scombrus L.). The Journal of the American Oil Chemists Society, v.63, n.3, p.324-328, 1986. 
ANDREWS, W.H.; DIGGS, C.D.; MIESCIER, J.J.; WILSON, C.R.; ADAMS, W.N.; FURFARI, S.A.; MUSSELMAN, J.F. Validity of members of the total coliform and coliform groups for indicating the presence of salmonella in the quahuag (Mercenaria mercenaria). Journal Milk of Food Technology, v.39, n.5, p.322-324, 1976.

ANTUNES, S.A. Recentes avanços e perspectivas da industrialização do pescado de água doce. In: SIMPÓSIO SOBRE MANEJO E NUTRIÇÃO DE PEIXES. Piracicaba, 1997. Anais. Campinas: CBNA, 1997. p.131-136.

ARAÚJO, M.G.; GASPAR, A.; MONTENEGRO, M. Tempo de prateleira de pescadinha (Cynoscion, spp) resfriada: avaliação quanto aos aspectos físico-químicos e sensoriais. In: CONGRESSO BRASILEIRO DE CIÊNCIA E TECNOLOGIA DE ALIMENTOS, 17., Fortaleza, 2000. Resumos. Fortaleza: SBCTA, 2000. v.1, p.3.187.

ASSOCIATION OF OFFICIAL ANALYTICAL CHEMISTS - AOAC. Official methods of analysis of the Association of Official Analytical Chemists. 16.ed. Arlington, 1995. 2v.

BAKER, D.A.; GENIGEORGIS, C.; GLOVER, J.; RAZAVILAR, V. Growth and toxigenesis of $C$. botulinum type $\mathrm{E}$ in fishes packaged under modified atmospheres. International Journal of Food Microbiology, v.10, n.3, p.269-290, 1990.

BAK, L.S.; ANDERSEN, A.B.; ANDERSEN, E.M.; BERTELSEN, G. Effect of modified atmosphere packaging on oxidative changes in frozen cold water shrimp (Pandalus borealis). Food Chemistry, v.64, n.2, p.169-175, 1999.

BANKS, H.; RANZELL, N.; FINNE, G. Shelf-life studies on carbon dioxide finfish from the Gulf of Mexico. Journal of Food Science, v.45, n.2, p.157-162, 1980. 
BARNETT, H.J.; CONRAD, J.W.; NELSON, R.W. Use of laminated high and low density polyethylene flexive packaging to store trout in a modified atmosphere. Journal of Food Protection, v.50, n.8, p.645-651, 1987.

BARNETT, H.J.; STONE, F.E.; ROBERTS, G.C.; HUNTER, P.J.; NELSON, R.W.; KWOK, J.A study in the use of high concentration of $\mathrm{CO}_{2}$ in a modified atmosphere to preserve fresh salmon. Marine Fish Review, v.44, n.3, p.7-11, 1982.

BEIRÃO, L.H.; TEIXEIRA, E.; MEINERT, E.M. et al. Processamento e industrialização de moluscos. In: SEMINÁRIO E WORKSHOP “TENOLOGIA PARA APROVEITAMENTO INTEGRAL DO PESCADO”. Campinas, 2000. Resumos. Campinas: ITAL, 2000. p.38-84.

BELTRÁN, A.; MORAL, A. Changes in fatty acid composition of fresh and frozen sardine (Sardina pilchardus W.) during smoking. Food Chemistry, v.42, n.1, p.99109, 1992.

BERAQUET, N.J.; LINDO, M.M.K. Transformações bioquímicas "post mortem” em pescado. Boletim do Instituto de Tecnologia de Alimentos, v.22, n.2, p.169-192, 1985.

BLISCKSTAD, E.; ENFORS, S.O.; MOLIN, G. Effect of hyperbaric carbon dioxide pressure on the microbial flora of pork stored at $4^{\circ} \mathrm{C}$ or $14^{\circ} \mathrm{C}$. Journal Applied Bacteriology, v.50, n.3, p.493-504, 1981.

BOKNAES, N.; ØSTERBERG, C.; NILSEN, J.; DALGAARD, P. Influence of freshness and frozen storage temperature on quality of thawed cod fillets stored in modified atmosphere packaging. Lebensmittel - Wissenschaft und - Technologie, v.33, n.3, p.244-248, 2000. 
BOKNAES, N.; ØSTERBERG, C.; SØRENSEN, R,; NILSEN, J.; DALGAARD, P. Effects of technological parameters and fishing ground on quality attributes of thawed, chilled cod fillets stored in modified atmosphere packaging. Lebensmittel Wissenschaft und - Technologie, v.34, n.8, p.513-520, 2001.

BOSKOU, G.; DEBEVERE, J. In vitro study TMAO reduction by Shewanella putrefaciens isolated from cod fillets packed in modified atmosphere. Food Additives and Contaminants, v.15, n.2, p.229-236, 1998.

BOSKOU, G.; DEBEVERE, J. Reduction of trimethylamine oxide by Shewanella spp. under modified atmospheres in vitro. Food Microbiology, v.14, n.6, p.543-553, 1997.

BOSKOU, G.; DEBEVERE, J. Shelf-life extension of cod fillets with acetate buffer spray prior to packaging under modified atmospheres. Food Additives and Contaminants, v.17, n.1, p.17-25, 2000.

BRAGA, S.P.; GOMES, F.S.P.; SILVA, C.A.; SOUZA, S.E.L.; SOUSA, S.; SOUSA, C.P. In: CONGRESSO BRASILEIRO DE CIÊNCIA E TECNOLOGIA DE ALIMENTOS, 17., Fortaleza, 2000. Resumos. Fortaleza: SBCTA, 2000. v.1, p.4.80.

BRASIL. Ministério da Agricultura e do Abastecimento. Setor pesqueiro. http://www.setorpesqueiro.com.br/ministerios/ministerio_da_agricultura_e_do_abas tecimento/dpa/cadeias_produtivas/tilapia/prod_brasileira.shtm (26 fev. 2002a)

BRASIL. Ministério da Agricultura, Pecuária e Abastecimento. Regulamento da inspeção industrial e sanitária de produtos de origem animal - RIISPOA. Pescados e derivados, C.7, seção 1. Brasília, 2001. http://www.agricultura.gov.br/sda (11 out. 2002b) 
BRASIL. Ministério da Saúde. Agência nacional de vigilância sanitária. Resolução RDC n⿳⺈ 12 de 02 de janeiro de 2001. In: ASSOCIAÇÃO BRASILEIRA DAS INDÚSTRIAS DE ALIMENTOS. Compêndio de legislação de alimentos. São Paulo: ABIA, 2001a. v.1/A.

BRASIL. Ministério da Saúde. Secretaria de vigilância sanitária. Decreto if 55871, de 26 de março de 1965. In: ASSOCIAÇÃO BRASILEIRA DAS INDÚSTRIAS DE ALIMENTOS. Compêndio de legislação de alimentos. São Paulo: ABIA, 2001b. v.1.

BRASIL. Ministério da Saúde. Secretaria de vigilância sanitária. Portaria if 451, de 19 de setembro de 1997. In: ASSOCIAÇÃO BRASILEIRA DAS INDÚSTRIAS DE ALIMENTOS. Compêndio de legislação de alimentos. São Paulo: ABIA, 1997. v.1A.

BRASIL. Ministério do Interior. Agência nacional de águas. Portaria if 0013, de 15 de janeiro de 1976. Diário Oficial. Brasília, 1976. http://www.ana.gov.br/instrumentos/enquadramento/legislação/portaria/mi13_76.htm (27 nov. 2002c)

BREMNER, H.A.; STATHAM, J.A. Effect of potassium sorbate on refrigerated storage of vacuum packed scallops. Journal of Food Science, v.48, n.4, p.1042-1047, 1983.

BROWN, W.D.; ALBRIGHT, M.; WATTS, D.A.; HEYER, B.; SPRUCE, B.; PRICE, R.J. Modified atmosphere storage of rockfish (Sebastes miniatus) and silver salmon (Oncorhynchus kisutch). Journal of Food Science, v.45, n.1, p.93-101, 1980.

CAI, P.; HARRISON, M.A.; HUANG, Y.W.; SILVA, J.L. Toxin production by Clostridium botulinum type $\mathrm{E}$ in packaged channel catfish. Journal of Food Protection, v.60, n.11, p.1358-1363, 1997. 
CALAND-NORONHA, M.C.; MORAIS, J.O. Aspectos da poluição marinha em frente ao município de Fortaleza. Arquivos de Ciências Marinhas, v.12, n.2, p.109-115, 1972.

CÂNDIDO, L.M.B; NOGUEIRA, A.K.; SGARBIERI, V. Propriedades funcionais de concentrados protéicos de pescado preparados por vários métodos. Brazilian Journal of Food Technology, v.1, n.1/2, p.77-89, 1998.

CANN, D.C.; SMITH G. L.; HUSTON, N.C. Further studies on marine fish stored under modified atmosphere packaging. Aberdeen: Torry Reasearch Station, 1983. $61 \mathrm{p}$.

CHAMBERS IV, E.; ROBEL, A. Sensory characteristics of selected species of freshwater fish in retail distribuition. Journal of Food Science, v.58, n.3, p.508$512,1993$.

CHURCH, I.J.; PARSONS, A.L. Modified atmosphere packaging technology: a review. Journal of the Science of Food and Agriculture, v.67, n.2, p.143-152, 1995.

CHURCH, N. Map fish and crustaceans - sensory enhancement. Food Science and Technology Today, v.12, n.2, p.73-83, 1998.

COBB III, B.F.; VANDERZANT, C.; HYDER, K. Effect of ice storage upon free aminoacids content of tails of white shrimp. Journal Agriculture and Food Chemistry, v.22, n.6, p.1052-1055. 1974.

COCHRAN, W.G.; COX, G.M. Experimental designs. 2.ed. New York: John Wiley \& Sons, 1964. 611p. 
CONTRERAS-GUZMÁN, E. Bioquímica de pescados e derivados. Jaboticabal: FUNEP, 1994. 409p.

COYNE, F.P. The effect of carbon dioxide on bacterial growth with special reference to the preservation of fish. Part II. Gas storage of fresh fish. Journal Society Chemical Industry, v.52, p.19-24, 1933a.

COYNE, F.P. The effect of carbon dioxide on bacterial growth. Royal Society Proceedings, v.113, p.196-217, 1933b. Series B.

DALGAARD, P.; GRAM, L.; HUSS, H.H. Spoilage and shelf-life of cod fillets packed in vacuum or modified atmospheres. International Journal of Food Microbiology, v.19, n.3, p.283-294, 1993.

DALGAARD, P.; MEJIHOLM, O.; CHRISTIANSEN, T.J.; HUSS, H.H. Importance of Photobacterium phosphoreum in relation to spoilage of modified atmosphere-packed fish products. Letters in Applied Microbiology, v.24, n.5, p.373-378, 1997.

DALGAARD, P.; MUNOZ, L.G.; MEJIHOLM, O. Specific inhibition of Photobacterium phosphoreum extends the shelf life of modified-atmosphere-packed cod fillets. Journal of Food Protection, v.61, n.9, p.1191-1194, 1998.

DALGAARD, P. Qualitative and quantitative characterization of spoilage bacteria from packed fish. International Journal of Food Microbiology, v.26, n.3, p.319-333, 1995.

DANIELS, J.A., KRISHNAMURTHI, R.; RIZVI, S.H. A review of the effects of carbon dioxide on microbial growth and food quality. Journal of Food Protection, v.48, n.6, p.532-537, 1985. 
DANIELS, J.A., KRISHNAMURTHI, R.; RIZVI, S.H. Effects of carbonic acid dips and packaging on the shelf-life of fresh fish fillets. Journal of Food Science, v.51, n.4, p.929-931, 1986.

DASSO, I. Qué ponemos en juego al degustar un alimento? La Alimentación Latinoamericana, v.33, p.34-36, 1999.

DAVIS, A.R.; SLADE, A. Fate Aeromonas and Yersinia on modified-atmospherepackaged (MAP) cod and trout. Letters in Applied Microbiology, v.21, n.6, p.354$358,1995$.

DAVIS, H.K. Modified atmosphere packaging (MAP) of fish and seafood products. In: MODIFIED ATMOSPHERE PACKAGING (MAP) AND RELATED TECHNOLOGIES, Gloucestershire, 1995. Proceedings. Gloucestershire: Campden and Chorleywood Food Research Association, 1995. p.1-13.

DEBEVERE, J.; BOSKOU, G. Effect of modified atmosphere packaging on the TVB/TMA-producing microflora of cod fillets. International Journal of Food Microbiology, v.31, n.1/3, p.221-229, 1996.

DEBEVERE ,J.M.; VOETS, J.P. Influence of some preservatives on the quality of prepacked cod fillets in relation to the oxygen permeability of the film. Journal of Applied Bacteriology, v.35, p.351-356, 1972.

DE KONING, J.A.; MOL, H.T. Rates of free fatty acid formation from phospholipids and neutral lipids in frozen cape hake (Merluccius spp) mince at various temperatures. Journal of the Science of Food and Agriculture, v.50, n.3, p.391398, 1990. 
DHANANJAYA, S.; STROUD, G.D. Chemical and sensory changes in haddock and herring stored under modified atmosphere. International Journal of Food Science and Technology, v.29, n.5, p.575-583, 1994.

DODDS, K.L. Clostridium botulinum in foods. In: HAUSCHILD, A.H.W.; DODDS, K.L. (Ed.). Ecology and control in foods. New York: Marcel Dekker, 1993. p.5368.

DORSA, W.J.; MARSHALL, D.L.; MODDY, M.W.; HACKNEY, C.R. Low temperature growth and thermal inactivation of Listeria monocytogenes in precooked crawfish tail meat. Journal of Food Protection, v.56, n.2, p.106-109, 1993.

DUNAJSKI, E. Texture of fish muscle. Journal of Texture Studies, v.10, n.4, p.301$318,1979$.

DUTCOSKY, S.D. Análise sensorial de alimentos. Curitiba: Champagnat, 1996. 123p.

EINARSSON, H.; VALDIMARSSON, G. Bulk storage of iced fish in modified atmosphere. World Fishing, v.1, n.1, p.7-8, 1991.

EKLUND, T.; JARMUND, T. Microculture model studies on the effect of various gas atmospheres on microbial growth at different temperatures. Journal Applied Bacteriology, v.55, n.1, p.119-125, 1983.

ELlIOTT, P.H., STRAKA, R.P.; GARIBALDI, J.A. Polyphosphate inhibition of growth of pseudomonads from poultry meat. Journal Applied Microbiology, v.12, p.517-521, 1964. 
ENFORS, S.O.; MOLIN, G. The influence of high concentrations of $\mathrm{CO}_{2}$ on the germination of bacterial spores. Journal Applied Bacteriology, v.45, n.2, p.279$285,1978$.

ENFORS, S.O.; MOLIN, G. The influence of temperature on the growth inhibitory effect of carbon dioxide on Pseudomonas fragi and Bacillus cereus. Canadian Journal Microbiology, v.27, n.1, p.15-19, 1981.

FARBER, J.M. Microbiological aspects of modified-atmosphere packaging technology - a review. Journal of Food Protection, v.54, n.1, p.58-70, 1991.

FERNÁNDEZ ÁLVAREZ, M. Revisión: envasado activo de los alimentos. Food of the Science and Technology International, v.6, n.2, p.97-108, 2000.

FERREIRA, S.O. Aplicação de tecnologia à espécies de pescados de água doce visando atender a agroindústria rural. Piracicaba, 1987. 122p. Dissertação (M.S.) - Escola Superior de Agricultura “Luiz de Queiroz”, Universidade de São Paulo.

FEY, M.S.; REGENSTEIN, J.M. Extending shelf-life of fresh wet red hake and salmon using $\mathrm{CO}_{2}-\mathrm{O}_{2}$ modified atmosphere and potassium sorbate ice at $1^{\circ} \mathrm{C}$. Journal of Food Science, v.47, n.1, p.1048-1054, 1982.

FIRESTONE, D. Official methods and recommended practices of the American Oil Chemists Society. 5.ed. Champaign: AOCS, 1998. v.2.

FLETCHER, G.C.; MURRELL, W.G.; STATHAM, J.A.; STEWARD, B.J.; BREMNER, H.A. Packaging of scallops with sorbato: an assessment of the hazard from Clostridium botulinum. Journal of Food Science, v.53, n.2, p.349-352/358, 1988. 
FORREST, J.C.; ABERLE, E.D.; HENDRICK, H.B.; JUDGE, M.D.; MERKEL, R.A. Properties of fresh meat. In: FORREST, J.C.; ABERLE, E.D.; HENDRICK, H.B.; JUDGE, M.D.; MERCKEL, R.A. (Ed.). Principles of meat science. San Francisco: W.H. Freeman, 1975. p.174-189.

FREITAS, J.V.F.; GURGEL, J.J.S. Estudos experimentais sobre a conservação da tilápia do Nilo, Oreochromis niloticus (L., 1766) Trewavas, armazenada no gelo. Boletim Técnico do Departamento Nacional de Obras Contra a Seca, v.42, n.2, p.153-178, 1984.

FROST, W.H. Confirmatory tests for E. coli in routine water examinations. American Journal of Public Health, v.6, n.6, p.585-588, 1916.

GARCIA, G.W.; GENIGEORGIS, C.; LINDROTH, S. Risk of growth and toxin production by Clostridium botulinum nonproteolytic types B, E, and F in salmon fillets stored under modified atmospheres at low and abused temperatures. Journal of Food Protection, v.50, n.4, p.330-336, 1987.

GEIGER, E. Fish protein-nutritive aspects. In: BORGSTRON, G. (Ed.). Fish as food. New York: Academic Press, 1962. v.2, p.29-114.

GENIGEORGIS, C.A. Microbial and safety implications of the use of modified atmospheres to extend the storage life of fresh meat and fish. International Journal Food Microbiology, v.1, n.3, p.237-251, 1985.

GERMANO, P.M.L.; GERMANO, M.I.S.; OLIVEIRA, C.A.F. Aspectos da qualidade do pescado de relevância em saúde pública. Higiene Alimentar, v.12, n.53, 1998. p.30-37. 
GIBSON, A.M.; ELLIS-BROWNLEE, R.C.L.; CAHILL, M.E.; SZABO, E.A.; FLETCHER, G.C.; BREMER, P.J. The effect of $100 \% \mathrm{CO}_{2}$ on the growth of nonproteolytic Clostridium botulinum at chill temperatures. International Journal of Food Microbiology, v.54, n.1/2, p.39-48, 2000.

GÓES, J.A.W. Efeito do atraso no resfriamento sobre a carscterização da qualidade da tilápia (Oreochromis niloticus) conservada com gelo. Lavras, 1987. 118p. Dissertação (M.S.) - Escola Superior de Agricultura de Lavras.

GRAM, L.; HUSS, H.H. Microbiological spoilage of fish and fish products. International Journal of Food Microbiology, v.33, n.1, p.121-137, 1996.

GRAY, R.J.H.; HOOVEE, D.G.; MUIR, A.M. Attenuation of microbial growth on modified atmosphere-packaged fish. Journal of Food Protection, v.46, n.7, p.610613, 1983.

GUIDELINES for the handling of fish packed in a controlled atmosphere. Edinburgh: Sea Fish Industry Authority, 1985. p.52-53.

GUPTA, S.S.; BASU, S.; RAO, C.C.P.; CHAKRABORTI, R. Preservation of mullets in $\mathrm{CO}_{2}$ enriched gas-mixture at $67^{\circ} \mathrm{C}$. Fishery Technology, v.28, n.2, p.125-127, 1991.

HAARD, N.F. Control of chemical composition and food quality attributes of cultured fish. Food Research International, v.25, n.4, p.289-307, 1992.

HAARD, N.F.; LEE, Y.Z. Hypobaric storage of Atlantic salmon in a carbon dioxide atmosphere. Canadian Institute Food Science and Technology Journal, v.15, n.1, p.68, 1982. 
HACKNEY, C.R.; DICHARRY, A. Seafood-borne bacterial pathogens of marine origin. Food Technology, v.42, n.3, p.104-109, 1988.

HAINES, R.B. The influence of carbon dioxide on the rate of multiplication of certain bacteria as judged by viable counts. Journal Society Chemical Industry, v.52, p.13T-15T, 1933.

HAMILTON, M.; BENNETT, R. An investigation into consumer preferences for nine fresh white fish species and the sensory attributes which determine acceptability. Journal Food Technology, v.18, n.1, p.75-84, 1983.

HANSEN, P.; JORGENSEN, B.V. Storage life of vacuum-packed iced trout. I.: influence of packing material. Journal of the Science of Food and Agriculture, v.16, p.150-152, 1965.

HARRISON, M.A.; HUANG, Y.W.; CHAO, C.H.; SHINEMAN, T. Fate of Listeria monocytogenes on packaged, refrigerated, and frozen seafood. Journal of Food Protection, v.54, n.7, p.524-527, 1991.

HINTLIAN, C.B.; HOTCHKISS, J.H. Comparative growth of spoilage and pathogenic organisms in modified atmosphere-packaged cooked beef. Journal of Food Protection, v.50, n.3, p.218-223, 1987.

HINTLIAN, C.B.; HOTCHKISS, J.H. The safety of modified atmosphere packaging: A review. Journal Food Technology, v.40, n.12, p.70-76, 1986.

HOLLAND, G.C. Modified atmospheres for fresh meat distribution. Meat Industry Research, v.1, n.1, p.21-39, 1980. 
HONG, L.C.; LEBLANC, E.L.; HAWRYSH, Z.J.; HARDIN, R.T. Quality of Allantic mackerel (Scomber scombrus L.) fillets during modified atmosphere storage. Journal of Food Science, v.61, n.3, p.646-651, 1996.

HUANG, Y.; KOUADIO, K.; GATES, K.W. Microbiological, sensorial and chemical assessment of pre-packaged weakfish during iced storage. Journal of Aquatic Food Product Technology, v.2, n.1, p.135-145, 1993.

HULTIN, H.O. Oxidation of lipids in seafoods. In: SHAHIDI, F.; BOTTA, J.R. (Ed.). Seafoods: chemistry, processing, tecnology and quality. New York: Blackie Academic \& Professional, 1994. p.49-74.

HURTADO, J.L.; MONTERO, P.; BORDERÍAS, A.J. Extension of shelf life of chilled hake (Merluccius capensis) by high pressure. Food Science and Technology International, v.6, n.3, p.243-249, 2000.

HUSS, H.H. Prepackaged fresh fish. In: KREUZER, R. (Ed.). Fish inspection and quality control. London: Fishing News (Books) Limited, 1971. p.60-65.

INGHAM, S.C; POTTER, N.N. Growth of Aeromonas hydrophila and Pseudomonas fragi on mince and surimis made from Atlantic Pollock and stored air or modified atmosphere. Journal of Food Protection, v.51, n.12, p.966-970, 1988.

INTERNATIONAL COMMISSION ON MICROBIOLOGICAL SPECIFICATIONS FOR FOODS - ICMSF. APPCC na qualidade e segurança microbiológica de alimentos: análises de perigos e pontos críticos de controle para garantir a qualidade e segurança microbiológica de alimentos. São Paulo: Varela, 1987. p.377.

JAY, J.M. Modern food microbiology. 3.ed. New York: Van Nostrand Reinhold, 1986. 642p. 
JHAVERI, S.N.; CONSTANTINIDES, S.M. Chemical composition and shelf-life study of grayfish (Squalus arcanthias). Journal of Food Science, v.47, n.1, p.188-192, 1982.

JOSE, V.F. Bivalves e a segurança do consumidor. São Paulo, 1996. 182p. Dissertação (M.S.) - Instituto Oceanográfico, Universidade de São Paulo.

KABARA, J.J.; EKLUND, T. Organic acids and esters. In: RUSSEL, N.J.; WOULD, G.W. (Ed.). Food preservatives. Lodon: Blackie Academic \& Professional, 1991. p.44-71.

KANNER, J. Oxidative process in meat and meat products: quality implications. Meat Science, v.36, n.1/2, p.169-189, 1994.

KAREL, M.; SCHAICH, K.; ROY, R.B. Interation of peroxidizing methyl linoleate with some proteins and amino acids. Journal Agriculture and Food Chemistry, v.23, n.2, p.159-163, 1975.

KE, P.J.; CERVANTES, E.; ROBLES-MARTINEZ, C. Determination of thiobarbituric acid reactive substances (TBARS) in fish tissue by an improved distillationspectrophotometric method. Journal of the Science of Food and Agriculture, v.35, p.1248-1254, 1984.

KHALIL, A.H.; MANSOUR, E.H. Control of lipid oxidation in cooked and uncooked refrigerated carp fillets by antioxidant and packaging combinations. Journal Agricultural and Food Chemistry, v.46, n.3, p.1158-1162, 1998.

KHAYAT, A.; SCHWALL, D. Lipid oxidation in seafood. Food Technology, v.37, n.7, p.130-140, 1983. 
KING, A.D.; NAGEL, C.W. Growth inhibition of a Pseudomonas by carbon dioxide. Journal of Food Science, v.32, p.575-579, 1967.

KIRSCHNIK, P.G.; CARVALHO, M.R.B.; MACEDO-VIEGAS, E.M.; AIURA, F.S.; LIMA, T.M.A. Efeito das condições de abate e da temperatura de estocagem sobre as alterações pós-morte de tilápia do Nilo (Oreochromis niloticus). In: CONGRESSO BRASILEIRO DE CIÊNCIA E TECNOLOGIA DE ALIMENTOS, 17., Fortaleza, 2000. Resumos. Fortaleza: SBCTA, 2000. v.1, p.3.150.

KITAHARA, S.E.; OKADA, I.A.; SAKUMA, A.M.; ZENEBON, O.; JESUS, R.S.; TENUTA-FILHO, A. mercúrio total em pescado de água-doce. In: CONGRESSO BRASILEIRO DE CIÊNCIA E TECNOLOGIA DE ALIMENTOS, 17., Fortaleza, 2000. Resumos. Fortaleza: SBCTA, 2000. v.2, p.5.29.

KOSAK, P.H.; TOLEDO, R.T. Effects of microbiological decontamination on the storage stability of fresh fish. Journal of Food Science, v.46, n.4, p.1012-1014, 1981.

KROLOW, A.C.R.; MIGUENS, F.P.; GULARTE, M.; POUEY, J.L.O.F.; BANDEIRA, F.S.; ANTONIOLLO, P.C.; SILVA, W.P. Qualidade higiênica de lingüiça calabresa fresca elaborada a partir de filés de carpa húngara (Cyprinus carpio) submetida ou não à depuração. In: CONGRESSO BRASILEIRO DE CIÊNCIA E TECNOLOGIA DE ALIMENTOS, 17., Fortaleza, 2000. Resumos. Fortaleza: SBCTA, 2000. v.1, p.4.71.

KUAYE, A.Y. Comparação dos métodos para determinação das bases nitrogenadas voláteis em pescado: parâmetros críticos e modificações. Campinas, 1982. 95p. Dissertação (M.S.) - Faculdade de Engenharia de Alimentos e Agrícola, Universidade Estadual de Campinas. 
KUBITZA, F. Tilápia: tecnologia e planejamento na produção comercial. São Paulo: Degaspari, 2000. 289p.

KUUSI, T.; NIKKILA, O.E.; SAROLAINEN, K. Formation of malonaldeyde in fozen Baltic herring and its influence on changes in protein. Zeitschrift in Lebensmittel Untersuchun Undforschung, v.159, n.5, p.285, 1975.

LAHIRY, N.L.; MOORJANI, M.N.; BALIGA, B.R. Factors influencing the keeping quality of fres-water fish in ice. Food Technology, v.15, p.123-125, 1963.

LANNELONGUE, M.; FINE, G. Effect of carbon dioxide on growth-rates of selected microorganisms isolated from black drum (Pogonias cromis), Journal of Food Protection, v.49, n.10, p.806-810, 1986.

LANNELONGUE, M.; FINE, G.; HANNA, M.O.; NICKELSON, R.; VANDERZANT, G. Storage characteristics of brown shrimp (Peneaus aztecus) storage in retail packages containing $\mathrm{CO}_{2}$-enriched atmospheres. Journal of Food Science, v.47, n.3, p.911-913/923, 1982.

LEE, J.S. Selection and growth of seafood microorganisms under $\mathrm{CO}_{2}$ environment. In: MARTIN, R.E. (Ed.). In: NATIONAL CONFERENCE MODIFIED AND CONTROLLED ATMOSPHERE PACKAGING OF SEAFOOD PRODUCTS, 1., Washington, 1981. Proceedings. Washington: National Fisheries Institute, 1981. p.59.

LEISTNER, L. Food preservation by combined methods. Food Research International, v.25, n.2, p.151-158, 1992.

LEITÃO, M.F. de F. Microbiologia do pescado e controle sanitário no processamento. Boletim do Instituto de Tecnologia de Alimentos, v.14, n.50, p.1-35, 1977. 
LEITÃO, M.F. de F. Microbiologia e deterioração do pescado fresco e refrigerado de origem fluvial e marinha. In: SEMINÁRIO SOBRE CONTROLE DE QUALIDADE DO PESCADO. Santos, 1988. Anais. Santos: Editora Leopoldina/Edições Loyola, 1988. p.40-58.

LEITÃO, M.F.F.; TEIXEIRA FILHO, A.R.; BALDINI, V.L.S. Microbiota bacteriana em espécies de peixes fluviais e lacustres no Estado de São Paulo. Coletânea do Instituto de Tecnologia de Alimentos, v.15, n.1, p.91-111, 1985.

LERKE, P.; FARBER, L Heat pasteurization of crab and shrimp from the Pacific coast of the United States: public health aspects. Journal of Food Science, v.36, n.1, p.277-279, 1971.

LEUNG, C.; HUANG, Y.; HARRISON, M.A. Fate of Listeria monocytogenes and Aeromonas hydrophila on packaged channel catfish fillets stored at $4 \mathrm{C}$. Journal of Food Protection, v.55, n.9, p.728-730, 1992.

LIMA, M.F.V.; ZAPATA, J.F.F. Efeito do ácido lático e do lactato de sódio sobre as características físicas, químicas e sensoriais de filés frescos de tilápia-do-nilo (Oreochromis niloticus). In: CONGRESSO BRASILEIRO DE CIÊNCIA E TECNOLOGIA DE AlimentOS, 16., Rio de Janeiro, 1998. Anais. Rio de Janeiro: SBCTA, 1998. p.739-742.

LIMA, M.F.V.; ZAPATA, J.F.F.; FIGUEIREDO, E.A.T. Ácido láctico e do lactato de sódio como agentes de conservação de filés frescos de tilápia (Oreochromis niloticus). In: CONGRESSO BRASILEIRO DE CIÊNCIA E TECNOLOGIA DE ALIMENTOS, 16., Rio de Janeiro, 1998. Anais. Rio de Janeiro: SBCTA, 1998. p.739-742. 
LIMA, M.G.; REIS, R.B. Incidência de Salmonella sp.: uma comparação entre amostras de pacu (Piaractus mesopotamicus) de rio e cultivado comercializadas no município de Cuiabá-MT. In: CONGRESSO BRASILEIRO DE CIÊNCIA E TECNOLOGIA DE ALIMENTOS, 17., Fortaleza, 2000. Resumos. Fortaleza: SBCTA, 2000. v.1, p.4.116.

LINDSAY, R. Controlled atmosphere packaging. In: ANNUAL INTERNATIONAL SEAFOOD CONFERENCE, 4., Munich, 1981. Proceedings. Munich: 1981. p.18-21.

LIN, W.F.; HUANG, T.S.; CORNELL, J.A.; LIN, C.M.; WEI, C.I. Bactericidal activity of aqueous chlorine and chlorine dioxide solutions in a fish model system. Journal of Food Science, v. 61, n.5, p.1030-1034, 1996.

LIOUTAS, T.S. Challenges of controlled and modified atmosphere packaging: a food company's perspective. Food Technology, v.42, n.9, p.78-86, 1988.

LISTON, J. Recent advances in the chemistry of iced fish spoilage In: MARTIN, R.E. (Ed.). Chemistry and biochemistry of marine food products. Wesport: AVI, 1982. p.27-37.

LISTON, J.; STANSBY, M.E. OLCOTT, H.J. Bacteriological and chemical basis for deteriorative changes. In: STANSBY, M.E. (Ed.). Industrial fishery technology: a survey of methods for domestic harvesting, preservation, and processing of fish used for food and for industrial products. New York: Reinhold, 1963. p.350-361.

LOAIZA, J.F.U. Avaliação físico-química, microbiológica e sensorial de carne de rã (Rana catesbeiana) estocada sob refrigeração e congelamento. Viçosa, 1996. 112p. Dissertação (M.S.) - Universidade Federal de Viçosa. 
LÓPEZ-GÁLVEZ, D.E.; HOZ, L. de la; BLANCO, M.; ORDÓÑEZ, J.A. Refrigerated storage $\left(2^{\circ} \mathrm{C}\right)$ of sole (Solea solea) fillets under $\mathrm{CO}_{2}$-enriched atmospheres. Journal Agricultural and Food Chemistry, v.46, n.3, p.1143-1149, 1998.

LÓPEZ-GÁLVEZ, D.E.; HOZ, L. de la; ORDÓÑEZ, J.A. Effect of carbon dioxide and oxigen enriched atmospheres on microbiological and chemical changes in refrigerated tuna (Thunnus alaluga) steaks. Journal Agricultural and Food Chemistry, v.43, n.2, p.483-490, 1995.

LOVSHIN, L.L.; CYRINO, P.E.P. Status of commercial fresh water fish culture in Brazil. In: SIMPÓSIO SOBRE MANEJO E NUTRIÇÃO DE PEIXES, 2., Piracicaba, 1998. Anais. Campinas: CBNA, 1998. p. 1-20.

LÜCK, E. Conservasión química de los alimentos. Zaragoza: Acribia, 1981. 237p.

LUZIA, L.A.; SAMPAIO, G.R.; CASTELLUCCI, M.N.; OKANI, E.T.; TORRES, E.A.F.S. Avaliação da peroxidação lipídica em cinco espécies populares de pescados. In: CONGRESSO BRASILEIRO DE CIÊNCIA E TECNOLOGIA DE ALIMENTOS, 17., Fortaleza, 2000. Resumos. Fortaleza: SBCTA, 2000. v.2, p.5.133.

LYVER, A.; SMITH, J.P.; TARTE, I.; AUSTIN, J.; BLANCHFIELD, B. Competitive inhibition of Clostridium botulinum type E by Bacillus species in a value-added seafood product packaged under modified atmospheres. Food Research International, v.31, n.4, p.311-319, 1998a.

LYVER, A.; SMITH, J.P.; TARTE, I.; FARBER, J.M.; NATTRESS, F.M. Challenge studies with Listeria monocytogenes in a value-added seafood product stored under modified atmospheres. Food Microbiology, v.15, n.4, p.379-389, 1998b. 
MACHADO, I.C. Alterações "post-mortem" no pescado. In: SIMPÓSIO SOBRE CONTROLE DE QUALIDADE MICROBIOLÓGICO, QUÍMICO, FÍSICO E ORGANOLÉPTICO DE PESCADO E DERIVADO, Campinas, 1994. Anais. Campinas: ITAL, 1994. p.1-10.

MAIA, E.L.; RODRIGUEZ-AMAYA, D.B. Avaliação de um método simples e econômico para a metilação de ácidos graxos com lipídeos de diversas espécies de peixes. Revista do Instituto Adolfo Lutz, v.53, n.1/2, p.27-35, 1993.

MAIA, E.L.; RODRIGUEZ-AMAYA, D.B.; FRANCO, M.R.B. Fatty acids of the total, neutral, and phospholipids of the Brazilian freshwater fish Prochilodus scrofa. Journal of Food Composition and Analysis, v.6, n.4, p.240-251, 1994.

MAIA, E.L.; OGAWA, M. Composição de aminoácidos de peixes de água doce. In: CONGRESSO BRASILEIRO DE CIÊNCIA E TECNOLOGIA DE ALIMENTOS, 17., Fortaleza, 2000. Resumos. Fortaleza: SBCTA, 2000. v.2, p.5.37.

MANTOVANI, D.M.B.; MORGANO, M.A.; DAMASCENO, C.F. Avaliação de contaminantes inorgânicos em peixes de água do Estado de São Paulo. In: CONGRESSO BRASILEIRO DE CIÊNCIA E TECNOLOGIA DE ALIMENTOS, 17., Fortaleza, 2000. Resumos. Fortaleza: SBCTA, 2000. v.4, p.3.29.

MANTHEY, M.; KARNOP, G.; REHBEIN, H. Quality changes of European catfish (Silurus glanis) from warm-water aquaculture during storage on ice. International Journal of Food Science and Technology, v.23, n.1, p.1-9, 1988.

MAREL, G.M.; LOGTESTEIN, J.G.; MOSSEL, D.A.A. Bacteriological quality of broiler carcasses as affected by in-plant lactic acid decontamination. International Journal of Food Microbiology, v.6, n.1, p.31-42, 1988. 
MARTIN, R.E.; GRAY, R.J.H.; PIERSON, M.O. Quality assessment of fresh fish and the role of the naturally occurring microflora. Food Technology, v.32, n.5, p.188198, 1978.

MATCHES, J.R.; LAYRISSE, M.E. Controlled atmosphere storage of spotted shrimp (Pandalus platyceros). Journal of Food Protection, v.48, n.8, p.709-711, 1985.

MAYER, B.K.; WARD, D.R. Microbiology of finfish and finfish processing. In: WARD, D.R.; HACKNEY, C.R. (Ed.). Microbiology of marine food products. New York: Von Nostrand Reinhold, 1991. p.3-17.

MILLER, S.A.; BROWN, W.D. Effectiveness of chlortetracycline in combination with potassium sorbate or tetrasodium ethylenediaminetetraacetate for preservation of vacuum packed rockfish fillets. Journal of Food Science, v.49, n.1, p.188-191, 1984.

MITSUDA, H.K.; NAKAJIMA, K.; MIZUNO, H.; KAWAI, F. Use of sodium chloride for extending the shelf-life of fish fillets. Journal of Food Science, v.45, n.3, p.661$665,1980$.

MOKHELE, K.; JOHNSON, A.R.; BARRET, E.; OGRYDZIAK, D.M. Microbiological analysis of rock cod (Sebastes spp) stored under elevated carbon dioxide atmospheres. Applied and Environmental Microbiology, v.45, n.3, p.878-883, 1983.

MOLIN, G.; STENSTRÖM, I. M.; TERNSTRÖM, A. The microbial flora of herring fillets after storage in carbon dioxide, nitrogen or air at $2^{\circ} \mathrm{C}$. Journal of Applied Bacteriology, v.55, n.1, p.49-56, 1983. 
MOLIN, G. The resistance to $\mathrm{CO}_{2}$ of some food related bacteria. European Journal Applied Microbiology Biotechnology, v.18, n.4, p.214-217, 1983.

MOLLE, F.; CADIER, E. Manual do pequeno açude. Recife: SUDENE/Orstom/Tapi, 1992. 523p.

MOORJANI, M.N.; BALIGA, B.R.; VILJAYRANGA, B. et al. Post-rigor changes in nitrogen distribution and texture of fish during storage in crushed ice. Food Technology, v.16, p.80-84, 1962.

MOREIRA, A.B.; VISENTAINER, J.V.; SOUZA, N.E. de; MATSUSHITA, M. Fatty acids profile and cholesterol contents of three Brazilian Brycon freshwater fishes. Journal of Food Composition and Analysis, v.14, n.6, p.565-574, 2001.

MORGA, A.A. Avaliação do índice de frescor da pescada foguete (Macrodon ancylodon) conservada em gelo. Campinas, 1975. 80p. Dissertação (M.S.) Faculdade de Tecnologia de Alimentos, Universidade Estadual de Campinas.

MUJICA, P.Y.C. Avaliação da qualidade organoléptica, química e microbiológica de tilápia-do-nilo (Oreochromis niloticus), mantida à temperatura ambiente e sob gelo. Viçosa, 1988. 75p. Dissertação (M.S.) - Universidade Federal de Viçosa.

MUJICA, P.Y.C. Vida útil do cação (Prionace glauca) armazenado sob refrigeração e otimização dos métodos microbiológicos e sensoriais de avaliação da qualidade. Campinas, 2000. 103p. Tese (Doutorado) - Faculdade de Engenharia de Alimentos, Universidade Estadual de Campinas.

NETTO, F.M. Modificações químicas, bioquímicas e sensoriais do híbrido de tilápia estocado em gelo. Campinas, 1984. 79p. Dissertação (M.S.) - Faculdade de Engenharia de Alimentos, Universidade Estadual de Campinas. 
NILSSON, L.; HUSS, H.H.; GRAM, L. Inhibition of Listeria monocytogenes on coldsmoked salmon by nisin and carbon dioxide atmosphere. International Journal of Food Microbiology, v.38, n.2/3, p.217-227, 1997.

OETTERER, M. Agroindústrias beneficiadoras de pescado cultivado: unidades modulares e polivalentes para implantação, com enfoque nos pontos críticos e higiênicos e nutricionais. Piracicaba, 1999. 198p. Tese (Livre-docente) - Escola Superior de Agricultura “Luiz de Queiroz”, Universidade de São Paulo.

OETTERER, M. Matéria-prima alimentar: pescado. São Caetano do Sul: Centro de Pesquisas do Instituto Mauá de Tecnologia, 1991. 29p.

OGAWA, M.; MAIA, E.L. Manual de pesca: ciência e tecnologia do pescado. São Paulo: Varela, 1999. v.1, 430p.

OGRYDZIAK, D.M.; BROWN, W.D. Temperature effects in modified-atmosphere storage of seafood. Food Technology, v.36, n.5, p.86-96, 1982.

ORDÓÑEZ, J.A.; LÓPEZ-GÁLVEZ, D.E.; FERNÁNDEZ, M.; HIERRO, E.; HOZ, L de la. Microbial and physicochemical modifications of hake (Merluccius merluccius) steaks stored under carbon dioxide enriched atmospheres. Journal of the Science of Food and Agriculture, v.80, n.13, p.1831-1840, 2000.

OZOGUL, F.; TAYLOR, K.D.A.; QUANTICK, P.; OZOGUL, Y. Chemical, microbiological and sensory evaluation of Atlantic herring (Clupea harengus) stored in ice, modified atmosphere and vacuum pack. Food Chemistry, v.71, n.2, p.267273, 2000. 
PALUDAN-MÜLLER, C.; DALGAARD, P.; HUSS, H.H.; GRAM, L. Evaluation of the role of Carnobacterium piscicola in spoilage of vacuum and modifiedatmosphere-packed cold-smoked salmon stored at $5^{\circ} \mathrm{C}$. International Journal of Food Microbiology, v.39, n.3, p.155-166, 1998.

PARDI, M.C.; SANTOS, I.F.; SOUZA, E.R.; PARDI, H.S. Ciência, higiene e tecnologia da carne: tecnologia da carne e subprodutos. Goiânia: CEGRAF/UFG, 1994. v.2, p.638-675.

PARKIN, K.L.; WELLS, M.J.; BROWN, W.D. Modified atmosphere storage of rockfish fillets. Journal of Food Science, v.47, n.1, p.181-184, 1981.

PARRY, R.T. (Ed.). Principles and applications of modified atmosphere packaging of food. London: Blackie, 1993. p.1-18.

PASSY, N.; MANNHEIM, C.H.; COHEN, D. Effect of modified atmosphere and pretreatments on quality of chilled fresh water prawns (Macrobrachium rosenbergii). Lebensmittel - Wissenschaft und - Technologie, v.16, n.3, p.224-229, 1983.

PASTORIZA, L.; SAMPEDRO, G.; HERRERA, J.J.; CABO, L.M. Effect of carbon dioxide atmosphere on microbial growth and quality of salmon slices. Journal of the Science of Food and Agriculture, v.72, n.3, p.348-352, 1996a.

PASTORIZA, L.; SAMPEDRO, G.; HERRERA, J.J.; CABO, L.M. Effect of modified atmosphere on shelf-life of iced fresh hake slices. Journal of the Science of Food and Agriculture, v.71, n.5, p.541-547, 1996 b. 
PASTORIZA, L.; SAMPEDRO, G.; HERRERA, J.J.; CABO, L.M. Influence of sodium chloride and modified atmosphere packaging on microbiological, chemical and sensorial properties in ice storage of slices of hake (Merluccius merluccius). Food Chemistry, v.61, n.1/2, p.23-28, 1998.

PEDROSA-MENABRITO, A.; REGENSTEIN, J.M. Shelf-life extension of fresh fish. A review. Spoilage of fish. Journal of Food Quality, v.2, n.2, p.117-127, 1988.

POST, L.S.; LEE, D.A.; SOLBERG, M.; FURGANG, D.; SPECCHIO, J.; GRAHAM, C. Development of botulinal toxin and sensory deterioration during storage of vacuum and modified atmosphere packaged fish fillets. Journal of Food Science, v.50, n.4, p.990-996, 1985.

PRENTICE, C.; SAINZ, R. Desenvolvimento de um produto minimamente processado a base de carpa-capim (Ctenopharyngodon idella). In: CONGRESSO BRASILEIRO DE CIÊNCIA E TECNOLOGIA DE ALIMENTOS, 17., Fortaleza, 2000. Resumos. Fortaleza: SBCTA, 2000. v.3, p.11.116.

PRZYBYLSKI, L.A.; FINERTY, M.W.; GRODNER, R.M.; GERDES, D.L. Extension of shelf life of iced fresh channel catfish fillets using modified atmospheric packaging and low dose irradiation. Journal of Food Science, v.54, n.2, p.269-273, 1989.

RAHMAN, S.A.; HUAH, T.S.; HASSAN, O.; DAUD, N.M. Fatty acid composition of some Malaysian freswater fish. Food Chemistry, v.54, v.1, p.45-49, 1995.

RANDELL, K.; AHVENAINEN, R.; HATTULA, T. Effect of gas/product ratio and $\mathrm{CO}_{2}$ concentration on the shelf life of MA packed fish. Packaging Technology \& Science, v.8, p.205-218, 1995. 
RANDELL, K.; HATTULA, T.; AHVENAINEN, R. Effect of packaging method on the quality of rainbow trout and baltic herring fillets. Lebensmittel-Wissenschaft und - Technologie, v.30, n.1, p.56-61, 1997.

RANDELl, K.; HATTULA, T.; SKYTTÃ, E.; SIVERTSVIK, M.; BERGSLIEN, H.; AHVENAINEN, R. Quality of filleted salmon in various retail packages. Journal of Food Quality, v.22, p.485-497, 1999.

REDDY, N.R.; ARMSTRONG, D.J.; RHODEHAMEL, E.J.; KAUTER, D.A. Shelf-life extension and safety concerns about fresh fishery products packaged under modified atmospheres: a review. Journal of Food Safety, v.12, p.87-118, 1992.

REDDY, N.R.; PARADIS, A.; ROMAN, M.G.; SOLOMON, H.M.; RHODEHAMEL, E.J. Toxin development by Clostridium botulinum in modified atmospherepackaged fresh tilapia fillets during storage. Journal of Food Science, v.61, n.3, p.632-635, 1996.

REDDY, N.R.; ROMAN, M.G.; VILLANUEVA, M.; SOLOMON, H.M.; KAUTER, D.A.; RHODEHAMEL, E.J. Shelf life and Clostridium botulinum toxin development during storage of modified atmosphere-packaged fresh catfish fillets. Journal of Food Science, v.62, n.4, p.878-884, 1997a.

REDDY, N.R.; SCHREIDER, C.L.; BUZARD, K.S.; SKINNER, G.E.; ARMSTRONG, D.J. Shelf life of fresh tilapia fillets packaged in high barrier film with modified atmospheres. Journal of Food Science, v.59, n.2, p.260-264, 1994.

REDDY, N.R.; SOLOMON, H.M.; YEP, H.; ROMAN, M.G.; RHODEHAMEL, E.J. Shelf life and toxin development by Clostridium botulinum during storage of modified atmosphere-packaged fresh aquacultured salmon fillets. Journal of Food Protection, v.60, n.9, p.1055-1063, 1997b. 
REDDY, N.R.; VILLANUEVA, M.; KAUTTER, D.A. Shelf life of modifiedatmosphere-packaged fresh tilapia fillets stored under refrigeration and temperatureabuse conditions. Journal of Food Protection, v.58, n.8, p.908-914, 1995.

REGENSTEIN, J.M. The shelf-life extension of haddock in $\mathrm{CO}_{2}$ atmospheres with and without potassium sorbate. Journal of Food Quality, v.5, p.285-300, 1982.

REILLY, J.A.; BARILE, L.E. Depuration of farmed bivalves in the Philippines. Infofish Marketing Digest, v.4, p.44-46, 1987.

ROSS, D.A.; LOVE, R.M. Decrease in the cold store flavour developed by frozen fillets of starved cod (Gadus morhua L.). Journal of Food Technology, v.14, n.2, p.115$122,1979$.

RUIVO, E.U. A análise sensorial na avaliação da qualidade do pescado. In: SEMINÁRIO SOBRE CONTROLE DE QUALIDADE DO PESCADO. Santos, 1988. Anais. Santos: Editora Leopoldina/ Edições Loyola, 1988. p.69-80.

RUIZ-CAPILLAS, C.; MORAL, A. Chilled bulk storage of gutted hake (Merluccius merluccius L.) in $\mathrm{CO}_{2}$ and $\mathrm{O}_{2}$ enriched controlled atmospheres. Food Chemistry, v.74, n.3, p.317-325, 2001.

SAS INSTITUTE. SAS user's guide: statistics (software). Version 8.0. Cary, 1999.

SATOH, S., TAKEUCHI, T., WATANABE, T. Effects of sarvation and environmental temperature on proximate and fatty acid composition of Tilapia nilotica. Bulletin of the Japonese Society of Sceintific Fisheries, v.50, p.79-84, 1984.

SAWYER, F.M.; CARDELlO, A.V.; PRELL, P.A. Consumer evaluation of the sensory properties of fish. Journal of Food Science, v.53, n.1, p.12-18/24, 1988. 
SCOTT, D.N.; FLETCHER, G.C.; HOGG, M.G. Storage of snapper fillets in modified atmospheres at $-1^{\circ} \mathrm{C}$. Food Technology Australia, v.38, p.234-238, 1986.

SGARBIERI, W.C. Proteínas em alimentos protéicos: propriedades, degradações, modificações. São Paulo: Varela, 1996. 516p.

SHARP, W.F. Jr.; NORBACH, J.P.; STUIBER, D.A. Using a new measure to define shelf life of fresh whitefish. Journal of Food Science, v.51, n.4, p.936-939, 959, 1986.

SHAW, S.J.; BLIGH, E.G.; WOYEWODA, A.D. Effect of potassium sorbate application on shelf life of Atlantic cod (Gadus morhua). Canadian Institute Food Science Technology, v.16, n.4, p.237-241, 1983.

SHEWAN, J.M. Food poisoning caused by fish and fishery products. In: BORGSTROM, G. (Ed.). Fish as food. New York: Academic Press, 1962. v.2, p.443-466.

SHEWAN, J.M. Improving the quality of white fish by the use of gas storage. s.n.t. 1950. p.1-14. (Fishing News, 1946)

SHEWAN, J.M. The bacteriology of fresh and spoiling fish and biochemical changes induced by bacterial action. In: CONFERENCE ON HANDLING, PROCESSING AND MARKETING OF TROPICAL FISH. London, 1977. Proceedings. London: Tropical Products Institute, 1977. p.51-66.

SIKORSKI, Z.E. Composición nutritiva de los principales grupos de organismos alimenticos marinos. Tecnología de los productos del mar: recursos. Zaragoza: Acribia, 1990. p.41-72. 
SIKORSKI, Z.E.; KOLAKOWSKA, A.; BURT, J.R. Cambios bioquimicos y microbianos subsiguientes a la captura. In: SIKORSKI, Z.E. (Ed.). Tecnología de los productos del mar: recursos, composition y conservation. Zaragoza: Acribia, 1994. cap.4, p.73-101.

SILLIKER, J.H.; WOLFE, S.K. Microbiological safety considerations in controlledatmosphere storage of meats. Food Technology, v.34, n.2, p.59-63, 1980.

SILVA, J.L.; HARKNESS, E.; WHITE, T.D. Residual effect of $\mathrm{CO}_{2}$ on bacterial counts and surface $\mathrm{pH}$ of channel catfish. Journal of Food Protection, v.56, n.12, p.10511053, 1993.

SILVA, J.L.; WHITE, T.D. Bacteriological and color changes in modified atmospherepackaged refrigerated channel catfish. Journal of Food Protection, v.57, n.8, p.715$719,1994$.

SILVA, N.; JUNQUEIRA, V.C.A.; SILVEIRA, N.F.A. Manual de métodos de análises microbiológicas de alimentos. São Paulo: Varela, 1997. 295p.

SIQUEIRA, A.A.Z.C. de. Efeitos da irradiação e refrigeração na qualidade e no valor nutritivo da tilápia (Oreochromis niloticus). Piracicaba, 2001. 137p. Dissertação (M.S.). Escola Superior de Agricultura "Luiz de Queiroz", Universidade de São Paulo.

SIVERTSVIK, M.; JEKSRUD, W.K.; ROSNES, J.T. A review of modified atmosphere packaging of fish and fishery products: significance of microbial growth, activities and safety. International Journal of Food Science and Technology, v.37, n.2, p.107-127, 2002. 
SIVERTSVIK, M.; ROSNES, J.T.; VORRE, A.; RANDELL, K.; AHVENAINEN, R.; BERGSLIEN, H. Quality of whole gutted salmon in various bulk packages. Journal of Food Quality, v.22, p.387-401, 1999.

SMITH, J.; SIMPSON, B.; LAMBERT, A. Use of modified atmospheres for shelf life extension of food. Food Science \& Technology Today, v.2, n.4, p.250-255, 1987.

SMULDERS, F.J.M.; WOOLTHUIS, G.H.J. Immediate and delayed microbiological effects of lactic acid decontamination of calf carcasses. Influence on conventionally boned versus hot boned and vacuum-packaged cuts. Journal of Food Protection, v.48, n.10, p.838-847, 1985.

SOCCOL, M.C.H.; BIATO, D.; OETTERER, M. A acidificação como complemento para extensão da vida útil de tilápias (Oreochromis niloticus) minimamente processadas (compact disc). In: CONGRESSO BRASILEIRO DE CIÊNCIA E TECNOlOGIA DE AlimEnTOS, 18., Porto Alegre, 2002. Anais. Porto Alegre: SBCTA, 2002. p.224-228.

SPACKMAN, D.C.; STEIN, W.H.; MOORE, S. Automatic recording apparatus for use in the chromatography of aminoacids. Analytical Biochemistry, v.30, p.1190-1206, 1958.

SPENCER, J.V.; SMITH, L.E. The effect of chilling chicken fryers in a solution of polyphosphates upon moisture uptake, microbial spoilage, tenderness, juiciness and flavor. Poultry Science, v.41, n.2, p.1685, 1962.

STAMMEN, K.; GERDES, D.; CAPORASO, F. Modified atmosphere packaging of seafood. CRC Critical Reviews in Food Science and Nutrition, v.29, n.5, p.301$331,1990$. 
STANSBY, M.E. Proximate composition of fish. In: HEEN E.; KREUZER R. (Ed.). Fish in nutrition. London: Fishing News Books Ltda, 1962. p.1-59.

STATHAM, J.A.; BREMNER, H.A.; QUARMBY, A.R. Storage of morwong (Nemadactylus macropterus Bloch and Schneider) in combinations of polyphosphate, potassium sorbate and carbon dioxide at ${ }^{\mathrm{P}} \mathrm{C}$. Journal of Food Science, v.50, n.6, p.1580-1584/1587, 1985.

STATHAM, J.A. Modified atmosphere storage of fisheries products: the state of the art. Food Technology Australia, v.36, n.5, p.233-239, 1984.

STEINER-ASIEDU, M.; JULSHAMN, K.; LIE, O. Effect of local processing methods (cooking, frying and smoking) on three fish species from Ghana: Part I. Proximate composition, fatty acids, minerals, trace elements and vitamins. Food Chemistry, v.40, n.3, p.309-321, 1991.

STENSTRÖM, I.M. Microbial flora of cod fillets (Gadus morhua) stored at $2^{\circ} \mathrm{C}$ in different mixtures of carbon dioxide and nitrogen/oxygen. Journal of Food Protection, v.48, n.7, p.585-589, 1985.

STIER, R.F.; BELL, L.; ITO, K.A.; SHAFER, B.D.; BROWN, L.A.; STEEGER, M.L.; ALLEN, B.H.; PORCUNA, M.N.; LERKE, P.A. Effect of modified atmosphere storage on Clostridium botulinum toxigenesis and the spoilage microflora of salmon fillets. Journal of Food Science, v.46, n.6, p.1639-1642, 1981.

TAKAMA, K. Insolubilization of rainboe trout actomyosin during storage at $-20^{\circ} \mathrm{C}$. II. Mechanism of propanal or caproic acid reaction with actomyosin to induce insolubilization. Bulletin of the Japonese Society of Sceintific Fisheries, v.40, n.6 p.589-593, 1974. 
TARLADGIS, B.G.; WATTS, B.M.; YOUNATHAN, M.T. A distillation method for the quantitative determination of malonaldehyde in rancid foods. The Journal of the American Oil Chemists Society, v.37, p.44-48, 1960.

TARR, H.L.A. Post mortem changes in glycogen, nucleotides sugar phosphates and sugar in fish muscles: a review. Journal of Food Science, v.31, p.846-858, 1966.

TAYLOR, S.L.; CANN, D.D.; WELCH, B.J. Antibotulinal properties of nisin in fresh fish packaged in an atmosphere of carbon dioxide. Journal of Food Protection, v.53, n.11, p.953-957, 1990.

TAYLOR, S.L. Marine toxins of microbial origin. Food Technology, v.42, n.3, p.3, 1988.

TAYLOR, S.L.; SUMNER, S.S. Determination of histamine, putrescina and cadaverina. In: KRAMER, D.E.; LISTON, J. (Ed.). Seafood quality determination. Amsterdam: Elsevier Science Publishers, 1987. p.235-245.

TELLES, F.J.S. Enterobactérias nas águas estuarinas do Rio Jaguaribe (Ceará). Arquivos de Ciências Marinhas, v.15, n.2, p.97-99, 1975.

VANDERZANT, C.; SPLITTSTOESSER, D.F. Compendium of methods for the microbiological examination of foods. 3.ed. Washington: American Public Health Association - APHA, 1992. cap.25, 1219p.

VAN NETTEN, P.; VAN DER ZEE, H.; MOSSEL, D.A.A. A note on catalaseenhanced recovery of acid injured cells of Gram negative bacteria and its consequences of the assessment of the lethality of 1-lactic acid decontamination of raw meat surfaces. Journal of Applied Bacteriology, v.57, n.1, p.169-173, 1984. 
VIEIRA, K.V.M.; MAIA, D.C.C.; JANEBRO, D.I.; VIEIRA, R.H.S.F.; CEBALLOS, B.S.O. Influência das condições higiênico-sanitárias no processo de beneficiamento de tilápias (Orechromis niloticus) em filés congelados. Higiene alimentar, v.14, n.74, p.37-40, 2000.

VIEIRA， R.H.S.F.; VIEIRA， G.H.F.; ROCHA， C.A.S.; SAKER-SAMPAIO， S.; SAMPAIO, A.H. Estudo organoléptico e bacteriológico de caudas de lagostas estocadas em gelo. Arquivos de Ciências Marinhas, v.23, n.1, p.63-75,1986.

VILLEMURE, G.; SIMARD, R.F.; PICARD, G. Bulk storage of cod fillets and gutted cod (Gadus morhua) under carbon dioxide atmosphere. Journal of Food Science, v.51, n.2, p.317-320, 1986.

VITALI, A. de A. Novas tendências em processamento de alimentos. Boletim da Sociedade Brasileira de Ciências e Tecnologia de Alimentos, v.31, n.1, p.15-16, 1997.

WAGNER, M.K.; BUSTA, F.F. Effect of sodium and pyrophosphate in combination with sodium nitrite or sodium nitrite/potassium sorbate on Clostridium botulinum growth and toxin production in beef/pork frankfurter emulsions. Journal of Food Science, v.48, n.3, p.991-993, 1983.

WANG, M.Y.; BROWN, W.D. Effects of elevated $\mathrm{CO}_{2}$ atmosphere on storage of freshwater crayfish (Pacifastacus leniusculus). Journal of Food Science, v.48, n.1, p.158-162, 1983.

WANG, M.Y.; OGRYDZIAK, D.M. Residual effect of storage in an elevated carbon dioxide atmosphere on the microbial flora of rock cod (Sebastes spp.). Applied and Environmental Microbiology, v.52, n.4, p.727-732, 1986. 
WARD, D.R. Microbiological quality of fishery products. In: MARTIN, A.M. (Ed.). Fisheries processing, biotechnological application. London: Chapman and Hall, 1994. cap.1, p.1-17.

WATTS, D.A.; BROWN, W.D. Histamine formation is abusively stored Pacific macharel: effect of $\mathrm{CO}_{2}$-modified atmosphere. Journal of Food Science, v.47, n.5, p.1386-1387, 1982.

WEI, C.I.; CHEN, C.M.; KOBURGER, J.A.; OTWELL, W.S.; MARSHALL, M.R. Bacterial growth and histamine production on vacuum packaged tuna. Journal of Food Science, v.55, n.1, p.59-63, 1990.

WESSON, J.B.; LINDSAY, R.C.; STUIBER, D.A. Discrimination of fish and seafood quality by consumer populations. Journal of Food Science, v.44, n.3, p.878-886, 891, 1979.

WILLIAMS, S.K.; RODRICK, G.E.; WEST, R.L. Sodium lactate affects shelf life and consumer acceptance of fresh catfish (Ictalurus nebulosus, marmoratus) fillets under simulated retail conditions. Journal of Food Science, v.60, n.3, p.636-639, 1995.

WINDSOR, M.L.; THOMA, T. Chemical preservation of industrial fish: new preservative mixtures. Journal of the Science of Food and Agriculture, v.25, n.2, p.993-1005, 1974.

WOLFE, S.K. Use of $\mathrm{CO}$ and $\mathrm{CO}_{2}$ enriched atmospheres for meats, fish and produce. Food Technology, v.34, n.2, p.55-58, 1980.

WOYEWODA, A.D.; BLIGH, E.G.; SHAW, S.J. Controlled and modified atmosphere storage of cod fillets. Canadian Institute Food Science and Technology, v.17, n.1, p.24-27, 1984. 
YEH, C.S.; NCKELSON II, R.; FINNE, G. Ammonia producing enzymes in white shrimp tails. Journal of Food Science, v.43, n.5, p.1400-1404, 1978.

ZOTTOLA, E. Introduction to meat microbiology. Washington: American Meat Institute, 1988. 1v. 